\title{
A Role for B-1 B cells and IgM antibodies in Obesity-Induced Glucose Intolerance and Insulin Resistance
}

\author{
Daniel Harmon \\ West Linn, OR
}

B.S. Rice University, 2007

A dissertation presented to the Graduate Faculty of the University of Virginia in Candidacy for the Degree of

Doctor of Philosophy

Department of Biochemistry, Molecular Biology, and Genetics

University of Virginia

May, 2014 


\section{ABSTRACT}

Obesity, characterized by an excess of adipose tissue, is a leading cause of metabolic disease. It is now well accepted that obesity-induced adipose tissue inflammation contributes to systemic insulin resistance and glucose intolerance that can lead to type 2 diabetes. B cells and their secreted antibodies have recently emerged as important regulators of adipose tissue inflammation and insulin resistance associated with obesity, but roles for specific B cell subsets are still unclear. The helix-loop-helix factor $l d 3$ mediates B cell function and obesity development, suggesting it may link B cells and metabolism. Here, we used a mouse containing a B cell-specific deletion of $I d 3\left(\mathrm{Id} 3^{\mathrm{Bcell}} \mathrm{KO}\right)$ to study the role B cells play in diet-induced adipose tissue inflammation and glucose intolerance. In addition, we assessed an obese human cohort for associations between adipose tissue B cells, natural IgM antibodies, and indices of inflammation and insulin resistance. Id $3^{\mathrm{Bcell}} \mathrm{KO}$ mice had increased numbers of visceral adipose tissue $\mathrm{B}-1 \mathrm{~b}$ B cells and attenuated high-fat diet (HFD)-induced glucose intolerance compared to littermates. Omental visceral fat from Id3 ${ }^{\mathrm{Bcell}} \mathrm{KO}$ mice displayed enhanced local natural IgM secretion. Furthermore, Id $3^{\mathrm{Bcell}} \mathrm{KO}$ mice fed a short-term HFD had less inflammation and improved insulin signaling in omental fat compared to controls. Transfer of B-1b B cells null for Id 3 was sufficient to attenuate diet-induced glucose intolerance in Rag1\% hosts, while B-1b B cells unable to secrete IgM had no effect. In humans, a recently identified $C D 20^{+} \mathrm{CD} 27^{+} \mathrm{CD} 43^{+} \mathrm{B}$ cell with $\mathrm{B}-1$-like characteristics was identified within omental fat, and correlated with serum natural IgM levels. In addition, IgM antibodies were inversely associated with the 
inflammatory chemokine MCP-1 and insulin resistance. Results presented here provide the first evidence that IgM antibody-producing B-1b B cells attenuate diet-induced glucose intolerance in mice. In addition, we link anti-inflammatory natural IgM antibodies with reduced inflammation and improved metabolic phenotype in obese humans. Together, these findings suggest role for B-1 B cells and natural IgM antibodies in mediated obesity associated metabolic dysfunction. 


\section{DEDICATION AND ACKNOWLEDGEMENTS}

I am grateful to the many people who have supported me throughout my graduate studies. First and foremost, I would like to thank my mentor, Dr. Coleen McNamara. In addition to the many laboratory skills I have learned while working in her lab, her support and guidance has provided me with scientific writing, speaking, and collaboration skills that will be invaluable as I begin my scientific career. From letting her students assist with grant and paper reviewing, to giving them opportunities to present their research to visiting scientists and to attend national conferences, Dr. McNamara provides a full scientific education that extends far beyond the bench. Most importantly, her fearless drive to "follow the science" has instilled in me the importance of stepping outside of my comfort zone to pursue the truly important scientific questions.

I would also like to thank the rest of the McNamara laboratory. While they have all been out of the lab for over a year, Alexis Cutchins, Jen Kirby, Mike Lipinski, Steph Oldham, and Marcus Skaflen made me feel welcome when I joined the lab, and were a great source of knowledge and technical assistance while I was getting my feet wet. I would especially like to thank Alexis for teaching me how to process adipose tissue and Steph for, among many other things, helping me with the numerous metabolic studies that I could not have possibly done on my own. Jim Garmey continues to be the keystone of the lab, and his technical assistance and ability to help out with an experiment on short notice has been greatly appreciated. During my time here, I have had the opportunity to work with several undergrad, medical, and rotating students that 
have passed through the lab. Liz Rose, Helen Hougen, Becky Wilson, and Jin Meng all contributed to this project and my development as a scientist in one way or another. I have also enjoyed working with Melissa Marshall and Chantel McSkimming - they both work extremely hard to make the lab run smoothly, and Chantel has been a tremendous flow cytometry resource. Lastly, I would like to thank the grad students of the McNamara lab. Heather Perry and I struggled to learn flow cytometry together, and she has been an invaluable resource my entire time in the lab. Heather, Sam Morris-Rosenfeld, and Jen Kaplan made coming to work fun, and I will really miss the fun we had at ATVB conferences, Thirsty Thursdays, and lunch at St. Maarten's.

Other people outside the McNamara lab also supported me throughout my time at UVA. Dr. Angela Taylor was extremely helpful with analysis of human data. Dr. Shayn Peirce-Cottler generously allowed me access to her lab's confocal microscope, and Scott Seaman donated multiple hours of his time teaching me how to use it. Dr. Loren Erickson was always willing to sit down and answer questions regarding B cell biology, and continues to be a valuable source of information. My other committee members, Drs. Patrick Grant, Marty Mayo, and Patrick Concannon were always able to provide helpful insight even when my project ventured out of their respective fields of expertise. I am especially grateful to Dr. Ron Taylor for agreeing to be a late addition to my committee - his suggestions and contributions to my last two committee meetings were very much appreciated. I would also like to thank Joanne Lannigan, Lesa Campbell, Mike Solga, and Sebastien Coquery. They help make the UVA flow cytometry 
core one of the best in the country and all were tremendous resources throughout my time here. A special thanks also goes out to Dr. Sam Tsimikas and his laboratory at UCSD for his help with some of the human antibody data acquisition and analysis.

None of this would be possible without the love and support of my family. My parents, Dave and Judi, have made endless sacrifices to provide me with the best opportunities to succeed. Their willingness to support me in everything that I do has shaped me, and I am incredibly grateful for all they have done for me. My brother, Joey, has also had a tremendous impact on my life. Whether it's a heartto-heart talk, playing Ping-Pong, or just having a fun night out, I always enjoy spending time with him. I would also like to thank my in-laws, Mike and Lannie Lark. Weekends at their house near Philadelphia were much-needed reprieves from the grind of grad school, and Mike continues to be a great resource for advice about research and future career options. Finally, my wife Sara has been my one constant through the good times and bad. She's always able to put me in a better mood after a long day and, most importantly, she pushes me to be better at everything I do. Her endless drive and passion inspires me, and I can't thank her enough for her support. 


\section{TABLE OF CONTENTS}

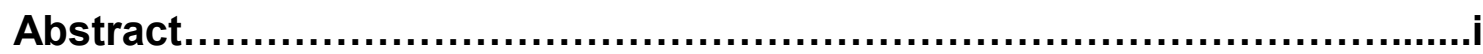

Dedication and Acknowledgements.............................................ii

Table of Contents........................................................................

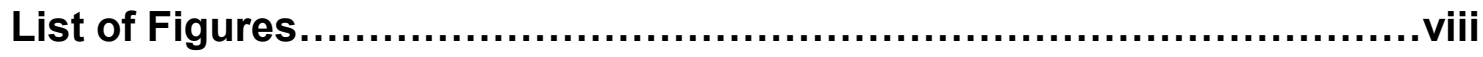

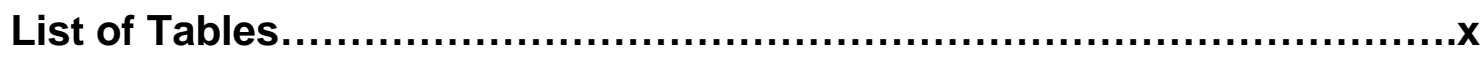

List of Abbreviations..............................................................

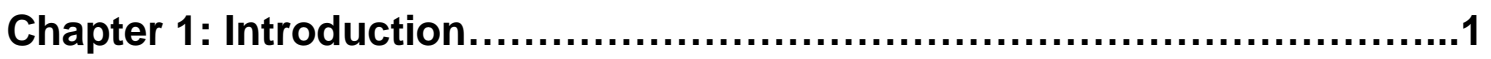

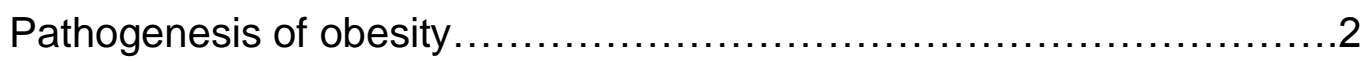

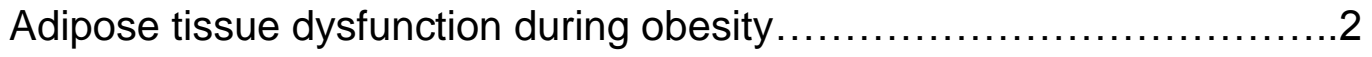

Adipose tissue distribution...........................................

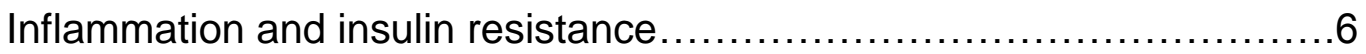

Macrophages and T cells in adipose tissue .............................. 8

A role for $B$ cells in obesity........................................... 11

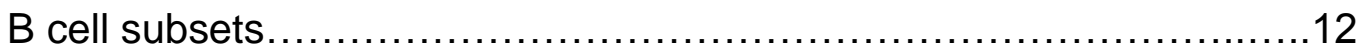

$B$ cell regulation of adipose tissue inflammation and obesity-induced metabolic dysfunction.............................................16

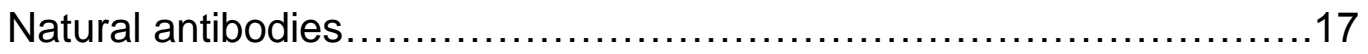

Natural IgM and inflammation......................................... 18

Omental adipose tissue ...................................................

Omental milky spots....................................................

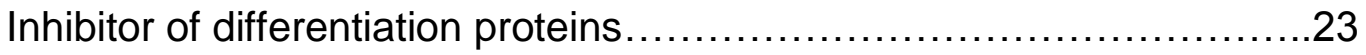

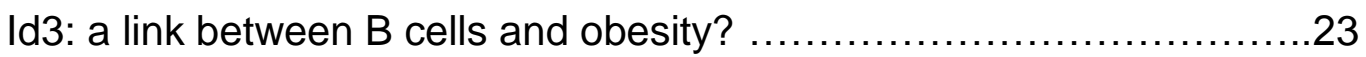

B cell specific Id3 knockout mouse.....................................25

Chapter 2: Materials and Methods...............................................28

Chapter 3: Loss of Id3 in B-1b B Cells Attenuates High-Fat Diet-Induced

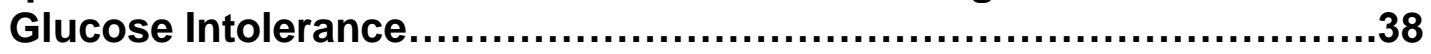

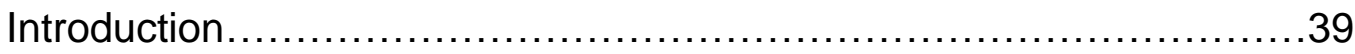

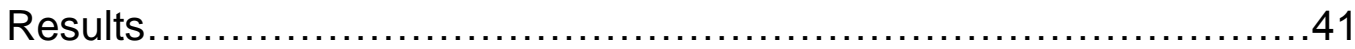


Discussion.

Chapter 4: Adipose Tissue B Cells and IgM Antibodies in an Obese

Human Cohort..............................................................

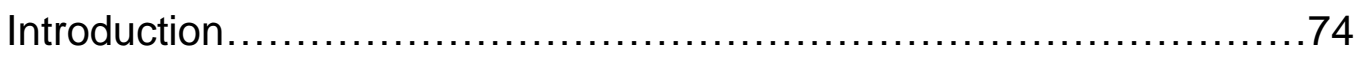

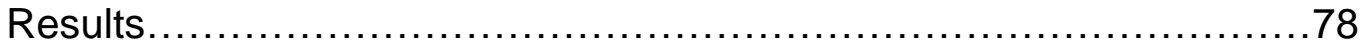

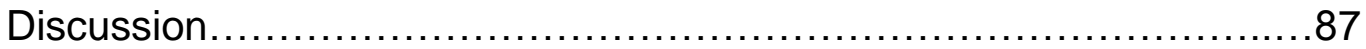

Chapter 5: Summary, General Discussion, and Future Directions............89

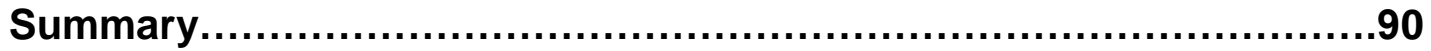

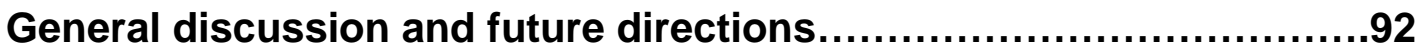

B cells likely regulate obesity and metabolism in a subset-dependent manner.................................................................

B-1b B cells are poorly understood....................................98

B-1b B cells may be an important mediator of adipose tissue and metabolic function.................................................

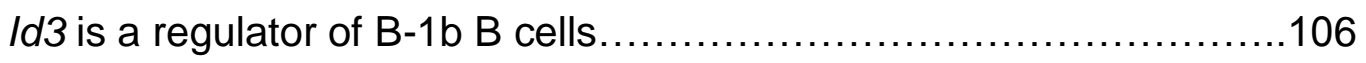

Possible mechanisms for IgM regulation of adipose tissue biology......109

Additional characterization of human $\mathrm{CD} 2 \mathrm{O}^{+} \mathrm{CD} 27^{+} \mathrm{CD} 43^{+} \mathrm{B}$ cells is

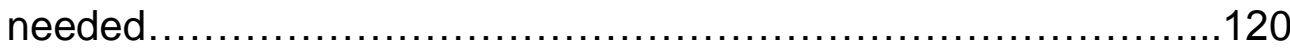

Chapter 6: References...........................................................123 


\section{LIST OF FIGURES}

\section{CHAPTER 1:}

Figure 1. Adipose tissue dysfunction during obesity.....................

Figure 2. Obesity causes adipose tissue inflammation....................9

Figure 3. B cell subsets and known roles in obesity...................13

Figure 4. Multifunctionality of natural IgM antibodies is best summarized by $\mathrm{T} 15$.

Figure 5. Mouse containing a B cell-specific ld3 deletion .26

\section{CHAPTER 2:}

None

\section{CHAPTER 3:}

Figure 6. Loss of $I d 3$ in B cells attenuates HFD-induced glucose intolerance.

Figure 7. Id3 is not required for B-2 B cell driven glucose intolerance in DIO $\mu \mathrm{MT}$ mice.

Figure 8. Adipose tissue-specific increases of B-1 B cells in Id $3^{B}$ cell KO mice fed a HFD

Figure 9. Adipose tissue-specific increases in total IgM and T15 natural IgM antibodies in Id $3^{B}$ cell $\mathrm{KO}$ mice fed a HFD

Figure 10. Peritoneal B-1b B cells are elevated in chow-fed Id $3{ }^{B c e l l K O}$ mice.

Figure 11. No difference in $\mathrm{Id}^{+/+}{ }^{+} \mathrm{CD} 19^{\mathrm{Cre} /+}$ peritoneal $\mathrm{B}-1 \mathrm{a}$ or $\mathrm{B}-1 \mathrm{~b} \mathrm{~B}$ cells.

Figure 12. Loss of $I d 3$ in B cells leads to increased adipose tissue B-1b $B$ cells and IgM secretion in chow-fed mice. .58

Figure 13. Id 3 regulates survival in mature B-1b B cells 61 
Figure 14. Loss of $I d 3$ in B cells leads to reduced inflammation and improved insulin sensitivity in omental fat of mice fed a short-term HFD

Figure 15. B-1b B cells lacking ld 3 attenuate diet-induced glucose intolerance while $B-1 b$ B cells unable to secrete IgM have no effect

\section{CHAPTER 4:}

Figure 16. $C D 20^{+} \mathrm{CD} 27^{+} \mathrm{CD} 43^{+} \mathrm{B}$ cells in human omental adipose tissue correlate with serum PC-IgM levels...................................79

Figure 17. Human omental adipose tissue PC-IgM correlates with serum PC-IgM levels.

\section{CHAPTER 5:}

Figure 18. HFD may lead to splenic germinal center formation..........94

Figure 19. Model for how B-1b B cells may play a protective role in mediating obesity-induced metabolic dysfunction...................102

Figure 20. Possible functions for IgM antibodies in adipose tissue.....111

Figure 21. IgM antibodies may attenuate omental adipose tissue M1 macrophage TNF $\alpha$ secretion........................................118

\section{CHAPTER 6:}

None 


\section{LIST OF TABLES}

\section{CHAPTER 1:}

None

\section{CHAPTER 2:}

None

\section{CHAPTER 3:}

Table 1. IgG antibodies levels in serum and epididymal fat of mice fed a

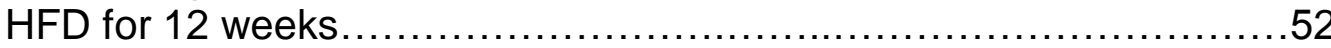

\section{CHAPTER 4:}

Table 2. Cohort 2 baseline characteristics ............................82

Table 3. PC-IgM negatively correlates with serum MCP-1 and age....86

Table 4. IgM autoantibodies and apoB-immune complexes correlate with HDL levels and improved LP-IR scores.........................86

\section{CHAPTER 5:}

None

\section{CHAPTER 6:}

None 


\section{LIST OF ABBREVIATIONS}

BAFF-R

BCR

bHLH

BREGS

CLS

CRP

$\mathrm{DIO}$

dsDNA

FACS

FALC

$\mathrm{Fc} \mu \mathrm{R}$

FFA

FO B cells

FO B cells

GTT

HDL

HFD

$\mathrm{HLH}$

HOMA-IR

HSC

i.p.

Id

Id $3^{-1-}$ mouse

Id $3^{\mathrm{B}}$ cell KO

$\lg \mathrm{M}-\mathrm{IC}$

IL-10

IL-13

IL-1 $\beta$

IL-4

IL-6

INFY
B cell activating factor receptor

$B$ cell receptor

Basic helix-loop-helix

$B$ regulatory cells (undefined family)

Crown-like structures

C-reactive protein

Diet-induced obesity

Double-stranded DNA

Fluorescence-activated cell sorting

Fat-associated lymphoid clusters

IgM Fc receptor

Free fatty acids

Follicular B cells (B-2 family)

Follicular B-2 B cells

Glucose tolerance test

High-density lipoprotein

High-fat diet

Helix-loop-helix

Homeostatic model assessment of insulin resistance

Hematopoietic stem cell

Intraperitoneal

Inhibitor of differentiation

Mouse globally null for Id3

B cell-specific Id3 knockout mouse

IgM immune complexes to apoB

Interleukin-10

Interleukin-13

Interleukin-1 beta

Interleukin-4

Interleukin-6

Interferon gamma 
IRS-1

ITT

LDL

LP-IR

LPS

MBL

MCP-1

MDA-LDL

$\mathrm{MHC}$

MIP-2

MS

MZ B cells

NMR

PAI-1

$\mathrm{PC}$

SC

slgM $^{-/-}$mouse

SLE

STAT3

SVF

T15-IgM; PC-IgM

T2D

TCR

TGF $\beta$

$\mathrm{T}_{\mathrm{H} 1}$

$\mathrm{T}_{\mathrm{H} 17}$

$\mathrm{TH} 2$

TLR

TNFa

TOSO

Tregs

VAT
Insulin receptor substrate-1

Insulin tolerance test

Low-density lipoprotein

Lipoprotein insulin resistance

Lipopolysaccharide

Mannose binding lectin

Monocyte chemoattractant protein-1

Malondialdehyde-low density lipoprotein

Major histocompatibility complex

Macrophage inflammatory protein-2

Milky spots

Marginal zone $B$ cells (B-2 family)

Nuclear magnetic resonance

plasminogen activator inhibitor-1

Phosphocholine

Subcutaneous

Mouse incapable of secreting $\operatorname{lgM}$; does express surface $\lg M$ and secretes $\lg A, \lg E$, and $\lg G$

Systemic Lupus Erythematosus

Signal transducer and activator of transcription-3

Stroma-vascular fraction

$\operatorname{lgM}$ antibodies that recognize PC

Type 2 diabetes

$T$ cell receptor

Transforming growth factor beta

Type 1 helper T cells

IL-17-producing helper T cells

Type 2 helper $T$ cells

Toll-like recptor

Tumor necrosis factor alpha

Fas apoptotic inhibitory molecule

$T$ regulatory cells

Visceral adipose tissue 
xiii

VAT

VLDL

$\mu \mathrm{MT}$ mouse
Visceral adipose tissue

Very low-density lipoprotein

Mouse that lacks mature B cells 
CHAPTER 1:

Introduction 


\section{Pathogenesis of obesity}

Obesity, defined by an excess of body fat, is an epidemic in the Western world, and dramatically increasing rates in developing countries have made it one of the prominent global health concerns of the $21^{\text {st }}$ century. According to the World Health Organization, obesity rates have nearly doubled since 1980. Worldwide, $35 \%$ of adults are overweight, with $11 \%$ being obese. Obesity is a systemic disease that contributes to a wide range of metabolic, cardiovascular, and neurological disorders ${ }^{1-3}$. However, many of these pathophysiological effects stem from obesity-induced insulin resistance and glucose intolerance, two main factors that lead to the development of diabetes ${ }^{4}$. Thus, understanding how obesity impacts glucose metabolism is a key area of study with the ultimate goal of developing preventative treatments for many downstream consequences brought on by obesity.

\section{Adipose tissue dysfunction during obesity}

While obesity induces wide-ranging detrimental effects throughout the entire body, its impact on adipose tissue signaling and function is especially pronounced (Figure 1). Adipose tissue is a highly complex and essential metabolic organ made up of fat cells (adipocytes), connective tissue, vascular cells, and immune cells. In addition to being the predominant site for energy storage, adipose tissue secretes a wide variety of cytokines and hormones that regulate diverse processes including, but not limited to, satiety, blood pressure, 
A

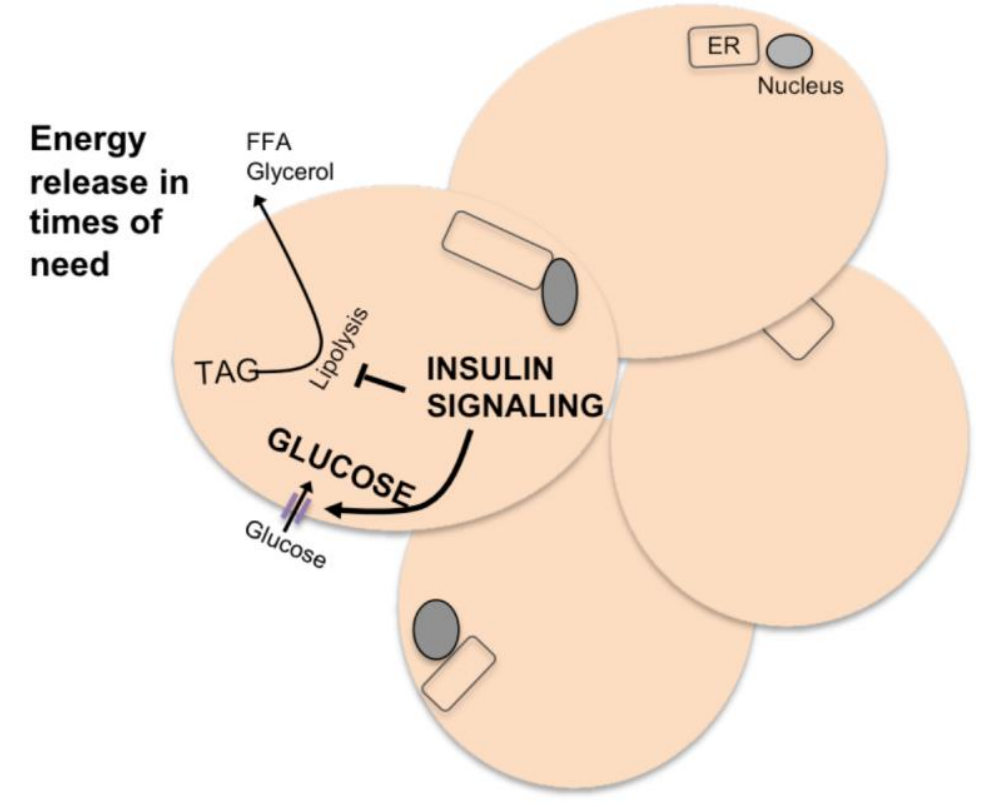

B

Systemic insulin

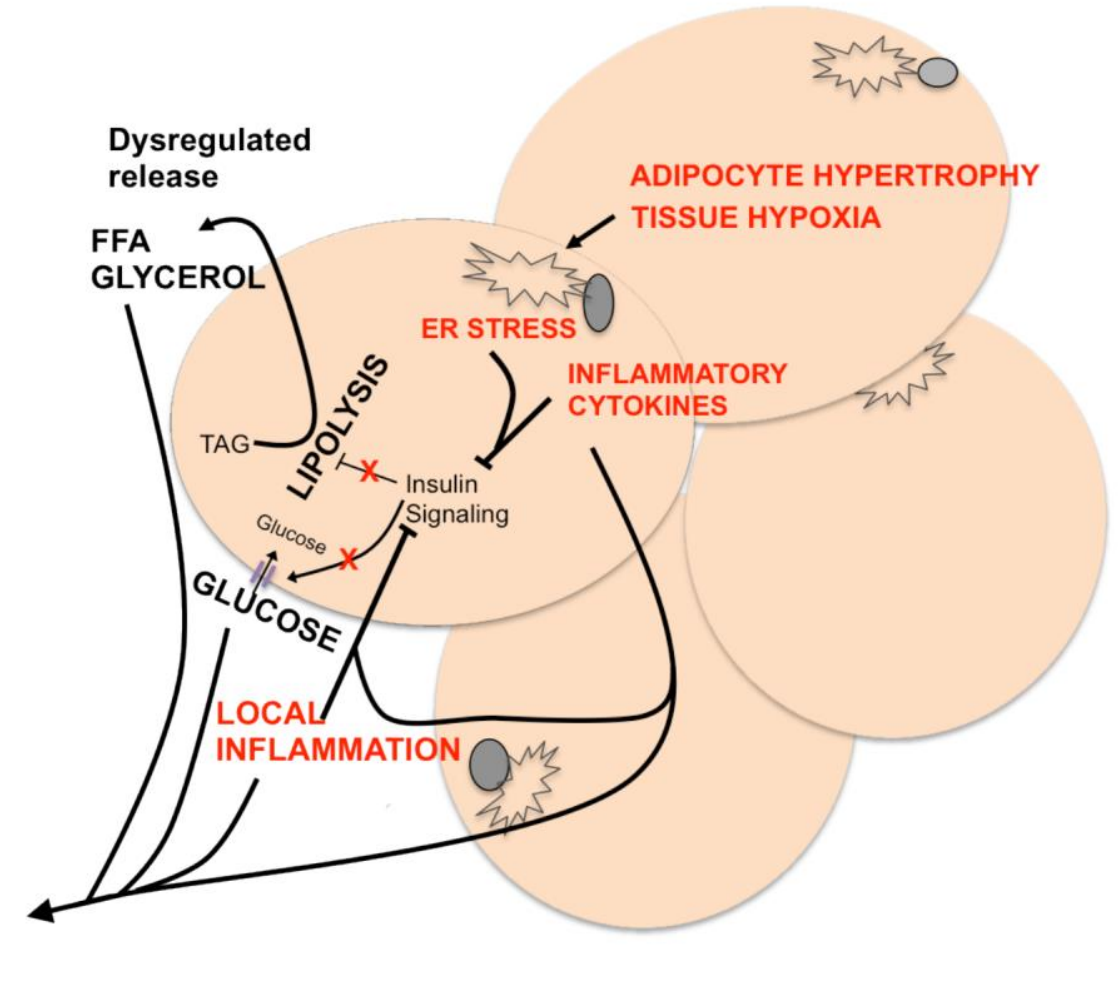
resistance and othe complications 
Figure 1. Adipose tissue dysfunction during obesity. (A) Under normal conditions, glucose uptake and energy release are tightly regulated by insulin signaling. This promotes energy storage when nutrients are in excess and energy release during times of need. (B) In obese adipose tissue, ER stress caused by adipocyte hypertrophy and hypoxia, along with inflammatory cytokines, contribute to impair adipocyte response to insulin. Insulin resistant adipocytes display reduced glucose uptake and increased lipolysis. The uncontrolled release of metabolites and inflammatory factors by adipose tissue can lead to systemic lipo- and gluco-toxicity, insulin resistance, glucose intolerance, and other complications associated with obesity. 
inflammation, and pancreatic insulin secretion ${ }^{5,6}$. During the development of obesity, adipocyte hypertrophy leads to cellular ER stress and causes tissue growth. Expanding adipose tissue that outpaces the available oxygen supply creates a local hypoxic environment, which can further impair cellular function and cause cell death. In parallel, adipocytes, along with immune cells within adipose tissue, increase production of pro-inflammatory factors that serve to directly impact local signaling as well as recruit additional inflammatory cells as part of a feed-forward process. All of these factors contribute to impair adipocyte function and insulin signaling ${ }^{7-15}$, which reduces adipocyte glucose uptake and promotes lipolysis. The resulting breakdown of stored triacylglyceride and release of free fatty acids (FFA) and glycerol contributes to systemic gluco- and lipo-toxicity that impairs metabolic function in other tissues. Utilization of tissuespecific knockout mice has provided evidence that enhancing insulin sensitivity in adipocytes improves hepatic and skeletal muscle insulin sensitivity ${ }^{16-18}$, whereas impairing adipocyte insulin signaling leads to insulin resistance in these insulinsensitive tissues ${ }^{19}, 20$. Interestingly, altering insulin sensitivity in either liver or muscle tends to only impact local signaling ${ }^{21-24}$. These findings indicate that obesity-induced adipose tissue insulin resistance has widespread systemic metabolic effects.

\section{Adipose tissue distribution}

Nearly 70 years ago, it was first observed that adult humans display two distinct patterns of fat distribution ${ }^{25}$. Subsequent studies demonstrated that 
accumulation of upper-body fat, rather than lower-body fat, was associated with various chronic diseases ${ }^{26}$. Since then, many studies comparing anatomical fat distribution (reviewed elsewhere ${ }^{27-29}$ ) confirmed that intra-abdominal visceral adipose tissue (VAT) accumulation is more closely associated with impaired insulin sensitivity and type 2 diabetes development than increased subcutaneous (SC) fat ${ }^{30-33}$. Adipocytes from VAT are more metabolically active, and VAT is a greater source of obesity-induced pro-inflammatory cytokines than SC fat ${ }^{8,10}$. In addition, surgical removal of $\mathrm{VAT}^{34,35}$, but not $\mathrm{SC}$ fat ${ }^{36,37}$, results in improved insulin sensitivity. In light of these findings, it is well accepted that obesityinduced changes in VAT signaling and function contribute strongly to downstream metabolic disease.

\section{Inflammation and insulin resistance}

Anti-inflammatory drugs have long been known to lower blood sugar levels in diabetic patients ${ }^{38,39}$, and studies in the 1980 s noted systemic insulin resistance in pathological inflammatory states such as sepsis ${ }^{40,41}$, endotoxemia ${ }^{42}$, and trauma ${ }^{43}$. However, it was not until 1991 that treatment of adipocytes with the inflammatory factor tumor necrosis factor alpha (TNFa) was shown to impair insulin-stimulated glucose uptake ${ }^{44}$. Several years later, this effect was rescued in obese rats by TNFa neutralization ${ }^{45}$. Additional mechanistic studies indicated that TNFa promotes insulin resistance through insulin receptor substrate-1 (IRS-1) serine phosphorylation, which inhibits insulin-induced IRS-1 tyrosine phosphorylation and prevents downstream insulin signaling ${ }^{46-49}$. The in 
vivo relevance of these studies was confirmed when two groups independently generated TNFa knockout mice that were protected against high-fat diet (HFD)induced glucose intolerance and insulin resistance ${ }^{50,51}$. These findings sparked clinical studies that demonstrated circulating levels of TNFa, as well as other inflammatory factors such as interleukin-6 (IL-6) and C-reactive protein (CRP), were not only positively associated with human obesity, insulin resistance, and diabetes ${ }^{52-56}$, but were also predictive of future type 2 diabetes (T2D) diagnosis in healthy patients ${ }^{57,58}$.

While analyzing circulating factors helped identify a novel link between inflammation and obesity-induced metabolic dysfunction, it was still unclear where this immune response was located or which cells were involved. In the same study that identified the insulin sensitizing effects of TNFa neutralization, Spiegelman and colleagues demonstrated that TNFa expression was elevated in adipose tissue of obese rodents ${ }^{45}$. Additional studies showed that TNFa expression in human adipose tissue correlated strongly with obesity and insulin resistance, and local expression decreased following weight loss and improved insulin sensitivity ${ }^{59-61}$. Further analysis of human and murine adipose tissue revealed enriched expression of various inflammatory markers including plasminogen activator inhibitor-1 (PAI-1), IL-6, and transforming growth factor beta $(\operatorname{TGF} \beta)^{62-65}$, together suggesting that adipose tissue may harbor previously unknown immune activity. Indeed, studies shortly thereafter in mice ${ }^{66}$ and humans ${ }^{67}$ identified macrophages in adipose tissue. Finally, in 2003, two seminal publications ${ }^{68,69}$ demonstrated that bone marrow-derived macrophages 
accumulate in obese adipose tissue and produce several of the previously identified pro-inflammatory factors, thus contributing substantially to the local inflammatory environment. These findings strengthened the hypothesis that obesity is a disease of chronic inflammation, and that adipose tissue may be the epicenter of a detrimental immune response.

\section{Macrophages and T cells in adipose tissue}

Since these initial reports, much work has gone into characterizing the immune cell phenotype within adipose tissue, and how cell composition changes during obesity (Figure 2). Elegant studies utilizing genetic knockouts of inflammatory factors and transfer or ablation of specific immune cell subsets have helped identify key roles for macrophages and T cells in regulating adipose tissue function. Here, a brief summary of these findings is provided, as they have been reviewed extensively elsewhere ${ }^{70-75}$. In lean adipose tissue, alternatively activated M2 macrophages are found in abundance and secrete the antiinflammatory cytokine interleukin-10 (IL-10) that blunts inflammatory cell activity and directly promotes adipocyte insulin sensitivity. IL-10 is also secreted by regulatory $T$ cells (TREGS), and type 2 helper $\left(T_{H} 2\right)$ T cells produce interleukin- 4 
A

\section{Lean Adipose Tissue}

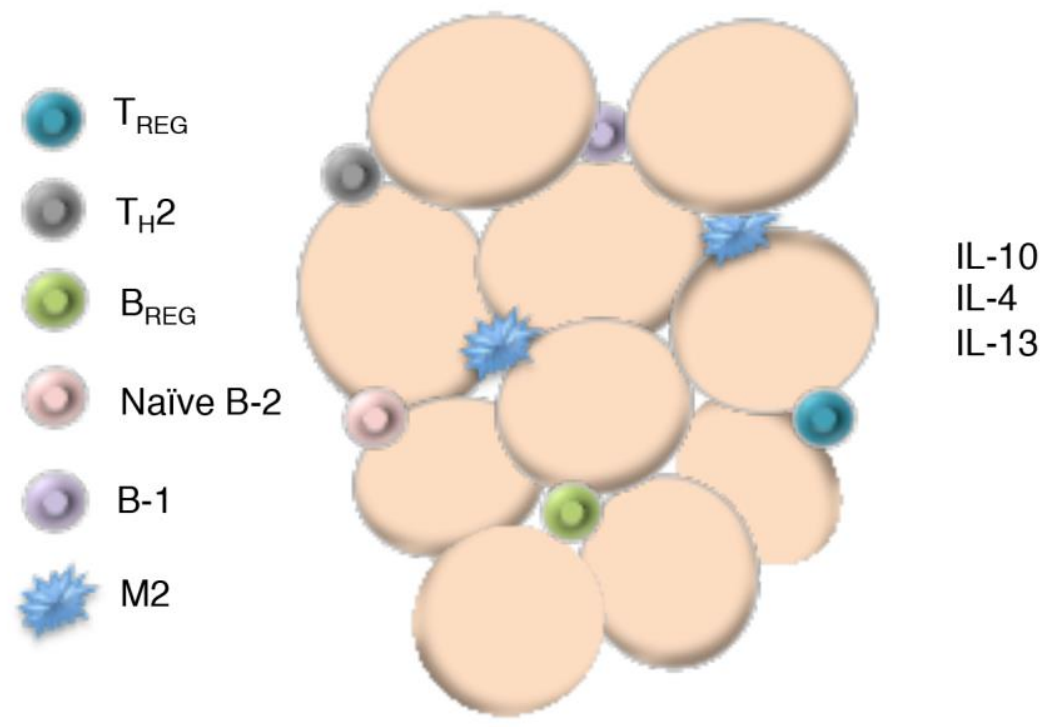

B

Obese Adipose Tissue

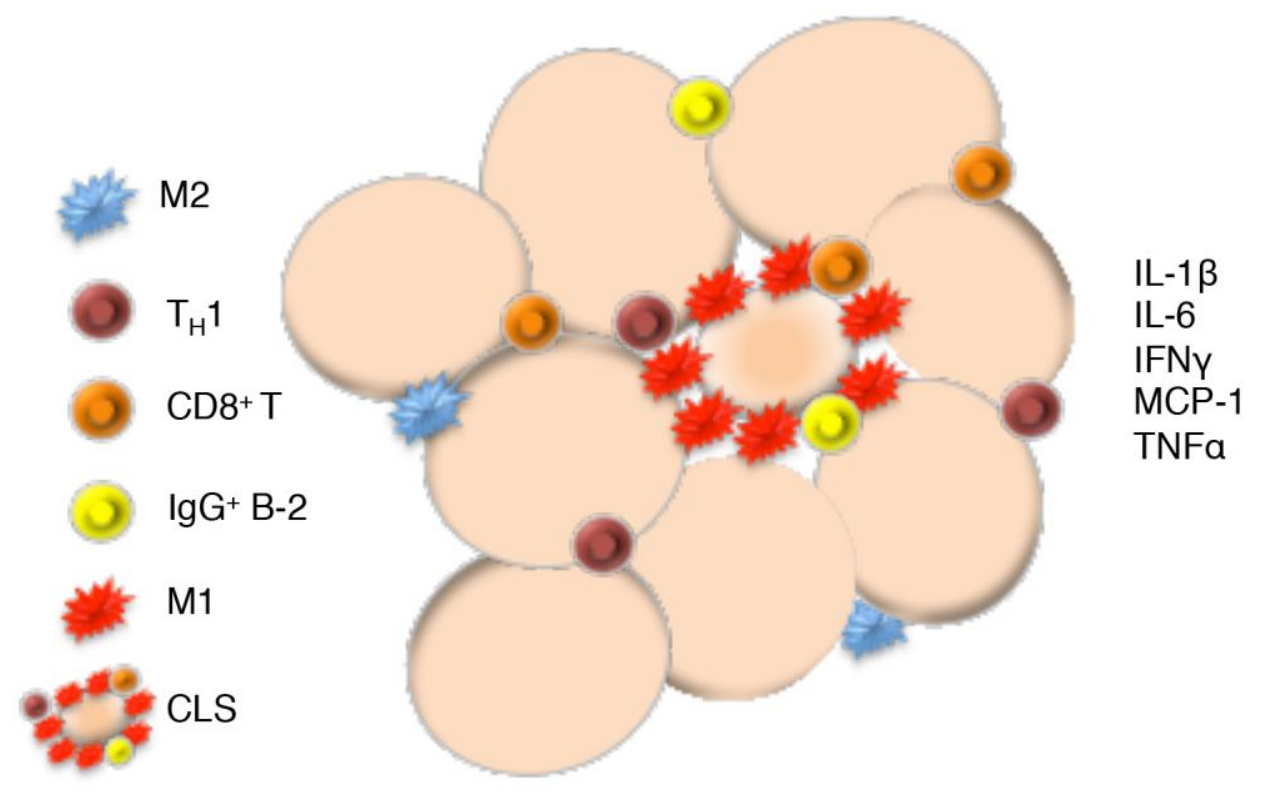


Figure 2. Obesity causes adipose tissue inflammation. (A) Resident immune cells in lean adipose tissue primarily possess regulatory functions and secrete anti-inflammatory cytokines. (B) During obesity, inflammatory immune cells infiltrate adipose tissue. Obese adipose tissue is characterized by elevated proinflammatory cytokines and clusters of M1 macrophages surrounding dead adipocytes called crown-like structures (CLS). 
(IL-4) and interleukin-13 (IL-13) that help maintain M2 macrophage signaling. During the onset of obesity, visceral adipose tissue experiences an influx of inflammatory cells. Obese adipose tissue produces elevated levels of monocyte chemoattractant protein-1 (MCP-1) that serves to recruit circulating monocytes that differentiate into classically activated M1 macrophages once they enter the tissue. M1 macrophages form clusters around dead and dying adipocytes called crown-like structures (CLS) where they secrete high levels of TNFa and interleukin-1 beta (IL-1 $\beta$ ). These factors impair adipocyte function by inhibiting insulin sensitivity and inducing secretion of inflammatory cytokines and lipids that further activate M1 macrophages. This feed-forward loop is further exacerbated by type 1 helper ( $\left.\mathrm{T}_{\mathrm{H}} 1\right)$ and $\mathrm{CD} 8^{+}$cytotoxic $\mathrm{T}$ cells that enter obese adipose tissue and secrete interferon gamma (INFY), a cytokine that also serves to activate M1 macrophages and impair insulin sensitivity in adipocytes. Together, these findings have not only identified a clear pathogenic effect of adipose tissue inflammation, but have illustrated that immune function within adipose tissue is a highly complex process involving many more participants than originally thought.

\section{A role for $B$ cells in obesity}

B cells are unique immune cells that secrete antibodies, which bind specific antigens. While B cells are also found in adipose tissue ${ }^{76-82}$, their role(s) in mediating local inflammation and adipose tissue function have not been fully explored. CD19+ $B$ cells have been reported to infiltrate murine epididymal adipose tissue prior to M1 macrophages during the early stages of diet-induced 
obesity $(\mathrm{DIO})^{78}$, and $\mathrm{B}$ cells were found in sites of inflammation within SC adipose tissue of obese humans ${ }^{80}$. In addition, B cell-deficient ( $\left.\mu \mathrm{MT}\right)$ mice fed a HFD gain less weight, have reduced adipose tissue inflammation, and display improved insulin signaling and glucose tolerance compared to WT controls ${ }^{77,81}$, suggesting that $B$ cells do play a role in regulating the metabolic effects of obesity. While only a few studies have looked in depth at specific roles B cells may play in this context, results highlighted below indicate that, similar to what we know about macrophages and T cells, B cell regulation of adipose tissue inflammation and insulin resistance is likely subset-dependent.

\section{B cell subsets}

B cells are divided into two functionally distinct families, B-1 and B-2 (Figure 3). Follicular (FO) B-2 B cells undergo class switching and somatic hypermutation in response to T-dependent antigen. These cells then either differentiate into long-lived plasma cells that spontaneously secrete high amounts of antibody, or become memory B cells that are primed for a rapid antibody response after antigen re-exposure ${ }^{83}$. Antibodies secreted from terminally differentiated FO B-2 cells are highly antigen specific and comprise an essential component of the adaptive immune system ${ }^{84,85}$. Marginal zone (MZ) B cells are another class of B-2 B cells that reside in the splenic marginal zone ${ }^{86} . M Z B$ cells 


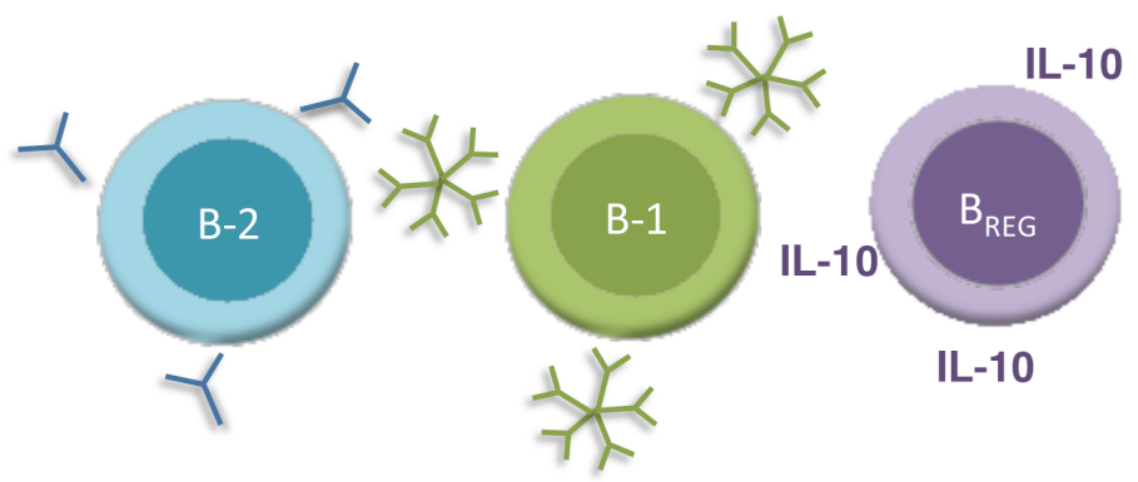

\begin{tabular}{|c|c|c|c|}
\hline Major function & $\begin{array}{l}\text { T-dependent, long- } \\
\text { lived humoral } \\
\text { immunity }\end{array}$ & $\begin{array}{l}\text { T-independent, } \\
\text { early defense, } \\
\text { tissue } \\
\text { homeostasis }\end{array}$ & $\begin{array}{l}\text { Inflammation } \\
\text { resolution }\end{array}$ \\
\hline $\begin{array}{l}\text { Major secreted } \\
\text { product }\end{array}$ & $\begin{array}{l}\text { High affinity, class- } \\
\text { switched antibodies }\end{array}$ & $\begin{array}{l}\text { Low affinity, IgM } \\
\text { natural antibodies }\end{array}$ & IL-10 \\
\hline Role in obesity & $\begin{array}{l}\text {-Increased } \\
\text { inflammatory } \\
\text { cytokine production } \\
\text { in obesity } \\
\text { - IgG antibodies } \\
\text { promote adipose } \\
\text { tissue inflammation, } \\
\text { insulin resistance, } \\
\text { and glucose } \\
\text { intolerance }\end{array}$ & $\begin{array}{l}\text {-Present in } \\
\text { adipose tissue, } \\
\text { but function } \\
\text { unknown }\end{array}$ & $\begin{array}{l}\text {-Decreased IL-10 } \\
\text { production in } \\
\text { obesity } \\
\text {-B cell-derived } \\
\text { IL-10 attenuates } \\
\text { inflammation and } \\
\text { insulin resistance }\end{array}$ \\
\hline
\end{tabular}


Figure 3. B cell subsets and known roles in obesity. B cells can be divided into two major subsets: B-1 and B-2. It is unclear whether IL-10-secreting BREG B cells belong to either subset or develop independently. B cell subsets differ in their function within the immune system, and our limited understanding suggests their roles in obesity may vary as well. However, much more study is needed to understand how $B$ cells function in adipose tissue and how they may impact obesity-associated metabolic disease. 
are components of the innate immune system that respond immediately to circulating antigens filtered through the spleen.

B-1 B cells develop from a distinct lineage earlier in ontogeny than B-2 B cells and reside primarily in the coelomic cavities and spleen ${ }^{87-89}$. Although most characterization of B-1 B cells stems from murine studies, recently a human B cell subset with B-1-like characteristics was identified ${ }^{90}$. Despite being fewer in number than B-2 B cells, B-1 B cells possess the unique ability among B cells to self-renew ${ }^{91}$, allowing for a smaller number of cells to maintain a functional population. B-1 B cells are further divided into B-1a and B-1b B cells that have overlapping functions, but exhibit differences in activation and response to infection $^{92-95}$. Both B-1 subsets secrete antibodies that are termed "natural antibodies" because they are produced without previous antigen exposure. As antibodies from B-1 B cells are produced spontaneously or in immediate response to stimulation, are independent of $\mathrm{T}$ cell help, and do not require affinity maturation, B-1 humoral responses are quicker than those from B-2 B cells and play key preventative roles during the early stages of infection ${ }^{96}$.

Regulatory B cells (BREGS) are a recently discovered group of B cells that suppress inflammation primarily through IL-10 production $^{97,98}$. As B cells expressing a mix of surface markers generally used to define B-1 and B-2 B cell subsets have been shown to secrete IL-10, it is currently unclear whether these B cells represent unique developmental subsets or if $\mathrm{IL}-10$ production is a shared feature among various B cell families. Given their potential therapeutic use in 
treating autoimmune and inflammatory disease, additional studies of these unique B cells are needed.

\section{B cell regulation of adipose tissue inflammation and obesity-induced metabolic dysfunction}

Several studies have demonstrated specific roles for B cells in obesityinduced inflammation and downstream metabolic dysfunction (Figure 3). Mice null for $\mathrm{B}$ cell activating factor receptor (BAFF-R) have a severely reduced B-2 B cell population ${ }^{99}$ and, when challenged with a HFD, display attenuated adipose tissue inflammation as well as improved insulin sensitivity and glucose tolerance compared to WT controls ${ }^{100}$. Another study found FO B cells from obese mice to secrete increased IL-6 and reduced IL-10 compared to cells from lean controls, suggesting an inflammatory phenotype ${ }^{77}$. Interestingly, mice fed a HFD displayed an influx of class-switched B-2 B cells, as well as IgG antibodies, within visceral adipose tissue ${ }^{81}$. Adoptive transfer of WT B-2 B cells, but not B-2 B cells with impaired ability to present antigen, were able to drive insulin resistance in $\mu \mathrm{MT}$ mice. This group went on to show that IgG, but not IgM, from DIO mice activated macrophage TNFa production and was sufficient to induce systemic insulin resistance and glucose intolerance. Together, these findings suggest that B-2 B cells promote diet-induced insulin resistance through an adaptive IgG humoral response.

Very little is known about potential roles of other B cell subsets in obesity and diet-induced metabolic dysfunction. B cells from type 2 diabetic patients 
display impaired IL-10 secretion compared to $B$ cells in non-diabetics ${ }^{101}$. A recent study identified IL-10-producing B cells within adipose tissue and showed that B cell-specific deletion of IL-10 attenuated the inflammatory effects of obesity and protected against HFD-induced insulin resistance and glucose intolerance ${ }^{102}$. These findings suggest that different B cell families may have contrasting functions in the context of obesity-induced metabolic disease. Although B-1 B cells are enriched in adipose tissue compared to other compartments ${ }^{81}$ and comprise a large fraction of milky spots found in omental fat ${ }^{82}$, their role in obesity is unknown.

\section{Natural antibodies}

Natural antibodies ${ }^{103}$, primarily produced by B-1 B cells in mice, are generally of the IgM isotype and arise independent of antigen exposure in mice and humans. Unlike antibodies derived from B-2 B cells, natural antibodies do not undergo affinity maturation and contain few point mutations or non-templated nucleotide additions ${ }^{104}$. Interestingly, natural antibody repertoires of naïve individuals demonstrate similarity both within ${ }^{105-108}$ and across ${ }^{109,} 110$ species, providing evidence that these antibodies are not generated randomly. Indeed, natural antibody repertoires demonstrate preferential heavy and light chain pairings that allow for recognition of conserved structures such as carbohydrates, nucleic acids, and phospholipids that are often found on the surface of foreign pathogens ${ }^{111-114}$. In some cases, these same epitopes are expressed on damaged self-cells ${ }^{109}$; thus providing natural antibodies dual roles in preventing 
infection and maintaining tissue homeostasis. The best-studied example of this multi-functionality is the T15 family of natural antibodies that recognize a phosphocholine $(\mathrm{PC})^{115}$ moiety expressed on pneumococcal cell membranes as well as on the surface of apoptotic cells ${ }^{116}$ (Figure 4). IgM specific for PC (T15IgM or PC-IgM) plays important roles in protecting against lethal Streptococcus pneumoniae infection ${ }^{117,} 118$ and facilitating apoptotic cell clearance ${ }^{116,119,120 .}$ These studies have helped demonstrate a unique regulatory niche for natural antibodies in a layered immune system.

\section{Natural IgM and inflammation}

Multiple factors inherent to natural antibodies contribute to their general anti-inflammatory function ${ }^{121,122}$. First, IgM is less inflammatory than IgG. The $\mu$ constant region of IgM antibodies cannot bind activating Fc $\gamma$ receptors responsible for triggering inflammatory responses induced by certain IgG isotypes (i.e., IgG2a/c and IgG2b in mice). Second, natural IgM antibodies promote efficient apoptotic cell clearance that prevents the accumulation of dead cells $^{116,119,120,123-125}$. The cellular contents from uncleared dead cells promote inflammation and can introduce the body to normally hidden auto-antigens ${ }^{126,127}$. Indeed, mice lacking the ability to secrete IgM have defective apoptotic cell 


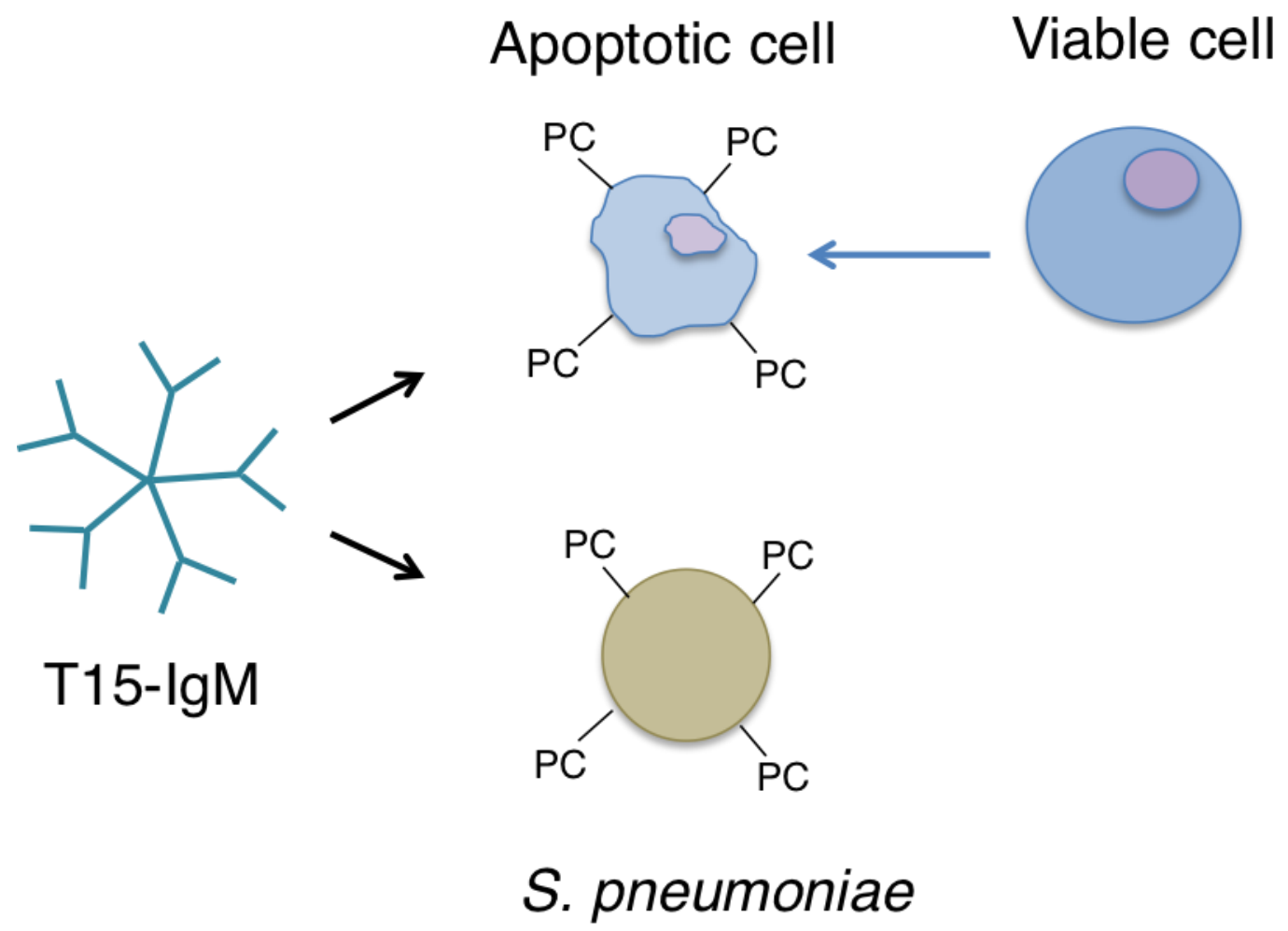


Figure 4. Multifunctionality of natural IgM antibodies is best summarized by T15. Natural antibodies arise without previous antigen exposure and often recognize evolutionarily conserved moieties. The T15 family of natural antibodies recognizes a phosphocholine (PC) epitope that is expressed on certain gram positive bacteria such as $S$. pneumoniae, as well as on apoptotic cells. PCrecognizing IgM can promote bacteria neutralization and facilitate apoptotic cell clearance, thus playing important roles in initial defense against invading pathogens and in maintaining tissue homeostasis. (Adapted from Binder, Nat. Med., 2002 ${ }^{128}$ ) 
clearance $^{123}$ and develop a Systemic Lupus Erythematosus (SLE)-like phenotype characterized by inflammatory IgG auto-antibodies directed at double-stranded DNA (dsDNA) ${ }^{129}$. In addition, IgM antibodies have been shown to reduce apoptotic cell numbers and macrophage content of atherosclerotic plaques ${ }^{130}$, suggesting a protective role in a model of diet-induced inflammation. Third, recent evidence suggests IgM natural antibodies can directly attenuate inflammation in myeloid cells. While the mechanism has yet to be elucidated, T15-IgM treatment significantly attenuated lipopolysaccharide (LPS)-stimulated TNF $\alpha$ and IL- 6 production by RAW264.7 macrophages and impaired primary dendritic cell activation ${ }^{119}$. Together, B-1 B cell-derived natural IgM antibodies can function through various pathways to attenuate inflammation. However, while $\lg \mathrm{M}$ antibodies have been reported in adipose tissue ${ }^{81}$, their ability to regulate diet-induced adipose tissue inflammation or downstream insulin resistance has not been evaluated.

\section{Omental adipose tissue}

The omentum is a unique fatty tissue attached to the greater curvature of the stomach that comprises the largest visceral adipose tissue depot in humans. The omentum has long been known for its role in preventing infection and promoting wound healing and tissue regeneration within the peritoneal cavity (reviewed elsewhere ${ }^{131-133}$ ). While recent studies in humans have shown omental adipose tissue inflammation associates with insulin resistance ${ }^{134,135}$, most rodent studies on adipose tissue function in obesity focus on perigonadal depots 
(epididymal in males, parametrial in females) that are not present in primates or humans. Although these fat deposits make up the largest adipose regions in mice, their systemic drainage allows for secreted metabolites and cytokines to bypass the liver, thus diluting their metabolic impact. In contrast, inflammatory factors produced by portally-draining omental adipose tissue go directly into the liver where they can impact systemic metabolism ${ }^{136,137}$. Indeed, epididymal adipose tissue transplants led to substantial systemic insulin resistance in recipients when connected portally compared to systemically ${ }^{138}$. While mice do have omental adipose tissue that displays similar structural characteristics as in humans ${ }^{139}$, surprisingly few studies have evaluated murine omental fat in the context of obesity.

\section{Omental milky spots}

In addition to differences in drainage, the immune cell composition and organization distinguishes murine and human omental adipose tissue from other depots. In SC and epididymal fat, immune cells are primarily found interspersed between adipocytes. However, omental adipose tissue contains organized clusters of macrophages and B cells that reside adjacent to adipose-rich areas. These cell clusters are called milky spots due to their opaque white appearance, and have been described since the mid-nineteenth century ${ }^{140}$. Milky spots (MS) trap intraperitoneal (i.p.)-injected antigens, expand during peritoneal infection, and contribute moderate immunity in mice lacking traditional lymphoid tissues such as lymph nodes and Peyer's patches ${ }^{82,133,141,142 .}$. While thorough immuno- 
phenotyping of MS is lacking in humans, the majority of B cells residing in murine MS are B-1 B cells ${ }^{82}$. This is in contrast to the recently discovered fat-associated lymphoid clusters (FALCs) that populate human and murine mesenteric fat and contain large numbers of "natural helper" lymphocytes, but few B cells ${ }^{143}$. Thus, further study of omental fat may enhance our understanding of how B cells function within adipose tissue, and particularly, how their activity may mediate the metabolic dysfunction caused by obesity.

\section{Inhibitor of differentiation proteins}

Inhibitor of differentiation (Id) proteins are helix-loop-helix (HLH) factors that regulate transcription in a dominant-negative manner ${ }^{144-146}$. While Id proteins are known to regulate cell cycle progression, differentiation, and survival, their exact function can vary widely between cell types ${ }^{147}$. Four known ld homologs named sequentially in order of discovery Id1-Id4 - exist in humans and rodents. In general, Id expression is highest in developing tissues and proliferating cells, while decreasing in healthy adult tissues and terminally differentiated or quiescent cells ${ }^{147,}{ }^{148}$. Genetic knockout studies have demonstrated that while no single Id gene is essential for viability, various combinations of double Id knockouts confer embryonic lethality ${ }^{149}$, suggesting that Id proteins have overlapping but non-redundant functions.

\section{Id3: a link between B cells and obesity?}


Id3 has been implicated in B cell development, activation, and antibody response. While $I d 3$ is similar to other Ids in that it is highly expressed in the embryo and progressively declines during development ${ }^{150-152}$, Id3 is present in both developing and mature lymphocytes ${ }^{153,154}$. In developing lymphocytes and B cell progenitors, Id3 expression prevents maturation by inducing apoptosis ${ }^{155 \text {, }}$ ${ }^{156}$ and downregulation of $I d 3$ is essential for $\mathrm{B}$ cell lineage commitment ${ }^{157}$. In contrast, Id 3 is quickly upregulated following antigen stimulation by $\mathrm{B}$ cell receptor $(\mathrm{BCR})$ crosslinking and promotes $\mathrm{BCR}$-mediated proliferation in $\mathrm{B}-2 \mathrm{~B}$ cells $^{158}$. Furthermore, Id3 has been shown to regulate immunoglobulin classswitching in activated B-2 B cells ${ }^{158-160}$, suggesting that $I d 3$ may be involved in various aspects of antibody response.

Studies using mice globally null for $I d 3\left(I d 3^{--}\right)$suggest that $I d 3$ may be a key regulator of both $\mathrm{B}$ cell function and obesity development. While $/ d 3^{-/-}$mice have relatively normal numbers of splenic B-2 B cells ${ }^{158,161}$, they have impaired antigen-specific antibody responses ${ }^{158}$. In contrast, several studies have indicated that $I d 3^{--}$mice have increased titers of IgM antibodies at baseline ${ }^{162,163}$. Recently, we showed that global loss of $I d 3$ results in reduced VAT expansion and attenuated $\mathrm{DIO}^{164}$. In this study, we identified high Id3 expression in the stroma-vascular fraction (SVF) of VAT, suggesting that Id3 may function in a non-adipocyte cell in adipose tissue. Together, these findings suggest that $I d 3$ likely plays important roles both in regulating $B$ cell function and obesity development. 


\section{B cell specific Id3 knockout mouse}

The use of the $I d 3^{-/}$mouse has generated many questions regarding Id 3 's role in B cell biology and obesity progression. However, Id3's ubiquitous expression during development and known regulation of T cell function ${ }^{165-169}$ made it necessary to generate a B cell-specific knockout mouse to address whether Id 3 function in B cells directly impacts DIO. To accomplish this, we crossed floxed $I d 3\left(\operatorname{Id} 3^{f / / f l}\right)$ mice ${ }^{170}$ containing LoxP sites flanking the first two exons of Id3 with CD19cre (CD19 $\left.{ }^{\mathrm{Cre} /+}\right)$ mice containing the Cre recombinase gene knocked into the first coding exon of the pan B cell marker, CD19 (Figure $5 \mathrm{~A})$. The resulting $C 57 \mathrm{~B} / / 6 \mathrm{Id} 3^{\mathrm{fl/fl} C} \mathrm{CD} 1 \mathrm{~g}^{\mathrm{Cre} /+}\left(\mathrm{Id} 3^{\mathrm{B} \text { cell } \mathrm{KO}}\right)$ mouse lacked $/ d 3$ only in $\mathrm{B}$ cells (Figure 5B). As described in chapter 3 , this mouse provided us a unique tool to explore potential ways B cells regulate HFD-induced metabolic dysfunction. 
A
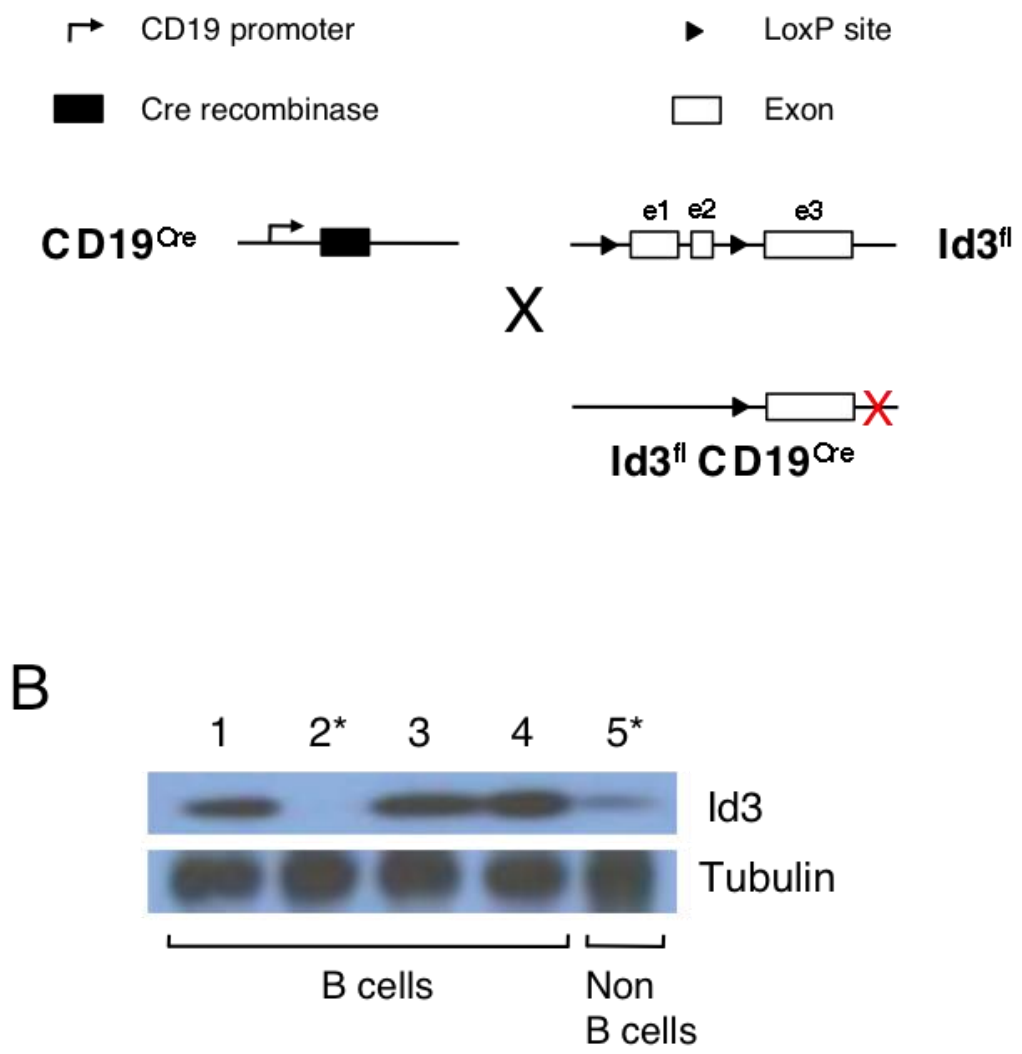
Figure 5. Mouse containing a B cell-specific Id3 deletion. (A) Schematic showing CD19cre x Floxed Id3 cross to generate Id3BcellKO mouse. (B) Id3 Western blot of purified splenic B cells (lanes 1-4) or B cell-depleted splenocytes (lane 5). Numbers represent cells from the following genotypes: $1=\mid \mathrm{d} 3 \mathrm{fl} /+$ CD19cre/+; 2=ld3fl/fl CD19cre/+; 3=ld3fl/fl CD19+/+; 4=Id3+/+ CD19cre/+; $5=\mathrm{Id} 3 \mathrm{fl} / \mathrm{fl} \mathrm{CD} 19 \mathrm{cre} /+.{ }^{*}$ Cells from Id3 ${ }^{\mathrm{Bcell}} \mathrm{KO}$ mice. 


\section{CHAPTER 2:}

Materials and Methods 


\section{Animals:}

All animal protocols were approved by the Animal Care and Use Committee at the University of Virginia. C57BI/6J and $\mu \mathrm{MT}$ mice were purchased from Jackson Laboratory (stock\# 000664 \& 002288, respectively). $I d 3^{-/-}$and $/ d 3^{f / / f l}$ mice were a generous gift of Dr. Yuan Zhang (Duke University), CD19cre/+ and Rag1\%mice were gifted by Timothy Bender (University of Virginia), and $s / g M^{-/}$mice were kindly provided by Dr. Peter Lobo (University of Virginia). Id $3^{f / / f l}$ mice were crossed to $C D 19^{c r e /+}$ mice to generate $I d 3^{f / / f I} C D 19^{c r e /+}$ mice. These mice were then bred to $/ d 3^{f / / f l} C D 19^{+/+}$mice to generate $/ d 3^{f / / f l} C D 19^{c r e /+}\left(\operatorname{ld} 3^{B}\right.$ cell KO$)$ and littermate control $/ d 3^{t / / f l} \mathrm{CD} 19^{+/+}(\mathrm{WT})$ mice. All mice were on a pure $\mathrm{C} 57 \mathrm{BL} / 6$ background, and confirmation of B cell specific Id3 deletion was confirmed by PCR and Western blot ${ }^{171}$. Only male mice were used for experiments, and all animals were given standard chow diet and water ad libitum until they were genotyped. For high-fat feeding studies, littermates were placed on a $60 \% \mathrm{kCal}$ fat diet (Research Diets, D12492) for the designated length of time.

\section{Metabolic analysis}

For all metabolic studies, mice were fasted for the designated time in individual wood chip-lined cages. Mice had access to water ad libitum throughout all experiments.

Glucose tolerance test (GTT): Mice were fasted overnight. At the beginning of each experiment, a small tail snip was made and baseline blood glucose levels were determined. Mice were then injected i.p. with 1.4-2.0g dextrose (Hospira) 
per kg body weight, and blood glucose levels were measured at 10, 20, 30, 60, 90 , and 120 minutes post-injection.

Insulin tolerance test (ITT): Mice were fasted for four hours. Baseline blood glucose levels were determined as in GTT. Mice were injected with $(0.75 \mathrm{U} / \mathrm{kg})$ insulin (Eli Lilly), and blood glucose levels were measured at 15, 30, 60, 90, and 120 minutes post-injection and normalized to baseline readings.

Insulin signaling studies: Following an overnight fast, mice were injected with 10U/kg insulin (Eli Lilly). Mice were euthanized after five minutes and omental adipose tissue was removed and flash-frozen for later analysis (see tissue processing and Western blot protocol below).

\section{Adoptive transfers:}

B-2 adoptive transfer: Donor C57BI/6 and Id3 $3^{-/}$mice, along with host $\mu \mathrm{MT}$ mice were fed a HFD for eight weeks prior to transfer. Splenic B-2 cells (>98\% purity) were harvested from donor animals as described previously ${ }^{162}$. Hosts received a single i.p. injection of either $10^{7} \mathrm{~B}-2 \mathrm{~B}$ cells in $300 \mu$ saline or saline alone (vehicle control), and were continued on a HFD for the remainder of the experiment.

B-1b adoptive transfer: Pooled peritoneal fluid from 8-12 week old WT, Id $3^{B}$ cell Ko, or $s \lg M^{-/}$donor mice was stained with fluorophore-labeled antibodies (see

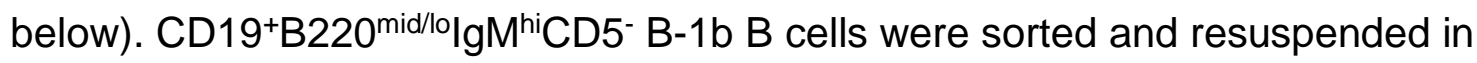
$200 \mu$ saline. Eight-ten week old Rag $1 \%$ hosts were injected with either $8.0 \times 10^{4} \mathrm{~B}$ - 
$1 \mathrm{~b}$ B cells or with saline alone (vehicle control). Hosts were allowed one week to recover before being placed on a HFD for the remainder of the experiment.

\section{Tissue processing}

Murine flow cytometry: Splenocytes, peritoneal cells, and epididymal stromavascular fraction were isolated as previously described ${ }^{164,171}$ Cells from omental adipose tissue were obtained using a "walk-out" method ${ }^{172}$. Human flow cytometry: Omental and subcutaneous adipose tissue was processed using methods adapted from Zimmerlin et al. ${ }^{173}$. In brief, adipose tissue was placed in PBS supplemented with $5.5 \mathrm{mM}$ glucose and $50 \mu \mathrm{g} / \mathrm{ml}$ gentamicin and processed as soon after collection as possible. Ten (g) adipose tissue was minced with scissors and digested in 30ml PBS containing 1\% BSA (Gemini) and 2.5g/L Collagenase II (Worthington) in a shaking $37^{\circ}$ incubator for 15 minutes. PBS containing $0.1 \%$ BSA and $1 \mathrm{mM}$ EDTA was added to stop the collagenase activity. The SVF was then successively passed through $425 \mu \mathrm{m}$ and $180 \mu \mathrm{m}$ sieves (WS Tyler), and finally through a $40 \mu \mathrm{m}$ filter. The remaining SVF was stained for flow cytometry.

Adipose tissue lysates for ELISA: Adipose tissue was homogenized in 2mI RIPA buffer containing protease inhibitors and lysed on ice for 30 minutes. Protein lysate was collected and used for ELISA analysis.

Adipose tissue lysates for Western blot: Ten (mg) adipose tissue was homogenized in $250 \mu$ l protein lysis buffer (10\% glycerol, $1 \%$ NP-40, $137 \mathrm{mM}$ $\mathrm{NaCl}, 25 \mathrm{mM}$ HEPES pH 7.4, 1mM EGTA) containing protease inhibitors (Sigma- 
Aldrich) and phosphatase inhibitors (Sigma-Aldrich) and lysed on ice for 30 minutes. Protein lysate was collected and used for Western blot analysis.

\section{Flow Cytometry:}

Red blood cells were lysed if necessary with RBC lysis buffer $\left(155 \mathrm{mM} \mathrm{NH}_{4} \mathrm{Cl}\right.$, $10 \mathrm{mM} \mathrm{KHCO}_{3}, 0.1 \mathrm{mM} \mathrm{Na} 2 \mathrm{EDTA}, \mathrm{pH} 7.4$ ). All cells were strained through $70 \mu \mathrm{m}$ filters and incubated with Fc-block (FCR-4G8, Invitrogen) for 10 minutes on ice prior to staining. Cells were stained on ice and protected from light for 20 minutes. Fc-block and antibodies were diluted in either FACS buffer (PBS containing $1 \% \mathrm{BSA}$ and $0.05 \% \mathrm{NaN}_{3}$ ) for flow cytometry or sorting buffer (PBS containing $1 \% \mathrm{BSA}$ ) for cell sorting experiments. Murine flow cytometry antibodies: B220 (RA3-6B2), CD3ع (145-2C11), CD5 (53-7.3), CD11c (N418), CD19 (1D3), CD21 (4E3), CD23 (B3B4), F4/80 (BM8), and IgM (II/41) were purchased from eBioscience; Annexin V (Cat\# 556420), BrdU (B44), and CD43 (S8) were purchased from BD Bioscience; CD206 (C068C2) was purchased from BioLegend. Human flow cytometry antibodies: CD43 (84-3C1) was purchased from eBioscience, CD3 (5KY), CD20 (L27), CD27 (M-T271), and CD45 (2D1) were purchased from BD Bioscience. Viability was determined by either LIVE/DEAD® fixable yellow cell staining (Invitrogen) or DAPI (Sigma-Aldrich). Cells were run on a CyAN ADP (Beckman Coulter), or sorted on a Reflection Cell Sorter (iCyt) or an Influx Cell Sorter (Benton-Dickenson). Data were analyzed with FlowJo software (Tree Star Inc) using fluorescence minus-one controls for 
gate determination when appropriate. Counting beads (CountBright ${ }^{\mathrm{TM}}$ Absolute Counting Beads, Molecular Probes) were used for quantitation.

Gating strategies: Adipose tissue macrophages ${ }^{174}$, peritoneal and adipose tissue B cells ${ }^{175}$, and splenic B cells ${ }^{176,177}$ were identified as described previously.

\section{ELISA:}

Self-coated ELISAs: 96 well microtiter plates (Corning) were incubated at $4^{\circ} \mathrm{C}$ overnight with capture antibody diluted in coating buffer $(0.1 \mathrm{M}$ disodium phosphate $\mathrm{pH}$ 9.0). Capture antibodies and concentrations for $\lg M$ and $\lg G$ assays: unlabeled lgM (625ng/ml), lgG1 (625ng/ml), lgG2b (1250ng/ml), lgG2c (2500ng/ml), or lgG3 (625ng/ml) (Southern Biotech). For T15-lgM assays: AB1-2 (303ng/ml) (ATCC, HB-33). For PC-lgM assays: PC-BSA $(10 \mu \mathrm{g} / \mathrm{ml})($ Biosearch Tech). Plates were blocked (PBS containing $0.5 \%$ BSA, 0.1\% TWEEN-20, and $0.01 \% \mathrm{NaN}_{3}$ ), incubated with sample, and then treated with IgM or IgG detection antibody conjugated to alkaline phosphatase for two hours at room temperature. Detection antibodies and dilutions used: murine IgM-AP (IgM: 1:8000; T15-IgM: 1:1000), murine IgG-AP (IgG1: 1:8000; IgG2b: 1:4000; IgG2c: 1:4000; IgG3: 1:8000), human IgM-AP (PC-IgM: 1:1000) (all purchased from Southern Biotech). Plates were then developed with pNPP solution (Southern Biotech) for 30-60 minutes and read at 405nm using a SpectraMax 190 (Molecular Devices). IgM and $\lg G$ isotype concentration was determined through a standard curve of purified immunoglobulin (Southern Biotech) using a range of $0.78-200 \mathrm{ng} / \mathrm{ml}$. T15IgM and PC-IgM levels were determined by normalization to serial dilutions of 
standardized mouse (range: 1:50-1:25,600) or human serum (range: 1:50-

$1: 12,800)$, respectively. Serum from $\operatorname{slg}^{-1-}$ or Rag 1 - mice was used as negative controls, and EO6 (Avanti Polar Lipids Inc) was used as a positive control for T15-IgM assays. All dilutions were determined through careful titration, and only values within the range of standard curves with readings at least 3 -fold higher than negative controls were used.

Commercial and previously validated ELISAs and metabolic assays: Mouse TNFa (eBioscience, 88-7324), IFNy (R\&D, MIF00), and FFA (Zen-Bio, SFA-1) levels, along with human MCP-1 (SABiosciences, SEH00192A) levels were determined with commercial kits. IgM-IC, IgG-IC, IgM MDA-LDL, and IgG MDALDL were determined as previously described ${ }^{178}$.

\section{Confocal microscopy}

Epididymal and omental adipose tissue were fixed in $4 \%$ PFA overnight at $4^{\circ} \mathrm{C}$. Samples were blocked and permeabilized for three hours at room temperature in PBS containing $5 \%$ normal rat serum and $0.3 \%$ Triton X-100. Adipocytes were stained with BODIPY Green (Invitrogen) for 20 minutes at room temperature and then with B220-AF647 (BioLegend) at $4^{\circ}$ overnight. Samples were then stained for 20 minutes at room temperature with CYTOX Orange (Invitrogen) for nuclei detection. After washing, samples were mounted in a 50:50 PBS/glycerol solution on gelatin-coated slides. Whole-mounted specimens were imaged by confocal microscopy (Nikon; model TE200-E2). Z-stack Images ( $24 \mu \mathrm{m}$ range, $3 \mu \mathrm{m}$ step) were taken using a 10x objective. Images were adjusted using ImageJ software. 


\section{Omental ex vivo culture}

Murine omental adipose tissue was removed, weighed, and placed in sterile 48 well cell culture plates containing $200 \mu$ media (RPMI-1640, 10\% FBS, Lglutamine, penicillin-streptomycin, $55 \mu \mathrm{M} \beta$-mercaptoethanol). Cultures were incubated overnight (TNF $\alpha$ and IFNy studies) or for four days (T15-IgM studies) and supernatant was collected for ELISA analysis.

\section{B-1b Proliferation and survival study}

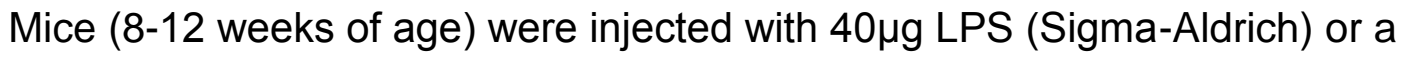
saline vehicle control at $\mathrm{t}=0$. All mice were injected with $1.5 \mathrm{mg} \mathrm{BrdU}$ at $\mathrm{t}=24$ and $t=36$ hours. At $t=48$ hours, mice were euthanized and omental adipose tissue was processed for flow cytometry and stained for B-1b B cell surface markers. Cells were then split into two groups: group 1 was stained for BrdU incorporation using a FITC BrdU Flow Kit (BD Biosciences), and group 2 was stained for Annexin V surface expression in the presence of Annexin V-binding buffer (10mM HEPES pH 7.4, $140 \mathrm{mM} \mathrm{NaCl}, 2.5 \mathrm{mM} \mathrm{CaCl}_{2}$ ). Cells were fixed and analyzed by flow cytometry as described above.

\section{Western blot}

Protein lysates were supplemented with $11 \% \beta$-mercaptoethanol and $0.5 \%$ bromophenol blue. Samples were resolved on 4-20\% Tris-glycine gels (Invitrogen) and transferred to a polyvinylidene difluoride membrane (BioRad). 
Western blotting was carried out using an antibody against Thr308 pAKT (1:1,000, Cell signaling) or AKT $(1: 1,000$, Cell signaling), followed by horseradish peroxidase-linked secondary antibody (Jackson). Immunoreactive bands were visualized by enhanced chemiluminescence after incubation with $E C L$ or ECL plus reagent (Amersham Pharmacia Biotech). Relative AKT phosphorylation was determined by normalizing PAKT to total AKT in each sample.

\section{Human studies}

Patients were recruited through the Bariatric Surgery Clinic at the University of Virginia. All patients were $\geq 18$ years of age and obese $(\mathrm{BMI} \geq 30)$, and provided informed written consent prior to participation in the study. The study was approved by the Human IRB Committee at the University of Virginia, and all procedures were in accord with the declaration of Helsinki. Patients were divided into two groups, and both cohorts of bariatric patients were consented under the same criteria at UVA. Cohort 1 represents patients where we performed flow cytometry on fresh adipose tissue and blood (surgery dates between October, 2012 and October, 2013). Blood, subcutaneous adipose tissue, and omental adipose tissue were collected and processed within two hours and analyzed by flow cytometry. Cohort 2 represents patients from whom frozen tissue samples were analyzed by ELISA (surgery dates between May, 2009 and August, 2010). Metabolic syndrome was defined as any three of the following: large waist circumference (men: >40in; women: >35in), hypertension, low HDL (men: $<40 \mathrm{mg} / \mathrm{dl}$; women: $<50 \mathrm{mg} / \mathrm{dl}$ ), high triglcyerides (>150mg/dl), high blood glucose 
(>100mg/dl) In all patients, pre-operative creatinine and blood glucose values were used. Serum was stored for future ELISA analysis and/or NMR lipid analysis (LipoScience Inc).

\section{Statistics}

For mouse data, a student's t-test was performed on data with normal distribution and equal variance. If data sets had unequal variance, a t-test with Welch's correction was used. For non-Gaussian distributed data, a Mann-Whitney test was performed to determine statistical significance. For comparisons of three or more independent variables, a one-way ANOVA test was used with a KruskalWallis post-hoc test. Results are displayed containing all replicated experiments, and values shown are mean \pm SEM unless otherwise noted. For human clinical data, baseline characteristics are reported as mean \pm standard deviation for normally distributed variables, and as median with interquartile range for nonnormally distributed variables. Spearman correlation coefficients were used to determine the strength of association between variables. Data were analyzed with Prism 6.0a (GraphPad Software, Inc.) or SAS 9.3 and displayed using Prism 6.0a. 


\section{CHAPTER 3:}

Loss of $I d 3$ in B-1b B cells attenuates high-fat diet-induced glucose intolerance 


\section{Introduction}

Obesity is an epidemic in the Western world, and dramatically increasing rates in developing countries have made it one of the prominent global health concerns of the $21^{\text {st }}$ century. Obesity-induced visceral adipose tissue (VAT) inflammation leads to systemic insulin resistance and glucose intolerance ${ }^{11}$. While macrophages and T cells have been implicated in this process ${ }^{70,72}$, emerging evidence suggests that B cells also modulate obesity-induced adipose tissue inflammation and insulin resistance.

$B$ cells have been identified in murine and human adipose tissue ${ }^{76,78,79,81,}$ $82,141,179$, and localize to sites of inflammation ${ }^{80}$. Recently, IgG, but not IgM, from DIO mice was shown to drive adipose tissue inflammation and promote systemic insulin resistance ${ }^{81}$. These pathogenic lgG antibodies were localized in VAT and came from adaptive B-2 B cells - the major B cell subset that differentiate into memory B and plasma cells capable of producing class-switched, high affinity antibodies $^{180,181}$. In mice, the majority of IgM derives from B-1 B cells, a selfrenewing innate B cell population that differ from B-2 cells in response to stimuli and antibody repertoire ${ }^{96}$. B-1 B cells protect against early infection and are further divided into B-1a and B-1b subsets that have overlapping functions, but exhibit differences in activation and response to infection ${ }^{92-95}$. While B-1 B cells have known anti-inflammatory properties and are found in similar proportions within adipose tissue as B-2 B cells ${ }^{81}$, their role(s) in mediating obesity-induced adipose tissue inflammation and insulin resistance remains unknown. 
A major proportion of B-1-derived IgM are termed "natural antibodies" as they arise without previous antigen exposure and contain few mutations or $\mathrm{N}$ additions $^{182}$. IgM is less immunogenic than $\lg ^{121}$ and natural antibodies often recognize epitopes expressed on both invading pathogens and damaged selfcells ${ }^{182,183}$, providing dual roles in curbing inflammation and promoting tissue homeostasis. Among the many known natural antibodies, the best studied are members of the $T 15$ family that bind phosphocholine $(P C)^{115}$, an epitope present on pneumococcal cell membranes as well as on oxidized phospholipids of oxidized LDL and apoptotic cells ${ }^{116}$. T15 natural IgM antibodies (T15-IgM or PC$\lg M)$ have direct and indirect anti-inflammatory functions ${ }^{119,120,184}$, and are thought to protect in specific instances of diet-induced chronic inflammation ${ }^{184 \text {, }}$ 185. IgM antibodies localize to areas of adipose tissue inflammation ${ }^{81}$, yet it is unclear whether they are produced locally or if they serve any role in mediating the metabolic dysfunction brought on by obesity.

The HLH protein $I d 3$ is a ubiquitously expressed dominant-negative transcription regulator that, along with its binding partners, mediates various stages of B cell development and function ${ }^{154,158}$. Mice globally null for Id 3 have impaired antigen-specific antibody responses ${ }^{158}$ and increased levels of circulating $\lg ^{162,163}$. Recent work from our group has shown a role for Id3 in $\mathrm{B}$ cell regulation of diet-induced chronic inflammation ${ }^{162,186}$. Additional studies using a mouse model of obesity showed that mice with global deletion of Id 3 are protected against diet-induced VAT expansion ${ }^{164}$. Together, these findings suggest $l d 3$ may be a key factor that links B cell function and obesity. 


\section{$\underline{\text { Results }}$}

\section{B cell specific deletion of Id3 leads to improved diet-induced glucose intolerance.}

To evaluate whether $l d 3$ expression is important for B cell-mediated effects of obesity, mice null for Id3 specifically in B cells (Id3 $\left.{ }^{\mathrm{Bcell}} \mathrm{KO}\right)$ and WT littermates were fed either chow or HFD for 12 weeks. No genotype-dependent differences in epididymal adipose tissue mass, body weight, or serum FFA levels were detected (Figure 6A). Insulin tolerance tests (ITT) revealed that while Id3 ${ }^{\text {Bcell }}$ KO mice fed a HFD displayed a slightly improved initial response to insulin compared to HFD WT controls, this difference did not persist throughout the experimental time course, suggesting little differences in systemic insulin resistance (Figure 6B). Interestingly however, administration of glucose tolerance tests (GTT) showed that Id3 ${ }^{B c e l l ~ K O}$ mice fed HFD did have improved glucose clearance compared to controls (Figure $6 \mathrm{C}$ ), suggesting a role for $I d 3$ in B cell regulation of HFD-induced metabolic dysfunction.

To test whether these findings stem from loss of $l d 3$ function in a B-2 cell, we performed adoptive transfers of splenic B-2 B cells into B cell-deficient $\mu \mathrm{MT}$ hosts. $\mu \mathrm{MT}$ mice contain a deletion in the mu heavy chain that is required for surface BCR expression and is essential for both B-1 and B-2 development ${ }^{187}$. As a previous study demonstrated that B-2 B cells only impact systemic metabolism when derived from a DIO mouse and injected into DIO hosts ${ }^{81}$, ten million splenic B-2 cells isolated from HFD-primed WT or $1 d 3^{-/}$donors were 

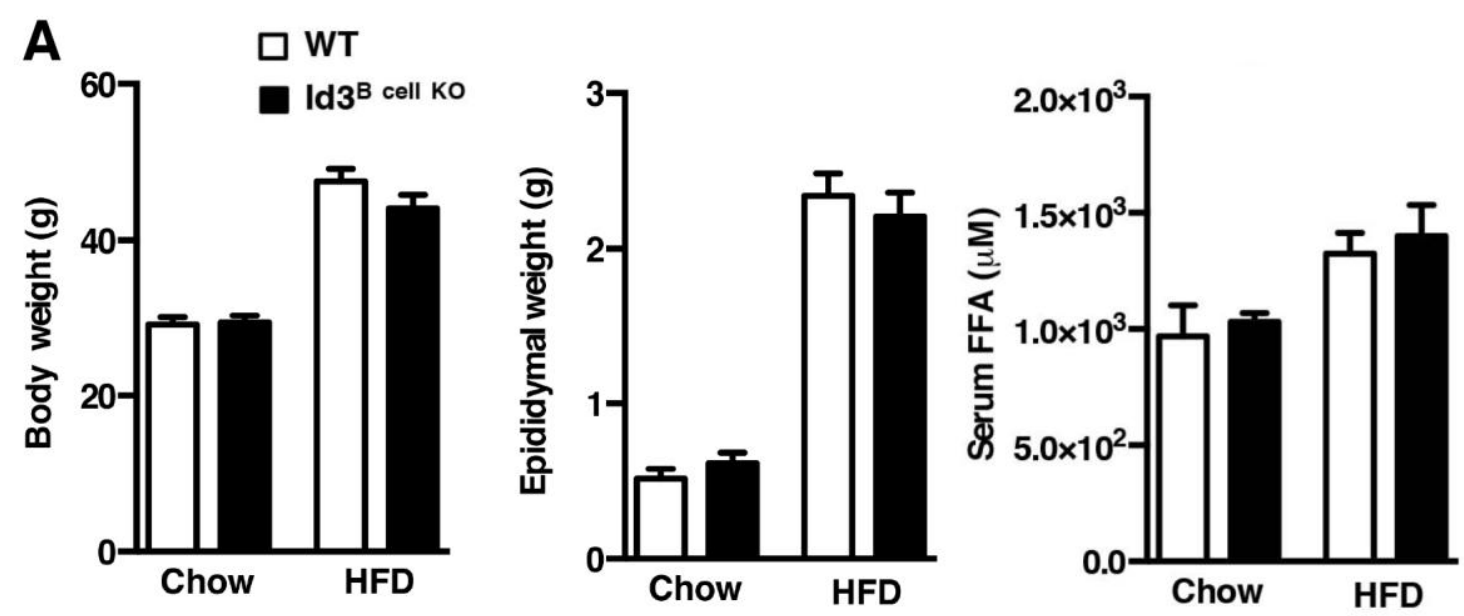

B

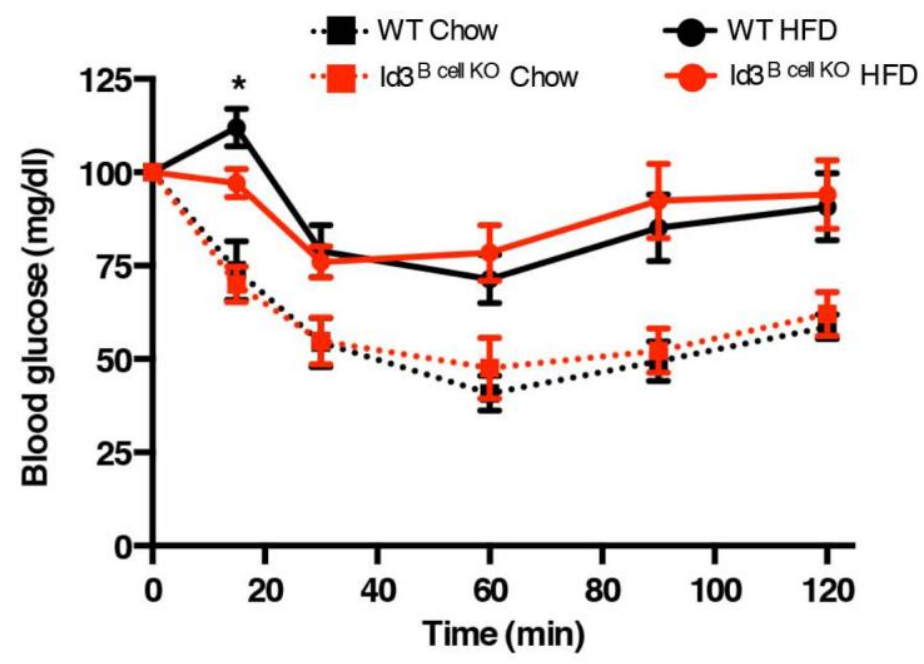

C

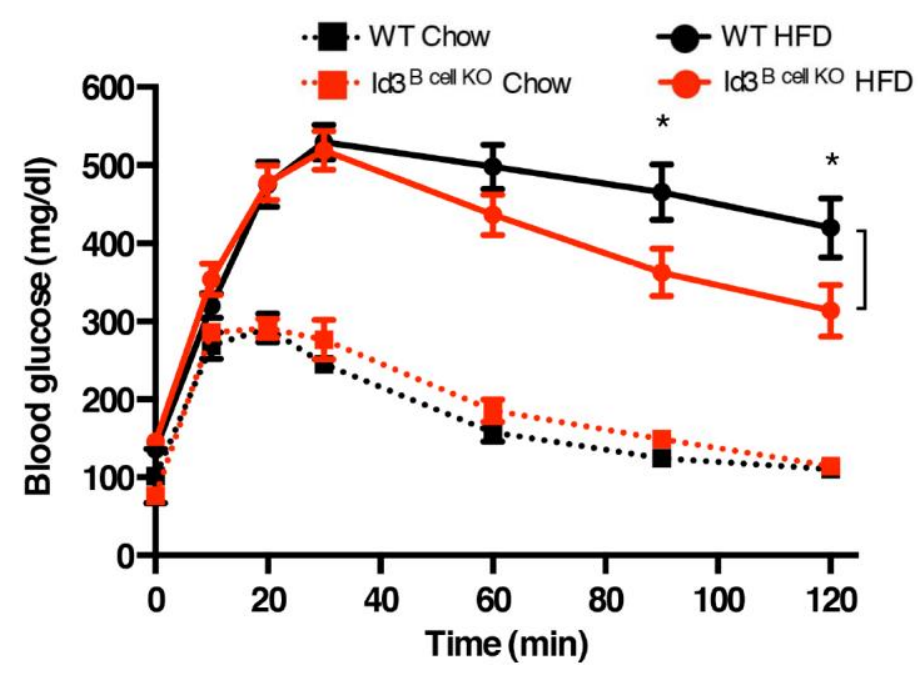


Figure 6. Loss of Id3 in B cells attenuates HFD-induced glucose intolerance. Id $3^{\mathrm{Bcell}} \mathrm{KO}$ and $\mathrm{WT}$ littermates were fed standard chow (WT $\mathrm{n}=6-7$;

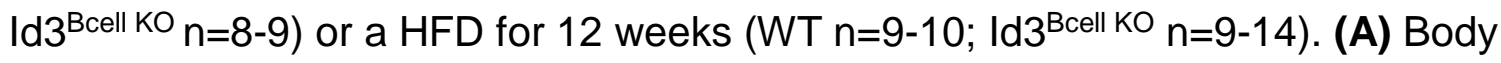
and epididymal adipose tissue weights, and serum FFA levels. (B) Insulin tolerance test. (C) Glucose tolerance test. Error bars represent \pm SEM. ${ }^{*} p<0.05$. 
injected i.p. into $\mu \mathrm{MT}$ mice that had been fed a HFD for eight weeks. Recipient mice, including a control that received a vehicle saline injection, were continued on a HFD and tested for glucose tolerance at two and six weeks post-transfer (Figure 7A). At the end of the experiment, viable B cells were found in adoptive transfer hosts, and there were no Id3-dependent variations in recovery number (Figure 7B). While no differences in body mass or epdidymal adipose tissue were observed (Figure 7C), and all three groups demonstrated similar glucose tolerance at week two (Figure 7D), WT hosts had significantly impaired glucose clearance compared to vehicle controls six weeks post-transfer (Figure 7D). This corroborates previous findings ${ }^{81}$ that $\mathrm{B}-2$ cells impair glucose homeostasis. However, hosts receiving WT and Id $3^{-/}$B-2 cells had nearly identical glucose clearance patterns (Figure 7D), providing evidence that improved glucose tolerance in Id $3^{\mathrm{Bcell}} \mathrm{KO}$ mice is not due to loss of $I d 3$ function in a B-2 B cell, and suggesting other B cell subsets may modulate obesity associated metabolic dysfunction.

\section{Id3 ${ }^{B c e l l}$ KO mice fed a HFD have increased B-1 B cells, total IgM, and T15-IgM natural antibodies in adipose tissue.}

Immune cells within adipose tissue can impact glucose homeostasis in a subset-dependent manner ${ }^{70,72}$ Flow cytometry studies in epididymal fat from DIO Id $3^{\text {Bcell KO }}$ mice revealed no differences in $\mathrm{F} 4 / 80^{+} \mathrm{CD} 206 \mathrm{CD}^{-\mathrm{C} 11 \mathrm{C}^{+} \mathrm{M} 1 \text { or }}$

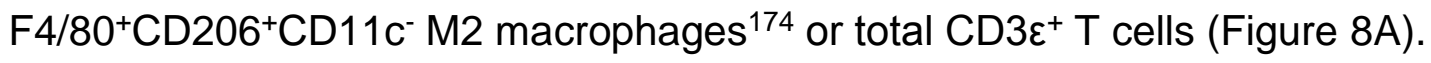


A

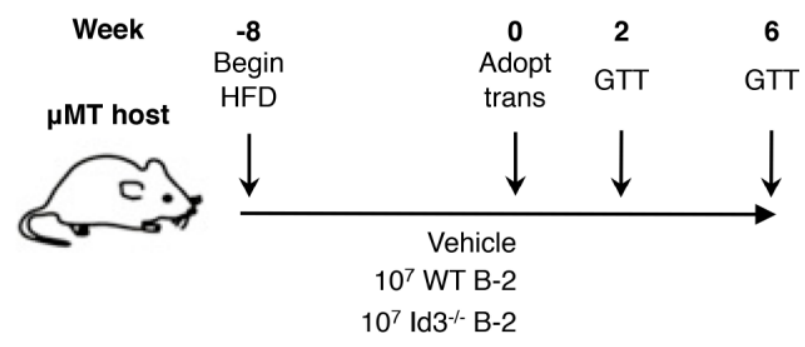

B

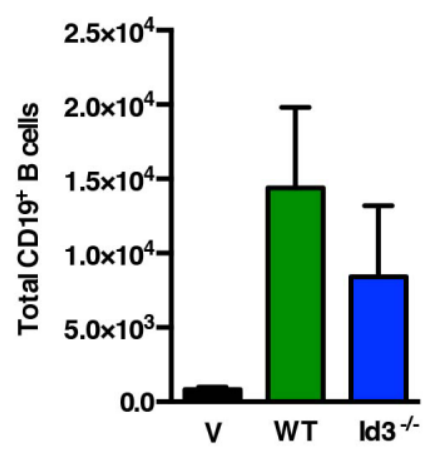

C
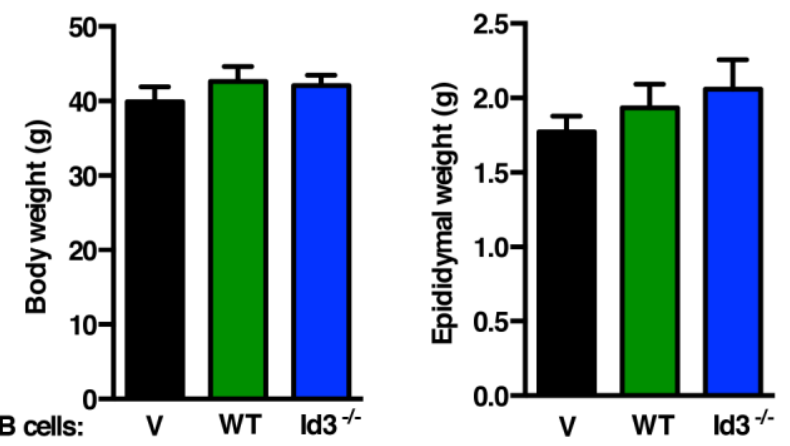

D
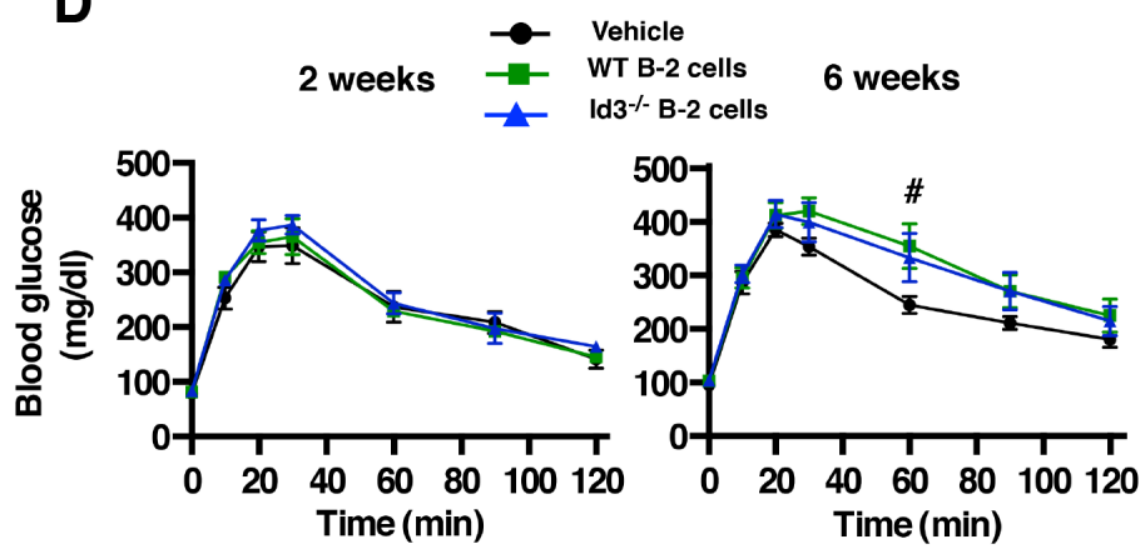
Figure 7. Id 3 not is required for B-2 B cell driven glucose intolerance in DIO $\mu M T$ mice. (A) DIO $\mu M T$ mice received either an i.p. vehicle $(V, n=6)$ saline injection or adoptive transfer of $10^{7}$ B-2 cells from DIO WT $(n=7)$ or $/ d 3^{-}(n=7)$ donors and were continued on HFD for six additional weeks. (B) B cells recovered in epididymal adipose tissue after week 6. (C) Body and epididymal adipose tissue weights. (D) GTT at two (left panel, representative of two independent experiments) and six (right panel, composite of two independent experiments) weeks post-transfer. Error bars represent \pm SEM. $\# p<0.05$ WT vs. V. 
A $\square$ WT $\square$ ld3 $3^{\text {B cell ко }}$

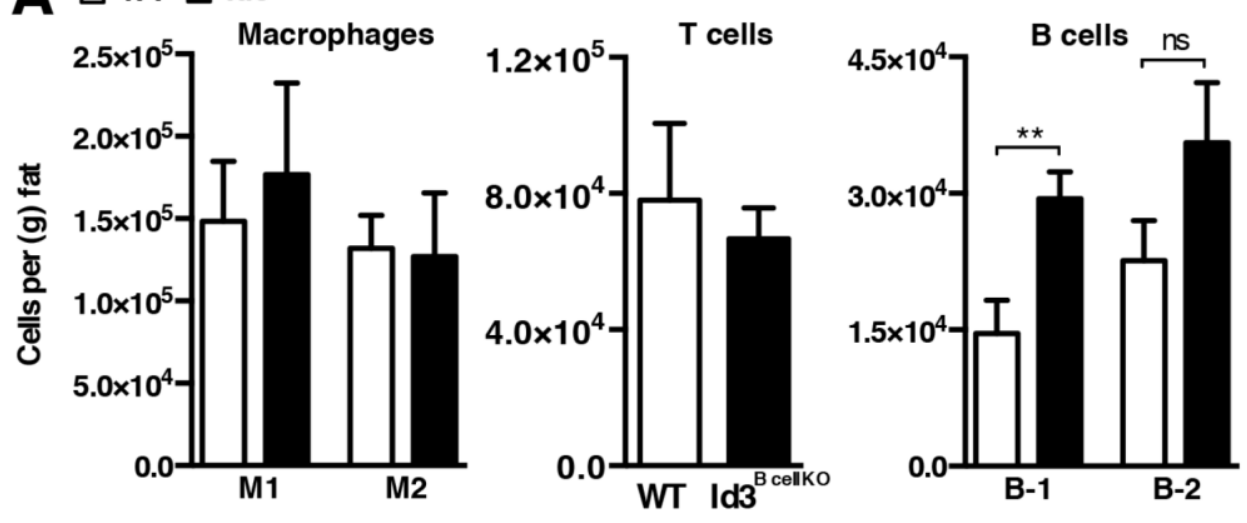

B $\square$ WT $\square$ Id3 $3^{B}$ cell кo

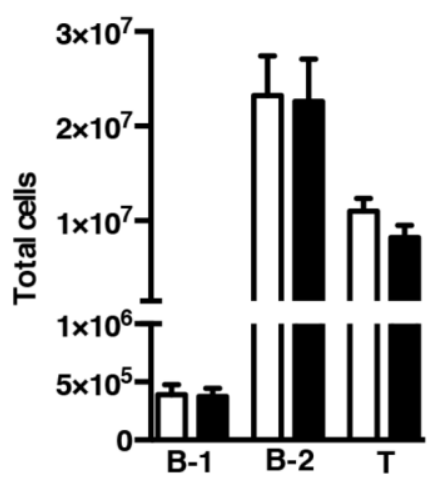


Figure 8. Adipose tissue-specific increases of B-1 B cells in Id $3^{\mathrm{Bcell}} \mathrm{KO}$ mice fed a HFD. Id $3^{B c e l l} \mathrm{KO}$ and WT littermates were fed a HFD for 12 weeks. Flow cytometry analysis of (A) epididymal adipose tissue $\mathrm{F} 4 / 80^{+} \mathrm{CD} 206^{-} \mathrm{CD} 11 \mathrm{C}^{+} \mathrm{M} 1$ and F4/80 ${ }^{+}$CD206 ${ }^{+}{ }^{C D 11 c^{-}}$M2 macrophages (left panel, WT $n=6$; Id3 ${ }^{\text {Bcell KO }} \mathrm{n}=6$ ), CD $3 \varepsilon^{+}$T cells (middle panel, WT $n=8$; Id $3^{B c e l l} K O n=11$ ), and $B 220^{\text {mid/lo }} C D 19^{\text {hi }} B-1$ and B220 ${ }^{\text {hi } C D 19 m i d / l o ~} B-2 B$ cells (right panel, $W T n=6$; $I d 3^{B c e l l} K O n=8$ ). (B) Splenic B-1 and B-2 $B$ cells (WT $n=6$; Id $3^{B c e l l} K O n=8$ ) and T cells (WT $n=8$; Id $3^{\text {Bcell } K O}$ $\mathrm{n}=11)$. Error bars represent \pm SEM. ${ }^{* *} p<0.01$. 
There was a trend toward an increase in B-2 cells, although this change did not reach statistical significance. In contrast, Id $3^{\mathrm{Bcell}} \mathrm{KO}$ mice had significantly elevated numbers of B-1 B cells within epididymal fat compared to WT littermates (Figure 8A). No differences were observed in splenic B-1 B cells, B-2 B cells, or T cells (Figure 8B), suggesting that Id3-dependent regulation of B-1 cells may be tissuespecific.

B-1 B cells are a major source of natural IgM antibodies, including PCrecognizing $\mathrm{T} 15-\lg \mathrm{M}$, that promote tissue homeostasis and attenuate inflammation ${ }^{115,116,119-121,182-185 . ~ E p i d i d y m a l ~ a d i p o s e ~ t i s s u e ~ I g M ~(F i g u r e ~ 9 A) ~ a n d ~}$ T15-IgM (Figure 9B) levels were elevated in DIO Id3 $3^{\mathrm{Bcell}} \mathrm{KO}$ mice compared to WT. Neither varied significantly in the circulation, suggesting that differences in adipose tissue were not just a reflection of elevated systemic production. Furthermore, we observed no variations in circulating or adipose tissue $\lg G$ antibodies (Table 1). Together, findings demonstrate that loss of $I d 3$ in B cells leads to increased adipose tissue B-1 B cell numbers and local natural IgM antibodies.

\section{Loss of Id3 in B cells leads to elevation of peritoneal and adipose tissue B- $1 \mathrm{~b}$ B cells and increased omental T15-IgM production.}

The majority of B-1 B cells are found in the peritoneal cavity and the spleen and can be divided into $\mathrm{CD} 5^{+} \mathrm{B}-1 \mathrm{a}$ and $\mathrm{CD} 5^{-} \mathrm{B}-1 \mathrm{~b}$. Since both are capable of producing natural antibodies ${ }^{96}$ many studies do not distinguish 
A
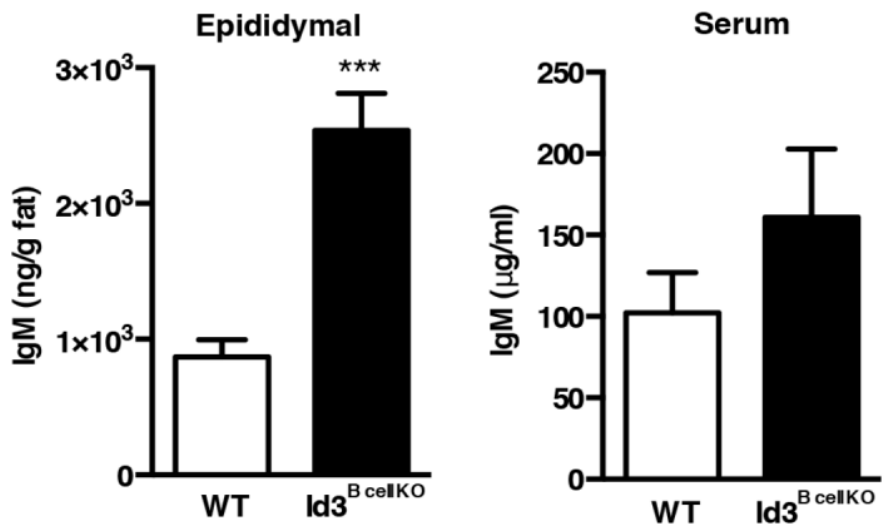

B
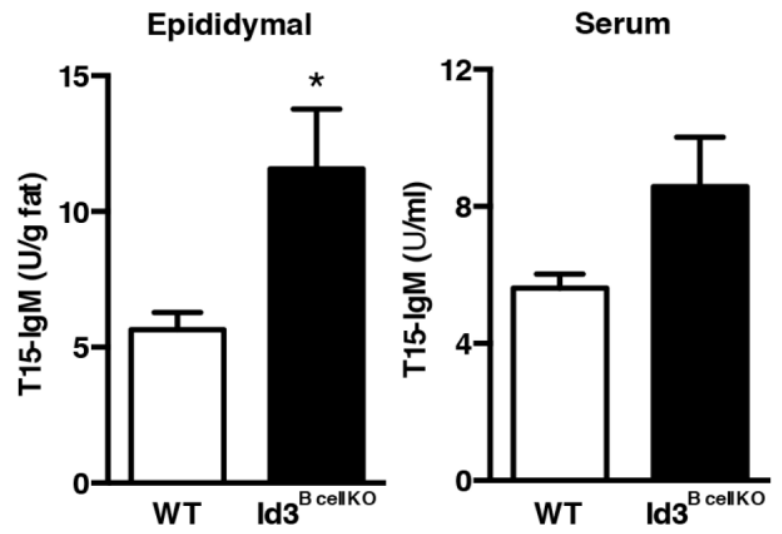
Figure 9. Adipose tissue-specific increases in total IgM and T15 natural IgM antibodies in Id $3^{\text {Bcell KO }}$ mice fed a HFD. Id $3^{B c e l l ~ K O}(n=6)$ and WT $(n=6)$ littermates were fed a HFD for 12 weeks. (A) Total IgM by ELISA in epididymal adipose tissue (left panel) and serum (right panel). (B) T15-specific IgM by ELISA in epididymal adipose tissue (left panel) and serum (right panel). Error bars represent \pm SEM. ${ }^{*} p<0.05,{ }^{* * *} p<0.001$. 
Table 1. IgG antibody levels in serum and epididymal fat of mice fed a HFD for 12 weeks.

\begin{tabular}{llll}
\hline & WT $(\mathrm{n}=6)$ & $\operatorname{Id}^{\mathrm{B} \text { cell KO }}(\mathrm{n}=6)$ & $\mathrm{p}$-value \\
\hline Serum $(\mu \mathrm{g} / \mathrm{ml})$ & & & \\
$\operatorname{lgG} 1$ & $51.7 \pm 8.2$ & $33.2 \pm 4.4$ & 0.0742 \\
$\operatorname{lgG2b}$ & $137.2 \pm 8.3$ & $121.5 \pm 16.9$ & 0.4246 \\
$\operatorname{lgG2c}$ & $92.3 \pm 12.3$ & $67.1 \pm 9.0$ & 0.1277 \\
IgG3 & $45.4 \pm 5.4$ & $77.6 \pm 23.6$ & 0.2363 \\
Epididymal fat (ng/g fat) & & & \\
IgG1 & $1914 \pm 203$ & $1433 \pm 423$ & 0.3295 \\
IgG2b & $4054 \pm 495$ & $4053 \pm 759$ & 0.9988 \\
IgG2c & $1729 \pm 157$ & $1852 \pm 322$ & 0.7376 \\
IgG3 & $2345 \pm 706$ & $4514 \pm 1572$ & 0.2365 \\
Values presented as mean \pm SEM & &
\end{tabular}


between the two. However, B-1a and B-1b B cells exhibit differences in activation and response to infection ${ }^{92-95,182}$, indicating they likely have differing functions. Peritoneal fluid from Id3 ${ }^{\mathrm{Bcell}} \mathrm{KO}$ mice was analyzed to distinguish whether elevated B-1 numbers in the absence of $I d 3$ was due to an overall increase in both subsets, or a specific increase in one. Interestingly, Id3 ${ }^{\mathrm{Bcell}} \mathrm{KO}$ mice displayed a three-fold increase in peritoneal B-1b B cells, but no difference in B-1a B cells (Figure 10A). Similar to our initial findings (Figure 8), no differences in B-1a, B1b, FO, or MZ B cell subsets were identified in the spleen (Figure 10B, data not shown). The Id $3^{\text {Bcell KO }}$ mouse contains only one functional CD19 allele. As alterations of CD19 expression specifically impact B-1b B cell number ${ }^{94}$, analysis of peritoneal fluid from $1 d 3^{++} C D 19$ Cre/+ mice confirmed that our findings were due to deletion of Id3 in B cells and not CD19 haploinsufficiency (Figure 11).

Similar to findings in the peritoneal fluid, loss of $I d 3$ in B cells also led to a specific increase in B-1b B cell numbers within epididymal (Figure 12A) and omental (Figure 12B) adipose tissue. Consistent with previous reports ${ }^{82}$, substantially more B-1 B cells were found in omental fat than epididymal fat relative to tissue mass (Figure 12A \& B), and only omental adipose tissue contained MS clusters that stained heavily for the B cell marker B220 (Figure 12C). In addition, omental fat cultured ex vivo from Id $3^{\text {Bcell KO }}$ mice produced three-fold more T15-IgM than controls (Figure 12D), providing evidence that natural IgM is produced in omental adipose tissue in proportion to the number of $\mathrm{B}-1 \mathrm{~b}$ cells. Together, our findings indicate that $l d 3$ is an important regulator of 
A
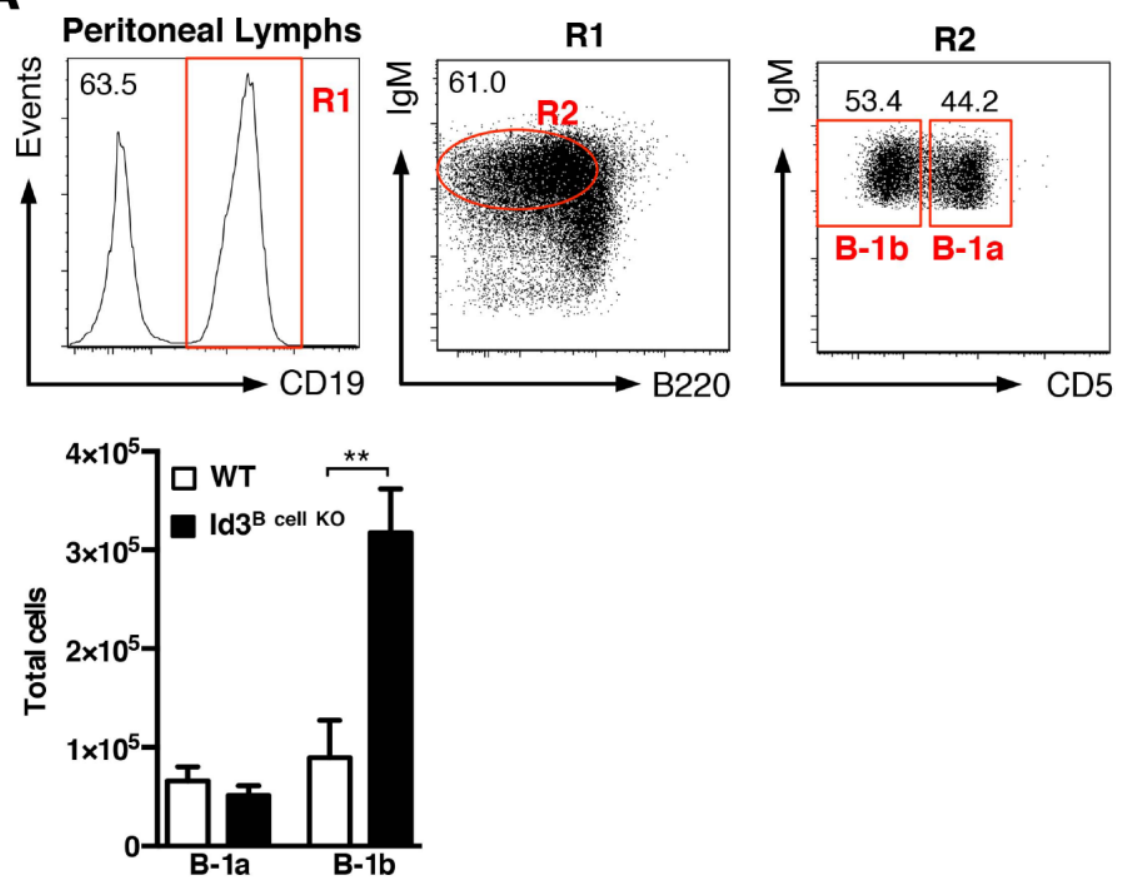

\section{B}
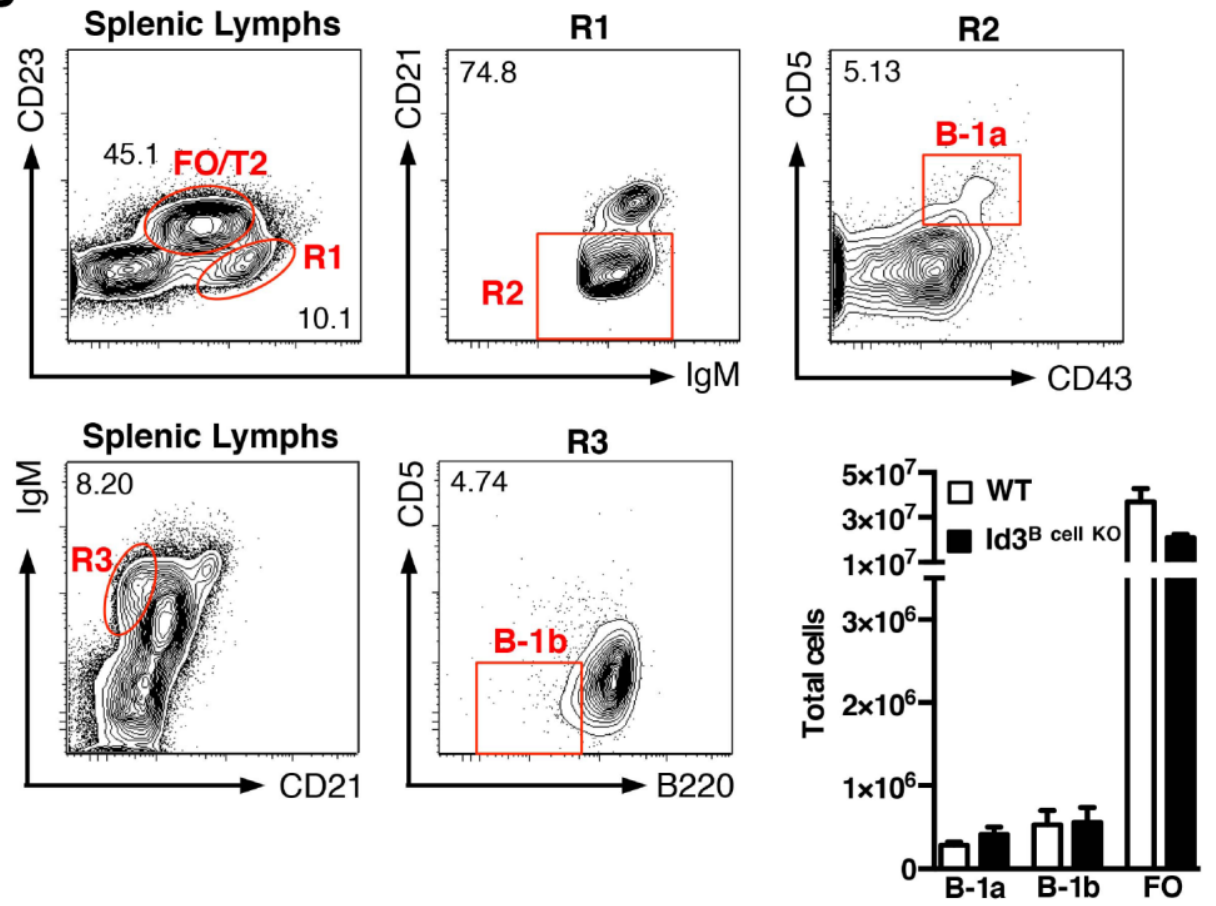
Figure 10. Peritoneal B-1b B cells are elevated in chow-fed Id $3^{\text {Bcell KO }}$ mice.

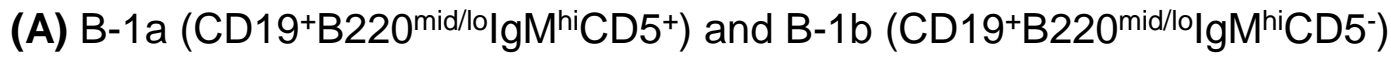
gating strategy (top) and cell numbers (bottom) in peritoneal fluid of WT $(n=5)$ and Id3 ${ }^{B c e l l ~ K O}(n=8)$ mice. (B) B-1a (CD23-lgM ${ }^{\text {hi }}$ CD21-CD43+CD5+), B-1b

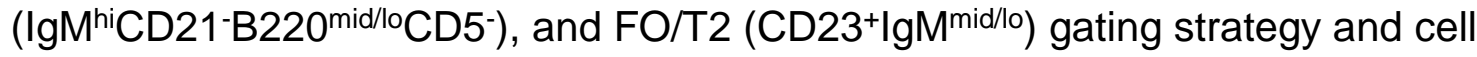
numbers in spleens of WT $(n=5)$ and Id $3^{B c e l l ~ K O}(n=8)$ mice. Error bars represent \pm SEM. ${ }^{* *} p<0.01$. 


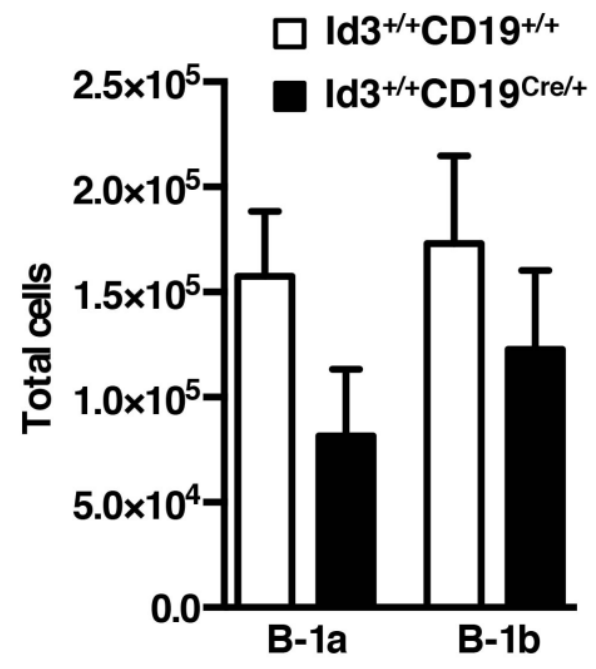


Figure 11. No difference in Id $3^{+/+}$CD19Cre/+ peritoneal B-1a or B-1b B cells. Flow cytometry analysis of peritoneal fluid B-1a (CD19+B220 mid//olgMhi $\left.{ }^{\text {hi }}{ }^{+} 5^{+}\right)$and

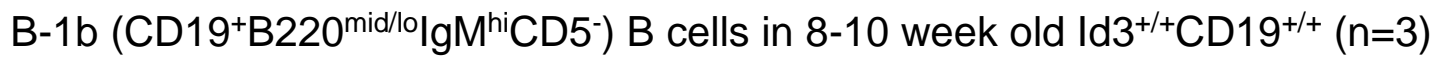
and $I d 3^{+/+} C D 19^{C r e /+}(n=3)$ littermates. 
A

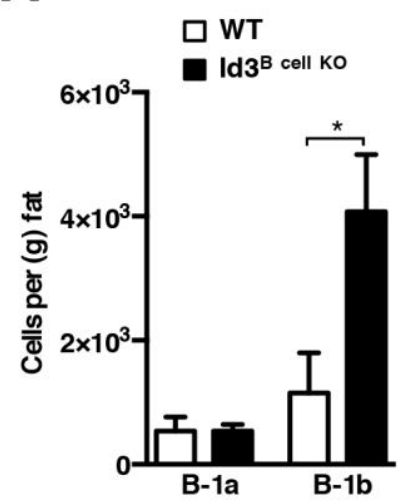

C

Lymphocytes B220 BODIPY

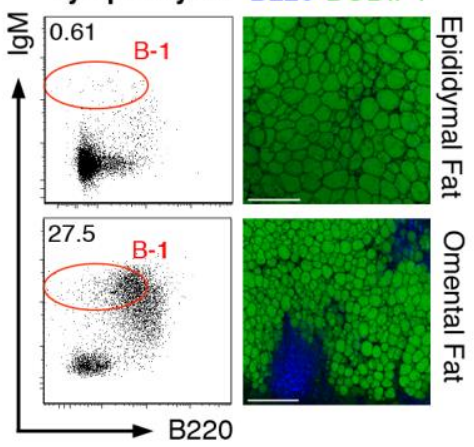

B

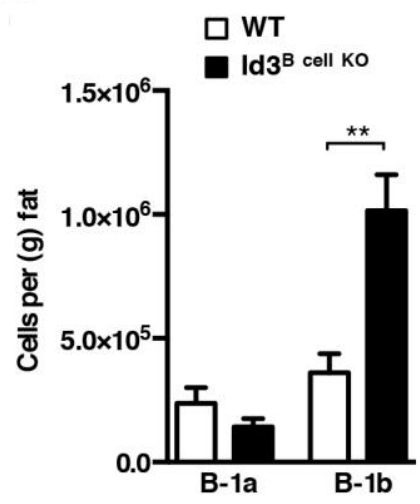

D

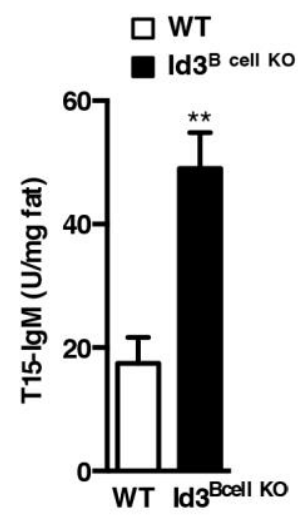


Figure 12. Loss of $I d 3$ in B cells leads to increased adipose tissue B-1b B cells and IgM secretion in chow-fed mice. (A) Epididymal B-1a and B-1b B cells in 8-10 week old Id3 ${ }^{B c e l l} \mathrm{KO}(n=8)$ and WT $(n=5)$ littermates. (B) Omental B$1 \mathrm{a}$ and B-1b B cells in 8-10 week old Id $3^{\text {Bcell } K O}(n=7)$ and WT $(n=5)$ littermates (C) Representative flow cytometry and 10x confocal microscopy images of murine epididymal (top panels) and omental (bottom panels) adipose tissue. Scale bar $=200 \mu \mathrm{m}$. (D) T15-specific IgM in supernatant of Id3Bcell KO $(n=3)$ and WT $(n=4)$ omental adipose tissue cultures. Error bars represent \pm SEM. ${ }^{*} p<0.05$, ${ }^{* *} p<0.01$. 
adipose tissue B-1b B cell population size, and that loss of Id 3 leads to significantly more B-1b B cells and subsequently elevated local natural IgM production.

\section{Loss of Id3 promotes omental B-1b B cell survival}

B-1 B cells survive better than B-2 B cells and have the ability to selfrenew, allowing for self-governing population maintenance. Our findings in the Id $3^{B c e l l} \mathrm{KO}$ mouse that loss of $I d 3$ leads to elevated B- $1 \mathrm{~b}$ B cell number in adipose tissue suggest dysregulated mature B-1b B cell population maintenance. However, it is also possible that $I d 3$ deficiency leads to accelerated B-1b development. To test whether $I d 3$ regulates population maintenance in mature B1b B cells, we adoptively transferred equivalent numbers $\left(8.0 \times 10^{4}\right)$ of

fluorescence-activated cell sorted (FACS) mature B-1b B cells from WT or Id3 $3^{\text {Bcell }}$ KO donors into B and T cell-deficient Rag1\% hosts. Rag 1\% mice were used instead of $\mu \mathrm{MT}$ mice because B-1 B cells do not survive after i.p. transfer into $\mu \mathrm{MT}$ mice ${ }^{188}$. Three weeks after transfer, we confirmed a B-1b B cell population within omental fat (Figure 13A). Moreover, there were a significantly greater number of omental fat B-1b B cells if the donor cells were null for Id3. This indicates that the enhanced $\mathrm{B}-1 \mathrm{~b} B$ cell numbers in Id $3^{\mathrm{Bcell}} \mathrm{KO}$ mice is intrinsic to loss of $I d 3$ in mature B-1b B cells.

Population maintenance depends on a balance between cell proliferation and cell death, and increased cell numbers can result from defective regulation of 


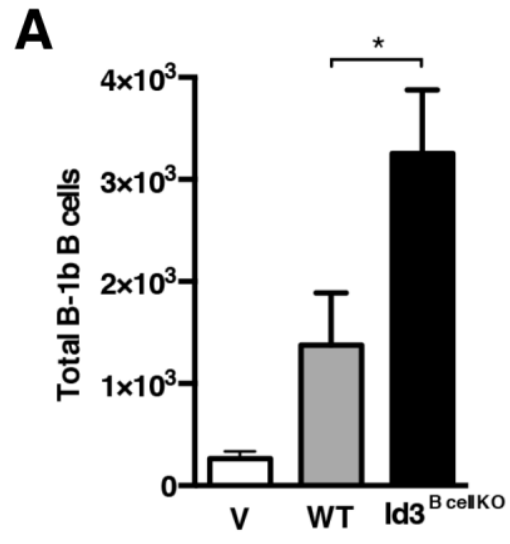

B

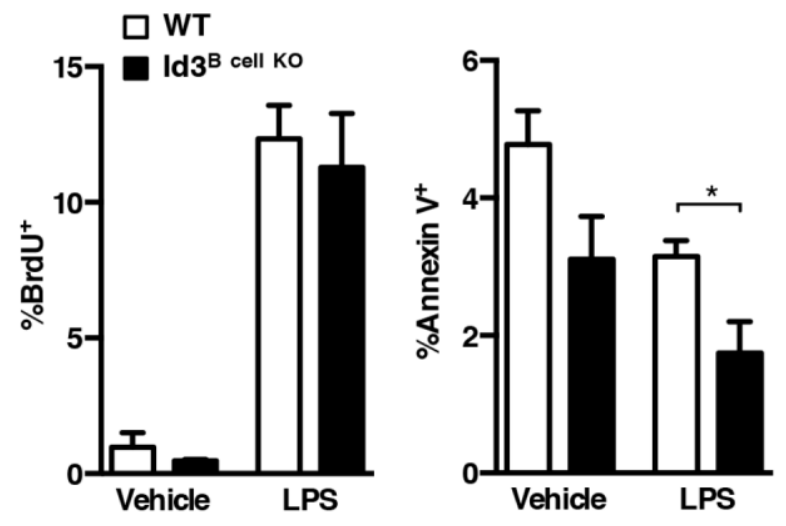


Figure 13. Id 3 regulates survival in mature $B-1 b$ B cells. (A) B-1b $B$ cells recovered in omental fat three weeks after adoptive transfer of $80 \mathrm{kWT}$ or Id3 $3^{\mathrm{Bcell}}$

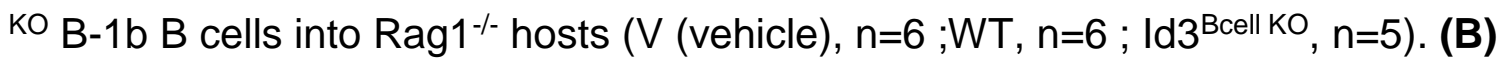
BrdU incorporation (left) and Annexin $V$ staining (right) of $B-1 b$ B cells from WT and Id $3^{B c e l l ~ K O}$ mice treated with vehicle $(n=3-4)$ or $40 \mu \mathrm{g}$ LPS $(n=5-7)$. Error bars represent \pm SEM. ${ }^{*} p<0.05$. 
either process. To test whether $I d 3$ mediates proliferation or survival in $\mathrm{B}-1 \mathrm{~b} \mathrm{~B}$ cells, WT and Id3 ${ }^{\text {Bcell KO }}$ mice were injected with LPS - a rapid B-1b activator ${ }^{189}$. Mice were then injected with BrdU to label proliferating cells, and B-1b B cells in omental fat were analyzed for proliferation and survival. LPS-activated B-1b B cells in omental adipose tissue displayed no Id3-dependent differences in BrdU incorporation (Figure 13B). However, loss of $I d 3$ in B cells led to lower Annexin V staining in omental B-1b B cells in LPS-treated mice (Figure 13B). This indicates reduced apoptosis, and suggests that $I d 3$ is an important mediator of $B-1 b$ B cell survival.

\section{Attenuated HFD-induced inflammation and insulin resistance in omental adipose tissue of Id $3^{B c e l l}$ KO mice.}

Omental fat of Id $3^{B c e l l ~ K O}$ mice contains higher numbers of $B-1 b$ B cells and produces more anti-inflammatory T15-IgM antibodies, suggesting that loss of Id3 in B cells may attenuate HFD-induced adipose tissue inflammation. To test this hypothesis, WT and Id $3^{B c e l l} \mathrm{KO}$ mice were fed a HFD for two weeks, and inflammatory cytokines secretion in omental adipose tissue was evaluated. Indeed, omental fat from Id $3^{\mathrm{Bcell}} \mathrm{KO}$ mice displayed attenuated diet-induced inflammation as there was significantly less TNFa and IFNy produced compared to diet-matched WT controls (Figure 14A). There were no genotype-dependent differences in chow-fed animals, suggesting that the local anti-inflammatory function may only occur in response to elevated inflammatory activity, such as 

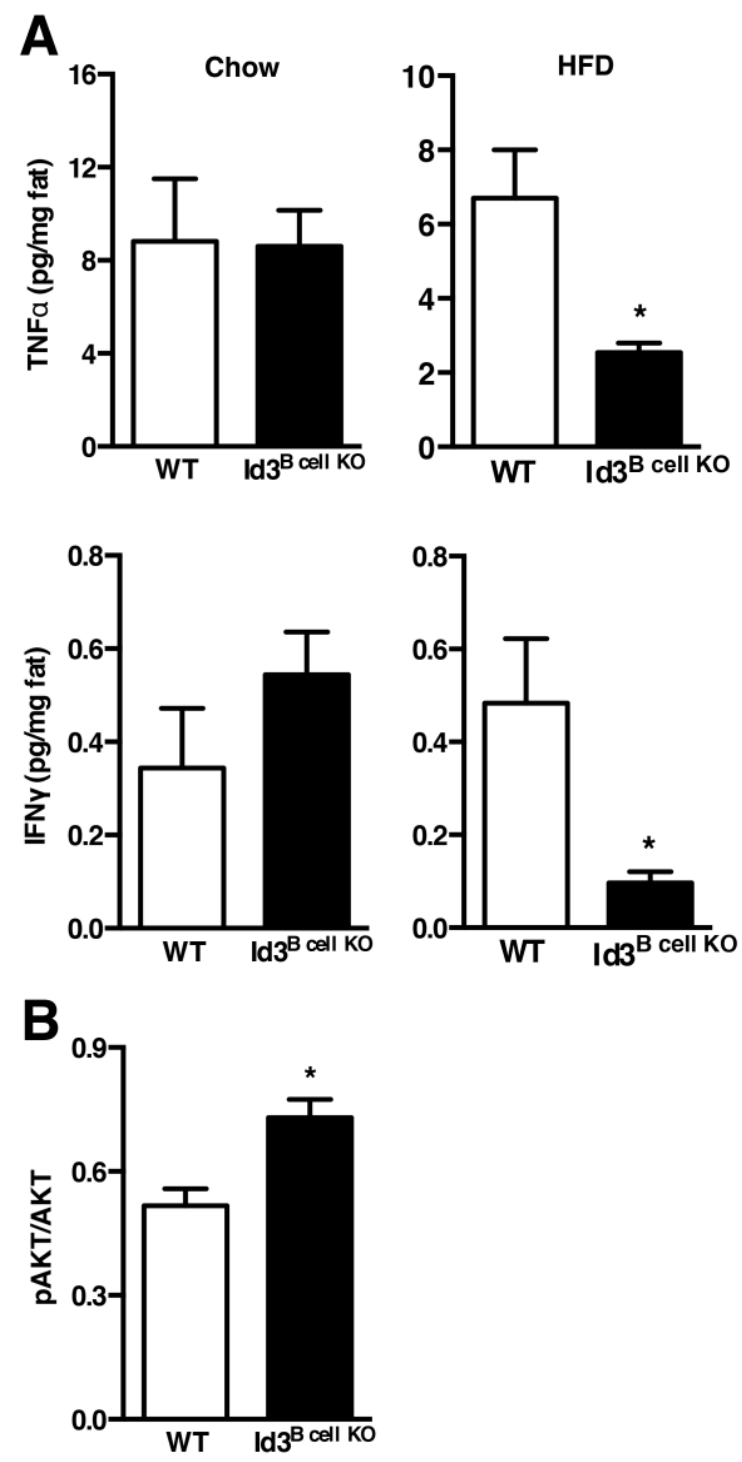
Figure 14. Loss of Id3 in B cells leads to reduced inflammation and improved insulin sensitivity in omental fat of mice fed a short-term HFD. (A) WT and Id $3^{\text {Bcell KO }}$ littermates were fed chow ( $\left.n=4-5\right)$ or a HFD ( $\left.n=5-7\right)$ for two weeks. TNF $\alpha$ (top) and IFN $\gamma$ (bottom) ELISA analysis of supernatant of omental adipose tissue cultures from chow-fed (left) and HFD-fed (right) mice. (B) AKT phosphorylation normalized to total AKT in omental fat five minutes after insulin injection in WT $(n=3)$ and Id3 ${ }^{B c e l l ~ K O}(n=3)$ littermates fed a HFD for two weeks. ${ }^{*} p<0.05$. Error bars represent \pm SEM. ${ }^{*} p<0.05$. 
what is known to occur in adipose tissue of HFD mice. In addition, tissue-specific insulin signaling studies revealed better insulin sensitivity in omental adipose tissue of Id3 ${ }^{\mathrm{Bcell}} \mathrm{KO}$ mice fed a HFD (Figure 14B). These results demonstrate reduced inflammation and improved insulin sensitivity in adipose tissue in a mouse model with locally elevated B-1b B cells and natural IgM production. Together, this raises the hypothesis that increasing B-1b B cell number may attenuate the metabolic consequences of obesity.

\section{B-1b B cells lacking Id3 attenuates diet-induced glucose intolerance, while $B-1 b$ B cells unable to secrete IgM have no effect.}

Together, findings in the Id $3^{B c e l l ~ K O}$ mouse suggest that improved $B-1 b$ B cell survival leads to increased local IgM production that may protect against downstream metabolic dysfunction. To test this, FACS-sorted B-1b B cells from WT, Id3 $3^{\mathrm{Bcell}} \mathrm{KO}$, or $\operatorname{slg} \mathrm{M}^{-/}$donors were adoptively transferred into Rag $1 \%$ hosts, and the mice were fed a HFD for 12 weeks (Figure 15A). While B cells from $\operatorname{slg}^{-1-}$ mice express surface $\lg M$ and secrete $\lg G$, they cannot secrete $\lg M^{175}$. Interestingly, while no body weight differences were observed after 12 weeks of HFD (Figure 15B), hosts that received Id $3^{\text {Bcell KO }} \mathrm{B}-1 \mathrm{~b}$ B cells had improved glucose tolerance compared to vehicle controls, and hosts treated with WT cells showed a trend toward improved glucose clearance (Figure 15C). No differences were seen between $\mathrm{slgM}^{-1}$ hosts and vehicle controls (Figure 15C). These results suggest a role for $\mathrm{B}-1 \mathrm{~b}$ B cells in attenuating the metabolic consequences of obesity that is 
A

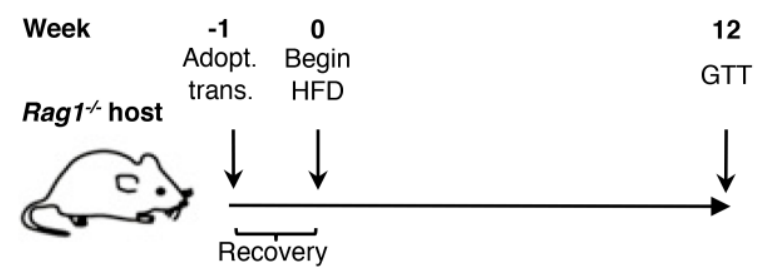

Vehicle

80k WT B-1b

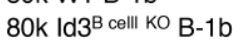

$80 \mathrm{k} \mathrm{slgM}^{-1-} \mathrm{B}-1 \mathrm{~b}$

B
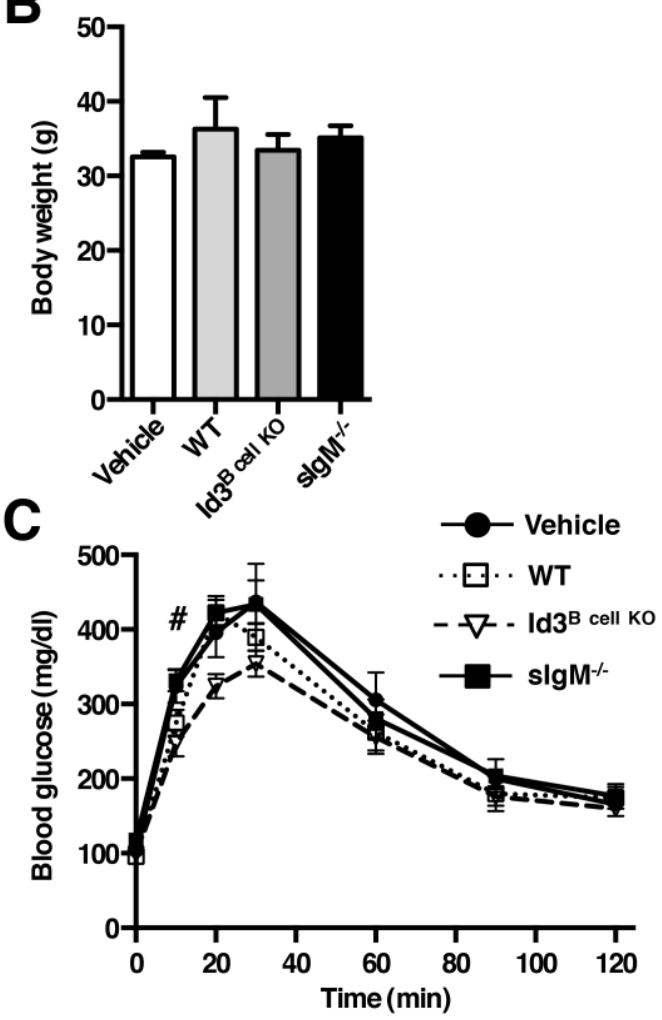
Figure 15. B-1b B cells lacking Id 3 attenuate diet-induced glucose intolerance, while B-1b B cells unable to secrete IgM have no effect. (A) Rag 1 1/ mice received either an i.p. vehicle $(\mathrm{V}, \mathrm{n}=5)$ saline injection or adoptive transfer of $8.0 \times 10^{4} B-1 b$ B cells from WT $(n=4)$, Id3 $3^{B}$ cell KO $(n=5)$, or $\operatorname{slgM}^{-/}(n=3)$ donors. After a recovery week, hosts were placed on a HFD for 12 weeks. (B) Body weight of Rag1/- hosts after 12 week of HFD. (C) GTT on Rag1/- hosts. $\# p<0.05 \mathrm{ld} 3^{\mathrm{B} \text { cell } \mathrm{KO}}$ vs $\mathrm{V}$. 
enhanced in the absence of $I d 3$ and is dependent on the ability to secrete $\lg M$ antibodies. 


\section{Discussion}

Recent studies implicate B cells in the metabolic perturbations associated with $\mathrm{DIO}^{76,78,80,81}$. As the helix-loop-helix factor Id3 has emerged as an important factor in regulating obesity development ${ }^{164}$ and $B$ cell function ${ }^{158,162,163}$, we used the Id $3^{\mathrm{Bcell}} \mathrm{KO}$ mouse to test the role of $I d 3$ and B cells in HFD-induced obesity. B cell-specific deletion of Id 3 led to improved glucose handling and a specific increase in B-1b B cells and natural IgM production within omental adipose tissue. Interestingly, loss of $I d 3$ in B cells also blunted HFD-induced inflammation and insulin resistance in omental fat, suggesting a protective role for B1-b B cells in DIO. Indeed, adoptive transfer of B-1b B cells from Id3 ${ }^{\mathrm{Bcell}} \mathrm{KO}$ mice led to improved glucose clearance in DIO Rag1\% mice, while transfer of slg $^{-/-} \mathrm{B}-1 \mathrm{~b} \mathrm{~B}$ cells did not. Together, our results provide evidence for a novel IgM-dependent role of B-1b B cells in attenuating HFD-induced metabolic dysfunction.

There are several ways by which IgM antibodies may regulate processes affected by obesity. Natural IgM antibodies produced by B-1 cells bind apoptotic cells $^{183}$, facilitating their clearance and promoting tissue homeostasis ${ }^{121}$. Indeed, infusion of T15-lgM rescued impaired apoptotic cell clearance in $s \lg M^{-1-123}$ and $\mu \mathrm{MT}^{119}$ mice. Uncleared dead cell accumulation in obese adipose tissue contributes to tissue inflammation ${ }^{190,191}$, and B-1-derived IgM reduces inflammation in vivo ${ }^{119,130}$. IgM can also regulate metabolism independent of antigen recognition. Adipocytes treated with polyclonal IgM demonstrated significantly elevated lipogenesis, glucose oxidation, and glucose uptake ${ }^{192,} 193$. These effects were similar to those observed after insulin stimulation and were 
Fc-dependent. Thus, identification of this novel mechanism leading to increased local IgM production in adipose tissue may serve to limit inflammation and the metabolic consequences of obesity. Indeed, we found reduced inflammatory

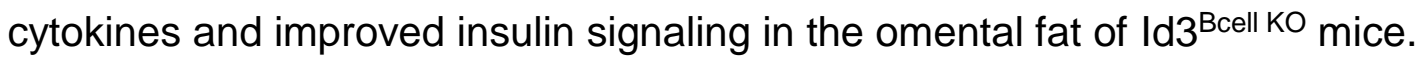

Results presented here provide evidence that loss of $I d 3$ in B cells increased B-1b B cell number and enhanced their regulatory role in HFD-induced obesity. Reduced Annexin V staining on $\mathrm{B}-1 \mathrm{~b}$ B cells in Id $3^{\mathrm{Bcell}} \mathrm{KO}$ mice suggests that $I d 3$ is a key regulator of $\mathrm{B}-1 \mathrm{~b}$ B cell survival. While $I d 3$ is known to promote apoptosis in developing bone marrow B cell progenitors through caspase-2 ${ }^{156}$, further studies are needed to identify whether $I d 3$ regulates similar pathways in B-1b B cells. Interestingly, Id3-dependent regulation of B-1b B cells cell number appears to impact B-1b-mediation of HFD-induced glucose intolerance. Despite transfer of an equal numbers of cells, there were significantly more B-1b B cells in omental fat and a greater improvement in glucose tolerance if the transferred cells lacked Id3. These findings are consistent with previous immunization studies ${ }^{184}$ showing that enhanced B-1 B cell antibody response attenuated the detrimental effects of diet-induced inflammation. Additional studies are needed to evaluate whether further boosting of B-1b B cell numbers in vivo can enhance their regulatory function in obesity-associated metabolic disease.

Results of the present study also highlight the importance of studying omental fat. The omentum is a unique fatty tissue that connects the spleen, pancreas, stomach, and colon, and plays an important role in peritoneal immunity ${ }^{194}$. In humans, omental fat comprises a major portion of VAT that has 
high metabolic activity and where inflammation correlates with insulin resistance ${ }^{135,195}$. In contrast to epididymal fat, inflammatory lipids and cytokines from omental adipose tissue drain portally into the liver where they can impair hepatic insulin sensitivity ${ }^{138,196}$. Within omental fat, organized clusters of mostly B-1 B cells and macrophages ${ }^{82,141}$ called milky spots reside in close proximity to adipocytes. Mice lacking milky spots have severely reduced T15-IgM titers ${ }^{82,179}$, suggesting that omental fat supports local antibody production. Our findings are the first to demonstrate active production of natural IgM antibodies in murine omental adipose tissue. Furthermore, we demonstrated that mice with increased omental B-1b B cell numbers and elevated IgM production displayed attenuated HFD-induced inflammation and better insulin signaling within omental fat than WT controls, suggesting that this depot may be key to understanding how B cells may regulate metabolic function. Moreover, due to the known structural similarities of omental fat across species ${ }^{139}$, results obtained from studies of murine omental fat may have important relevance to human disease. 


\section{CHAPTER 4:}

Adipose tissue B cells and IgM antibodies in an obese human cohort 


\section{Introduction}

The use of murine models has been instrumental in developing treatments for many human diseases. However, despite possessing structurally similar immune systems, mouse and human B cells display differences in surface markers, response to cytokines, and intracellular signaling ${ }^{197-199}$. These factors, along with relative inaccessibility of most lymphoid tissues, have made identifying a human B-1 B cell equivalent difficult. However, the well-documented presence of human natural $\lg \mathrm{M}$ antibodies ${ }^{107-110}$ suggests that a $\mathrm{B}$ cell with functional capabilities similar to murine B-1 B cells exists in humans.

Recently, Rothstein and colleagues identified a subset of circulating B cells in humans shown to share several unique properties of murine B-1 B cells ${ }^{90}$. This $\mathrm{B}$ cell population possessed a CD20 ${ }^{+} \mathrm{CD} 27^{+} \mathrm{CD} 43^{+}$surface phenotype and, in contrast to $\mathrm{CD} 20^{+} \mathrm{CD} 27^{-} \mathrm{CD} 43^{-}$or $\mathrm{CD} 20^{+} \mathrm{CD} 27^{+} \mathrm{CD} 43^{-} \mathrm{B}$ cells, spontaneously secreted IgM antibodies. Additional studies on sorted $C D 20^{+} C D 27^{+} C D 43^{+} B$ cells revealed other $\mathrm{B}$-1-like properties including antigen-independent $\mathrm{T}$ cell stimulation and tonic intracellular signaling. Furthermore, a fraction of this population was able to bind PC, suggesting the ability to produce antibodies that recognize the same epitope as the $\mathrm{T} 15$ family. Importantly, $\mathrm{CD} 20^{+} \mathrm{CD} 27^{+} \mathrm{CD} 43^{+}$ B cells were enriched in umbilical cord blood, suggesting functional capabilities well before the development of humoral memory. Despite these findings, it remains unknown whether, like murine B-1 B cells, this population is enriched in human omental adipose tissue or if natural antibody levels are associated with the number of these B cells. 
Similar to mice, natural IgM antibodies in humans are associated with reduced indices of cardiovascular and inflammatory disease $200-204$. In addition to IgM antibodies specific for PC (PC-IgM), IgM to malondialdehyde-low density lipoprotein (MDA)-LDL and IgM-apoB immune-complexes (IgM-IC) are associated with reduced inflammation and decreased risk of death, myocardial infarction, and stroke in prospectively followed subjects from the general community ${ }^{178,205}$. Thus, although PC-IgM has been the most extensively studied, it represents only one of several IgM antibodies known to be inversely associated with human disease ${ }^{206-208}$. Despite this, to our knowledge, our study is the first to evaluate whether natural IgM antibodies associate with inflammation or insulin resistance in an obese human population.

Several methods are generally used to assess metabolic function and insulin sensitivity in humans. The homeostatic model assessment of insulin resistance (HOMA-IR) uses equations derived from physiological studies to estimate glucose regulation and beta cell function based on fasting insulin and glucose levels ${ }^{209}$. However, this measurement relies on a data taken from a snapshot in time, and acute changes to insulin or glucose levels may skew the results. In addition, this model does not take into account factors such as circulating lipoproteins and triglycerides that are known to be associated with insulin resistance. Recently, a method that evaluates circulating lipoproteins through nuclear magnetic resonance (NMR) was shown to be highly correlated with insulin resistance and was predictive of diabetes development. Because NMR has the capacity to measure both size and particle concentration of low- 
density lipoprotein (LDL), very low-density lipoprotein (VLDL), and high-density lipoprotein (HDL), lipoprotein insulin resistance (LP-IR) analysis accounts for parameters missed by normal lipid panels that only measure particle concentration. Indeed, this method is highly predictive of progressive insulin resistance after multivariate analysis ${ }^{210-213}$ Furthermore, as LP-IR measurements are reflective of long-term metabolic function, they better reflect overall metabolic health as they are not altered by the acute environmental factors that regulate blood glucose and insulin levels.

In this study, we analyzed blood and adipose tissue from patients undergoing bariatric surgery at the University of Virginia for B cell subsets and natural IgM antibodies. While all patients were enrolled under the same criteria, individuals were recruited into our studies at two distinct time frames and different endpoints were measured. As such, they are divided into cohort 1 and cohort 2 and analyzed separately (see materials and methods). Blood, SC adipose tissue, and omental adipose tissue samples from cohort 1 were analyzed for $\mathrm{CD} 20^{+} \mathrm{CD} 27^{+} \mathrm{CD} 43^{+} \mathrm{B}$ cells via flow cytometry. Samples from cohort 2 were used for protein quantitation and LP-IR analysis. Results show for the first time that $\mathrm{CD} 20^{+} \mathrm{CD} 27^{+} \mathrm{CD} 43^{+} \mathrm{B}$ cell reside within human omental adipose tissue and correlate with circulating PC-IgM antibodies. Additional findings provide evidence that PC-IgM antibody levels within omental adipose tissue correlate strongly with circulating PC-IgM. Moreover, analysis of circulating natural IgM antibodies revealed inverse associations with inflammation and insulin resistance. Together, these findings identify additional similarities between 
murine $\mathrm{B}-1 \mathrm{~B}$ cells and human $\mathrm{CD} 20^{+} \mathrm{CD} 27^{+} \mathrm{CD} 43^{+} \mathrm{B}$ cells, and suggest that elevated levels of natural IgM antibodies may predict an improved metabolic phenotype in obese humans. 


\section{Results}

\section{$C D 20^{+} C D 27^{+} C D 43^{+} B$ cells are present in human omental adipose tissue} and correlate with circulating PC-IgM levels.

Recently, Griffin et al. identified a subset of circulating B cells $\left(\mathrm{CD} 2 \mathrm{O}^{+} \mathrm{CD} 27^{+} \mathrm{CD} 43^{+}\right)$in humans that shared several unique properties of murine B-1 B cells ${ }^{90}$. Murine B-1 B cells are found in marked abundance within omental adipose tissue relative to other adipose depots. To determine whether the same may be true for the putative human equivalent of murine B-1 B cells, we performed flow cytometry on omental fat in an obese cohort of patients undergoing bariatric surgery (cohort 1). We observed a marked enrichment of CD20 ${ }^{+} \mathrm{CD} 27^{+}{ }^{+}$D $433^{+} \mathrm{B}$ cells in the omental adipose depot compared to subcutaneous fat or blood in four of 16 patients analyzed. Figure $16 \mathrm{~A}$ is a representative flow cytometry plot of the patients whose samples displayed marked enrichment. Interestingly, patients with a higher fraction of omental adipose tissue $B$ cells that were $C D 20{ }^{+} \mathrm{CD} 27^{+} \mathrm{CD} 43^{+}$also had elevated serum PC-binding IgM (Figure 16B). While some debate remains over the exact nature of $\mathrm{CD} 20^{+} \mathrm{CD} 27^{+} \mathrm{CD} 43^{+} \mathrm{B}$ cells ${ }^{214-216}$, our novel results provide additional evidence supporting $\mathrm{CD} 2 \mathrm{O}^{+} \mathrm{CD} 27^{+} \mathrm{CD} 43^{+} \mathrm{B}$ cells as the human equivalent of murine $\mathrm{B}-1 \mathrm{~B}$ cells. Moreover, consistent with our murine findings, the number of CD20 ${ }^{+} \mathrm{CD} 27^{+} \mathrm{CD} 43^{+} \mathrm{B}$ cells correlates with increased circulating PC-IgM antibodies. 
A
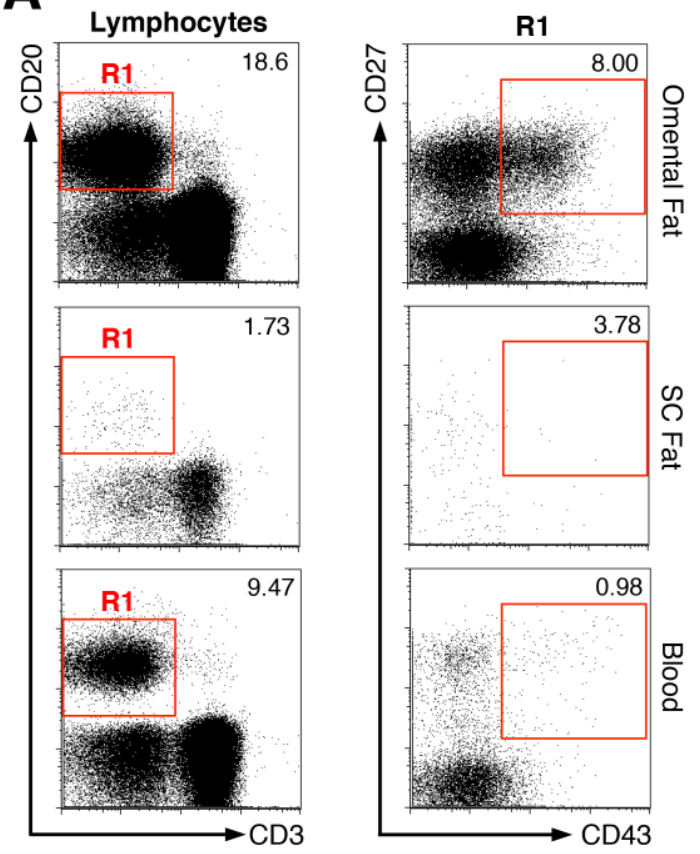

B

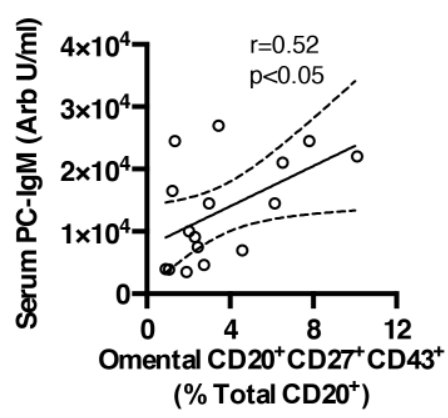


Figure 16. $C D 20+C D 27+C D 43+B$ cells in human omental adipose tissue correlate with serum PC-IgM levels. (A) Flow cytometry on omental fat, subcutaneous (SC) fat, and blood from a single patient. (B) Fraction of omental CD20 ${ }^{+} \mathrm{CD} 27^{+} \mathrm{CD} 43^{+} \mathrm{B}$ cells plotted against serum $\mathrm{PC}$-IgM levels in patients from cohort $1(n=16)$. Solid line represents Spearman correlation and dashed lines represent $95 \%$ confidence intervals. 


\section{PC-IgM antibodies in omental adipose tissue correlate with circulating PC-} IgM.

In chapter 3 , it was shown that PC-recognizing IgM antibodies can be produced locally within omental fat in mice. In a separate cohort of bariatric surgery patients (cohort 2, Table 2), PC-IgM in omental adipose tissue lysates was measured. Results demonstrated a strong positive correlation between PCIgM in omental adipose tissue and circulating PC-IgM (Figure 17). These findings are consistent with the identification of a B-1-like B cell in omental fat, and suggest the hypothesis that omental adipose tissue may also be a site of natural IgM production in humans. Furthermore, as circulating biomarkers do not always reflect levels within tissue, our findings give credence to the potential use of circulating PC-IgM as a predictor of omental adipose tissue PC-IgM levels.

\section{PC-IgM antibodies in circulation and within omental adipose tissue negatively correlate with MCP-1 levels and age.}

PC-recognizing IgM antibodies have anti-inflammatory characteristics, and chapter 3 described attenuated HFD-induced inflammation in mice with elevated T15-IgM production in omental fat. Furthermore, B-1 cells decrease in older mice ${ }^{217}$ and humans ${ }^{90}$, suggesting that their protective effects may decline with age. We examined serum for the inflammatory cytokines IFNy, TNFa, and MCP1 in cohort 2. IFNy and TNFa levels were below the level of detection in our assay (data not shown). However, MCP-1 - a macrophage chemoattractant 
Table 2. Cohort 2 baseline characteristics

\begin{tabular}{ll}
\hline Patients & 122 \\
Male & $29(24 \%)$ \\
Female & $93(76 \%)$ \\
$\begin{array}{l}\text { Metabolic HealthA,B } \\
\text { Diabetic }\end{array}$ & $50(43 \%)$ \\
$\quad$ Non-diabetic, with & $47(41 \%)$ \\
$\quad$ metabolic syndrome & \\
$\quad$ Non-diabetic & $19(16 \%)$ \\
Age & $44 \pm 10$ \\
Creatinine $(\mathrm{mg} / \mathrm{dl})$ & $0.9(0.8,1.0)$ \\
HDL $(\mathrm{mg} / \mathrm{dl})$ & $38(33,45)$ \\
Triglycerides $(\mathrm{mg} / \mathrm{dl})$ & $125(100,174)$ \\
LPIRC & \\
Large VLDL-P $(\mathrm{nmol} / \mathrm{L})$ & $5.8(3.1,11.3)$ \\
Small LDL-P $(\mathrm{nmol} / \mathrm{L})$ & $786 \pm 281$ \\
Large HDL-P $(\mu \mathrm{mol} / \mathrm{L})$ & $3.1(2.1,4.6)$ \\
VLDL size $(\mathrm{nm})$ & $55 \pm 8.4$ \\
LDL size $(\mathrm{nm})$ & $20.3 \pm 0.5$ \\
HDL size $(\mathrm{nm})$ & $8.9(8.7,9.2)$ \\
\hline
\end{tabular}

Values presented as mean \pm standard deviation or as median (interquartile range) depending on data distribution

${ }^{A}$ Metabolic syndrome defined as any three of the following: large waist circumference (men: >40in; women: $>35 \mathrm{in}$ ), hypertension, low HDL (men: $<40 \mathrm{mg} / \mathrm{dl}$; women: $<50 \mathrm{mg} / \mathrm{dl}$ ), high triglcyerides ( $>150 \mathrm{mg} / \mathrm{dl}$ ), high blood glucose $(>100 \mathrm{mg} / \mathrm{dl})$

BMetabolic health information not available for six patients

CLPIR = Lipoprotein measurement of insulin resistance 


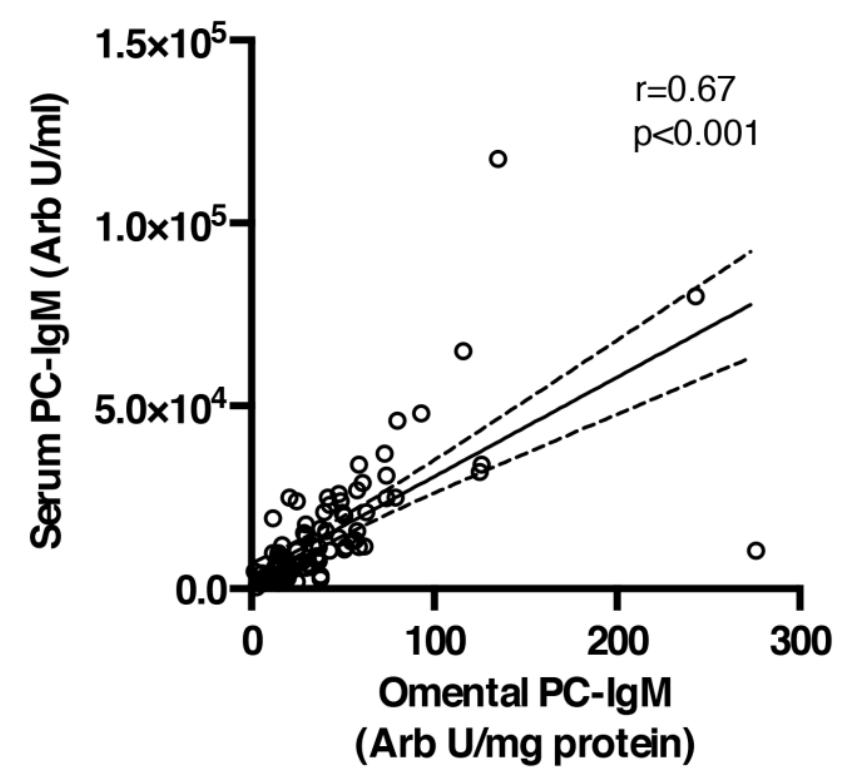


Figure 17. Human omental adipose tissue PC-IgM correlates with serum PC-IgM levels. Omental PC-IgM levels plotted against serum PC-IgM levels in patients from cohort 2 (see table 2). Solid line represents Spearman correlation and dashed lines represent $95 \%$ confidence intervals. 
protein known to be highly predictive of insulin resistance 218,219 - could be clearly measured and consistent with an anti-inflammatory role for PC-IgM, we found that circulating levels of MCP-1 had inverse correlations with PC-IgM in both the circulation and within omental adipose tissue (Table 3). Interestingly, both circulating and omental PC-IgM were also inversely associated with age (Table 3). Consistent with murine results, our studies provide evidence that PC-IgM antibodies are present in human omental adipose tissue, associate with reduced inflammation, and decline with age.

IgM antibodies against PC and MDA-LDL, along with IgM-apoB immune complexes, are associated with lower indices of inflammatory disease. To determine if these human IgM antibodies and immune complexes were associated with insulin resistance, each patient in cohort 2 was given a score from 0 (most insulin sensitive) to 100 (most insulin resistant) based on NMR-lipid analysis. While we found no correlation with LP-IR scores and circulating PC-IgM (data not shown), LP-IR was negatively associated with IgM-IC and displayed a trending inverse correlation with IgM antibodies to MDA-LDL (Table 4). Both IgMIC and IgM MDA-LDL were positively associated with HDL. No correlations were observed between either insulin sensitivity or HDL and IgG-IC or IgG MDA-LDL (Table 4). Together, our results suggest that multiple natural IgM antibodies are associated with protective phenotypes in an obese human population. 
Table 3. PC-IgM negatively correlates with serum MCP-1 and age.

\begin{tabular}{lllll}
\hline Measurement & \multicolumn{2}{c}{ MCP-1 (serum) } & \multicolumn{2}{c}{ Age } \\
\hline & Spearman $r$ & $p$-value & Spearman $r$ & $p$-value \\
\hline PC-lgM & & & & \\
Serum & -0.19 & $\mathbf{0 . 0 5}$ & -0.25 & $\mathbf{0 . 0 0 7}$ \\
Omental fat & -0.21 & $\mathbf{0 . 0 2}$ & -0.23 & $\mathbf{0 . 0 1}$ \\
\hline
\end{tabular}

Table 4. IgM autoantibodies and apoB-immune complexes correlate with HDL levels and improved LP-IR scores.

\begin{tabular}{lllll}
\hline Measurement & \multicolumn{2}{c}{ LP-IR } & \multicolumn{2}{c}{ HDL } \\
\hline & $\begin{array}{l}\text { Spearman } \\
\text { coefficient }\end{array}$ & p-value & $\begin{array}{l}\text { Spearman } \\
\text { coefficient }\end{array}$ & p-value \\
\hline & & & & \\
IgM-IC & -0.24 & $\mathbf{0 . 0 1}$ & 0.32 & $\mathbf{0 . 0 0 0 5}$ \\
IgG-IC & -0.002 & 0.98 & 0.08 & 0.35 \\
IgM MDA-LDL & -0.15 & 0.12 & 0.19 & $\mathbf{0 . 0 4}$ \\
IgG MDA-LDL & -0.08 & 0.38 & 0.02 & 0.85 \\
\hline
\end{tabular}




\section{Discussion}

Much of the knowledge about immune regulation of disease has come from murine studies, and in many cases, the relevance to human disease is unclear. While immunohistochemical analysis has demonstrated B cells within human omental fat ${ }^{76,141}$, the lack of a known human B-1 cell equivalent had made subset analysis difficult. However, the well-known existence of natural antibodies in humans suggests the presence of a B-1 cell. Recently, a circulating human $\mathrm{CD} 2 \mathrm{O}^{+} \mathrm{CD} 27^{+} \mathrm{CD} 43^{+} \mathrm{B}$ cell with several characteristics similar to murine B-1 B cells, such as the ability to spontaneously secrete IgM and bind PC antigen, was identified ${ }^{90}$. Here, we show for the first time that, like murine B-1 B cells, CD20 ${ }^{+} \mathrm{CD} 27^{+} \mathrm{CD} 43^{+} \mathrm{B}$ cells are enriched in human omental adipose tissue compared to subcutaneous adipose tissue and blood. While not all omental adipose tissue samples displayed high numbers of these cells, the variability in omental $\mathrm{CD} 20^{+} \mathrm{CD} 27^{+} \mathrm{CD} 43^{+} \mathrm{B}$ cells may be due to uneven clustering and distribution of milky spots within individual depots, variable sampling at the time of surgery, or a reflection of differences in individual patients. Despite the variability, we showed the presence of omental $C D 20+C D 27+C D 43^{+} B$ cells correlated with circulating PC-IgM levels. Our findings add to the known similarities between murine B-1 B cells and human $\mathrm{CD} 20^{+} \mathrm{CD} 27^{+} \mathrm{CD} 43^{+} \mathrm{B}$ cells, and indicate that further analysis of omental adipose tissue may improve our understanding of the role B-1 B cells play in metabolic regulation.

Additional studies revealed that IgM autoantibodies and immune complexes were associated with decreased MCP-1 levels, increased HDL, and 
improved LP-IR score in a cohort of obese individuals. Natural IgM antibodies

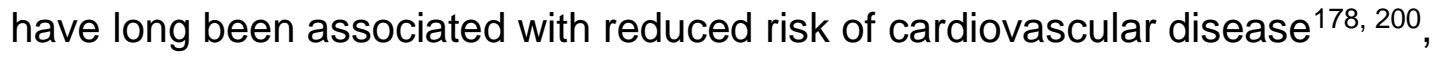
and our findings suggest they may also be important biomarkers of metabolic function. Interestingly, neither of the IgG antibodies we analyzed had any association with inflammation or LP-IR, supporting the hypothesis that protection is specific to IgM. Our mixed associations with a variety of $\lg M$ antibodies suggest that protection may stem from overall increased natural IgM production, and additional studies are needed to identify whether additional IgM antibodies associate with insulin sensitivity. Further understanding of B-1 B cells and natural IgM antibodies in murine and human adipose tissue may lead to novel biomarkers and new strategies to limit inflammation and the metabolic consequences of obesity. 
CHAPTER 5:

Summary, General Discussion, and Future Directions 


\section{Summary}

In chapter 3 , a mouse containing a B cell-specific deletion of the HLH factor Id3 was used as a tool to examine a potential role for B cells in the context of HFD-induced obesity. When challenged with a HFD for 12 weeks, these mice displayed a modest but significant improvement in glucose tolerance compared to HFD-fed littermate controls. While Id3 has reported roles as a regulator of B-2 B cell function, adoptive transfer studies suggested that loss of $I d 3$ function in a B-2 B cell could not account for the metabolic phenotype observed in the Id $3^{B}$ cell $\mathrm{KO}$ mouse. Further analysis provide the first evidence that loss of $I d 3$ in B cells leads to a specific increase in B-1b B cell number and natural IgM production in adipose tissue. Follow-on studies demonstrated that $I d 3$ likely functions to negatively regulate $B-1 b$ B cell survival. Interestingly, increased B-1b B cell number and IgM production correlated with blunted HFD-induced inflammation and improved insulin signaling in omental adipose tissue. Moreover, adoptive transfer of B-1b B cells lacking $l d 3$ was able to attenuate HFD-induced glucose intolerance in Rag 1\% mice. As transfer of $\operatorname{slg}^{-1-B}$ B-1b B cells had no effect, results suggest that $B-1 b$ B cells may play a protective role in mediating metabolic dysfunction associated with obesity through production of $\lg \mathrm{M}$ antibodies.

In chapter 4 , studies using human tissue were performed to test the hypothesis that B-1 B cells and natural antibodies are present in human omental adipose tissue. Similar to findings in mice, we identified a human B cell known to have B-1-like qualities in omental adipose tissue of patients undergoing bariatric 
surgery. The frequency of these B cells in omental fat correlated with circulating levels of PC-IgM antibodies, providing further support that these cells are the human equivalent of murine B-1 B cells. Additional studies showed that various natural IgM antibodies and immune complexes negatively correlated with systemic inflammation and insulin resistance, suggesting that elevated production of lgM antibody may be associated with improved metabolic function. Together, studies performed in mice and humans provide the first evidence that B-1 B cell-derived natural IgM antibodies may play important roles in regulating inflammatory and metabolic dysfunction associated with obesity. Future studies are needed to further evaluate B-1 B cell function in adipose tissue, to determine the potential protective mechanism(s) of IgM in the context of obesity, and to test whether enhancing B-1 B cell production of natural IgM antibodies may have therapeutic potential for attenuating obesity-induced metabolic disease. 


\section{General discussion and future directions}

\section{B cells likely regulate obesity and metabolism in a subset-dependent} manner.

Over the last decade, it has become evident that crosstalk exists between metabolic tissues and members of the innate and adaptive immune systems. Recently, B cells have been identified as important players in the emerging field of immuno-metabolism. B cells can be divided into two major subsets with differing roles in the immune system. B-2 B cells respond to T-dependent antigens, undergo class switching and somatic hypermutation, and produce highaffinity antibodies that are crucial components of the adaptive immune system ${ }^{83}$. On the other hand, B-1 B cells produce evolutionarily-conserved natural antibodies, either spontaneously or rapidly after activation, that contribute to initial defense against infection and contribute to tissue homeostasis ${ }^{96}$. Insight into how $B$ cells function in the context of other inflammatory diseases such as atherosclerosis have provided strong evidence that B-1 and B-2 B cells may have differing - and sometimes opposing - roles in disease ${ }^{220}$. Recent studies identifying a pathogenic role for B-2 B cells in obesity-related insulin resistance, combined with results from our studies that suggest B-1b B cells may attenuate metabolic dysfunction in obesity, indicate that differing B cell subsets likely have opposing impacts on adipose tissue function and metabolic health as well.

While B cells had previously been identified in VAT76-78, 82, 179, a highimpact study by Winer and colleagues in 2011 was the first to identify B-2 B cells as promoters of HFD-induced insulin resistance ${ }^{81}$. In this report, the authors 
found that DIO led to a systemic adaptive antibody response highlighted by increased circulating IgG antibodies, along with elevated spontaneous IgG secretion and reduced IgM production by splenocytes. Preliminary studies in our laboratory support the notion that HFD promotes T-dependent antibody responses, as a trend for more germinal center B cells are found in the spleens of DIO mice (Figure 18). Further analysis by Winer and colleagues revealed an accumulation of class-switched lgG + B-2 B cells and an abundance of proinflammatory IgG2c antibodies within VAT, indicating that DIO may also induce a local adaptive immune response within fat. Adoptive transfer studies showed that B-2 B cells were able to drive glucose intolerance and insulin resistance in B celldeficient $\mu \mathrm{MT}$ mice. Our studies corroborate these findings, as we obtained similar impairment of glucose tolerance after injecting WT B-2 B cells into $\mu \mathrm{MT}$ mice. Interestingly, Winer et al. found this effect was blunted when donor B-2 B cells lacked functional major histocompatibility complex (MHC) I or II, suggesting that antigen presentation to T cells is required for B-2 B cells to negatively impact metabolic function. Additional studies showed that transfer of IgG purified from obese donors into $\mu \mathrm{MT}$ hosts was sufficient to impair glucose homeostasis. As IgG from chow-fed donors and IgM from DIO mice had no impact, these findings provide evidence that DIO induces a pathogenic T-dependent B-2 IgG antibody response that impairs systemic metabolic function. 
A

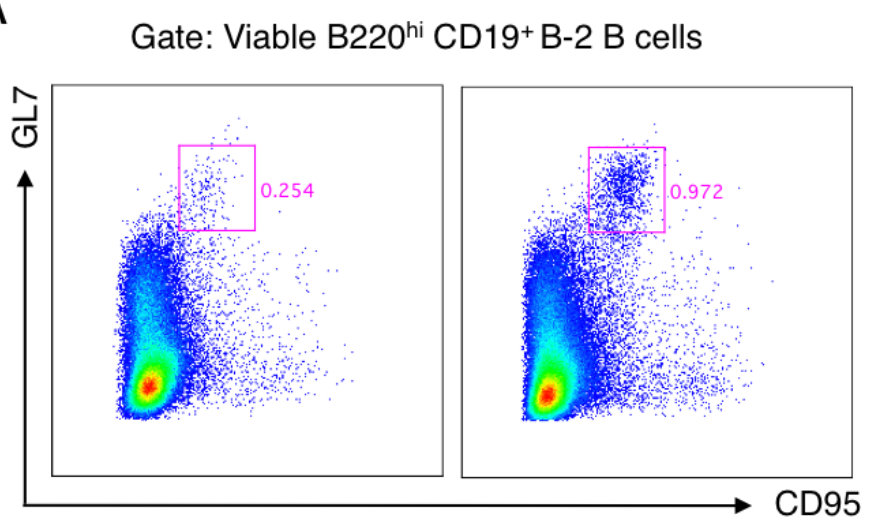

B

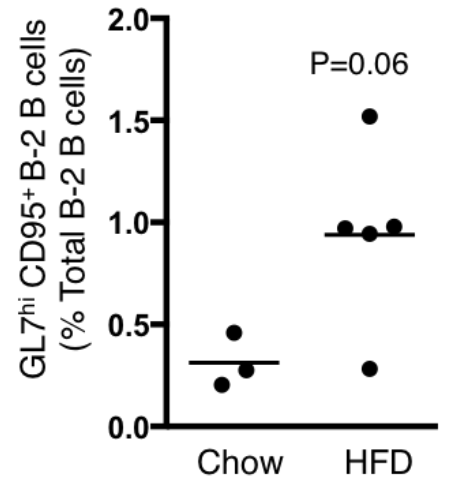


Figure 18. HFD may lead to splenic germinal center formation. C57BI/6J mice were fed chow $(n=3)$ or a HFD $(n=5)$ for 12 weeks. (A) Flow cytometry staining for splenic $\mathrm{B} 22 \mathrm{H}^{\mathrm{Hi}} \mathrm{CD} 19^{+} \mathrm{GL} 7{ }^{\mathrm{Hi}} \mathrm{CD} 95^{+}$germinal center $\mathrm{B}$ cells. (B) Quantitation of germinal center $B$ cells. Each dot represents a single mouse. 
Identification of class-switched B-2 B cells and IgG2C antibodies in VAT, along with previous reports of VAT-resident $\mathrm{T}$ cells containing a restricted $\mathrm{T}$ cell receptor (TCR) repertoire ${ }^{81,221}$ suggest a local immune response. Recently, adipose tissue macrophages were shown to induce $\mathrm{T}$ cell proliferation and $\mathrm{TH}_{\mathrm{H}} 1$ polarization through MHC II antigen presentation ${ }^{222}$. A significant fraction of macrophages expressing MHC II were found near proliferating T cells in FALCs, suggesting that these regions may be important for antigen-driven immune responses in fat. Interestingly, obesity progression led to a redistribution of macrophage-T cell interactions toward CLS, which are regions of high inflammatory output surrounding uncleared dead adipocytes ${ }^{190,191}$. It is possible that apoptotic adipocytes are a source of autoantigen that helps drive the inflammatory IgG response seen in obesity. In support of this, IgG autoantibodies against phosphogluconate dehydrogenase - a highly expressed protein in adipocytes - were found in roughly $40 \%$ of overweight insulin-resistant patients ${ }^{81}$. More studies are needed to address the antigen specificity of B-2 B cells in adipose tissue. Identifying whether antibodies against certain antigens are driving a pathogenic response during obesity may allow for targeted immunotherapy aimed at improving metabolic function.

In chapter 3 , we show that a mouse model with specifically increased B-1b B cells and elevated IgM production in fat has an improved inflammatory and metabolic phenotype after a HFD compared to WT controls. Adoptive transfer studies showed that B-1b B cells could attenuate the development of dietinduced glucose intolerance only when able to secrete lgM. Most insight into B- 
$1 \mathrm{~b} B$ cell function stems from infection studies ${ }^{223}$, and our findings are the first to identify B-1b B cells as regulators of obesity-induced metabolic dysfunction and provide evidence that they play a contrasting role to B-2 B cells in this context. As described here in following sections, further analysis regarding $B-1 b$ B cell function in obesity and the specific role(s) IgM may play in adipose tissue biology is needed.

In addition to antibody production, cytokines derived directly from B cells may contribute to metabolic regulation. B-2 B cells have the capacity to secrete a multitude of $\mathrm{TH}_{\mathrm{H}}$ and $\mathrm{TH}_{\mathrm{H}}$ polarizing cytokines. Sorted FO B-2 B cells from obese mice secreted more IL-6 and macrophage inflammatory protein-2 (MIP-2), and less IL-10 than lean controls, suggesting a pro-inflammatory phenotype ${ }^{77}$. Similar results were found in T2D patients, where circulating $B$ cells secreted more IL-8 (an ortholog of murine MIP-2) and less IL-10 in response to toll-like receptor (TLR) stimulation than $B$ cells from healthy controls ${ }^{101}$. Very recently, a subset of IL-10-producting B cells, possessing a different surface phenotype than on previously characterized BREG B cells, was identified in adipose tissue ${ }^{102}$. Interestingly, these cells were able to spontaneously secrete IL-10 ex vivo - a feature absent in previously described BREGs that require several hours of stimulation for IL-10 production. Adipose tissue IL-10-secreting B cells decreased with progressing obesity, and B cell-specific deletion of IL-10 led to increased adipose tissue inflammation and insulin resistance. As IL-10 has known functions in suppressing activated M1 macrophages ${ }^{224}$ and can directly protect adipocytes from TNFa-induced insulin resistance ${ }^{225}$, B cell IL-10 production may be an 
important mechanism by which B cells can protect against adipose tissue dysfunction. Further analysis of this unique B cell subset is needed to fully understand their function and potential use as a therapeutic agent. Additional study is also needed to identify whether adipose tissue B cells produce cytokines that may have other immuno-regulatory or metabolic functions.

\section{$B-1 b$ B cells are poorly understood.}

Results described in chapter 3 indicate more study is needed to understand how B-1b B cells function in adipose tissue and what role they play during the progression of obesity. In order to do this, more insight into B-1b B cell biology is required. Owing mostly to the shared surface phenotype of B-1a and $\mathrm{B}-1 \mathrm{~b}$ B cells - the only known distinction is their expression of CD5 - many studies do not distinguish between the two, thus making our understanding of B1b B cells incomplete. However, despite sharing several properties such as selfrenewal and natural IgM production, evidence suggests that $B-1 \mathrm{a}$ and $\mathrm{B}-1 \mathrm{~b} B$ cells are distinct $B$ cell subsets with overlapping, but non-redundant functions ${ }^{96}$. The existence of B-1a B cells prior to birth and B-2 development is well documented ${ }^{87}$, but B-1b development is less understood. Studies have identified precursor cells that produce only B-1a B cells as early as E8.5 during development in the splanchnopleura region ${ }^{88}$. However, both B-1a and B-1b precursors are found in the fetal liver, well before B-2 B cells develop ${ }^{89}$. Additional studies in adult mice have shown that transfer of lymph node cells can reconstitute B-1b, but not B-1a, populations in Rag 1/ hosts ${ }^{226}$. Moreover, 
transfer of bone marrow preferentially generates B-1b B cells over B-1a B cells, and this skewed ratio becomes more pronounced with increasing donor age ${ }^{217}$. Elegant work from Ghosn and colleagues showed that transfer of a single LinCD34- $\mathrm{CKit}^{+} \mathrm{Sca} 1^{+} \mathrm{C} 150^{+}$hematopoietic stem cell (HSC) from an adult Kusabira Orange transgenic mouse was able to replenish splenic and peritoneal B-2 populations of lethally irradiated hosts. Interestingly, a population of B-1b B cells within the peritoneal cavity was partially restored, but no B-1a B cells were generated $^{227}$. To further complicate things, a progenitor population found in fetal liver, and to a lesser degree in bone marrow, was able to reconstitute B-1b and limited B-1a populations, but not B-2 B cells. ${ }^{228}$ These findings suggest that B-1b B cells share developmental timing with both B-1a and B-2 B cells, and at least have the potential to differentiate from overlapping progenitor populations. Presently, it is unclear if B-1b B cells generated during development differ functionally from those derived from adult precursors, and further studies are needed to delineate the developmental differences between B-1b B cells and other B cell subsets.

In addition to possessing distinct developmental patterns, B-1a and B-1b B cells appear to have different effector functions. At the onset of infection, both B-1a and B-1b B cells migrate from the peritoneal cavity to the spleen or mucosal tissues where they differentiate into antibody-secreting cells ${ }^{177,229}$. However, while only B-1a B cells localize in the respiratory tract draining lymph nodes and produce $\lg \mathrm{M}$ after influenza virus infection ${ }^{93}, \mathrm{~B}-1 \mathrm{~b}$ B cells are sufficient to protect against $B$. hermsii bacteria and appear to mount a memory response after 
immunization $^{92,230}$. Furthermore, while B-1a B cells protected against sublethal infection of $S$. pneumoniae in naïve mice, only B-1b B cells conferred immunization-dependent survival in mice treated with a lethal dose of the same bacteria ${ }^{94}$. These findings are supported by studies showing high junctional VH diversity in $\mathrm{B}-1 \mathrm{~b}$ compared to $\mathrm{B}-1 \mathrm{a} \mathrm{B}$ cells, providing evidence that $\mathrm{B}-1 \mathrm{~b}$ B cells have the ability to generate a memory-like response ${ }^{231-233}$. In addition to being critical mediators of immunity, a recent study identified a protective role intrinsic to $B-1 b$ B cells in autoimmunity ${ }^{95}$. Here, the authors found that $B-1 b$ B cells were required to produce an IgM antibody that attenuated IL-17-producing $\mathrm{TH}_{\mathrm{H}}$ cells ( $\left.T_{H} 17\right)$ activity and reduced disease progression in SLE-prone mice. Together, B$1 \mathrm{~b} B$ cells appear to be a unique bridge between the innate and adaptive immune systems and play critical roles in mediating infection and autoimmunity that are not replicated by other known B cell subsets.

\section{B-1b B cells may be an important mediator of adipose tissue and metabolic function.}

The results presented in chapter 3 indicate that $B-1 b$ B cells may play a protective role in obesity-associated metabolic disease, and additional studies are needed to identify how these cells function in adipose tissue (Figure 19). Our findings are the first to show that cells within omental fat are a source of T15-IgM natural antibodies. As increased production was observed in Id $3^{\mathrm{B}}$ cell $\mathrm{KO}$ mice that have specifically elevated B-1b B cell numbers, we hypothesize B-1b B cells are a major source of natural IgM antibodies in adipose tissue. To test whether this is 
the case in WT animals, similar T15-IgM ELISAs described in chapter 2 could be performed on culture supernatants from B-1a, B-1b, and B-2 B cells sorted from omental fat of $\mathrm{C} 57 \mathrm{BI} / 6$ mice. The main challenge to these experiments is limited cell yield - several attempts at sorting omental cells in our hands produced no more than 5,000 of any one B cell subset from a single mouse (data not shown) - suggesting that pooling mice or further optimizing cell extraction techniques will be necessary. In parallel, more sensitive ELISPOT assays that quantify antibodysecreting cells could be utilized to determine the fraction of T15-IgM-producing cells from each B cell subset in omental fat. Similar studies looking at antibody production from B cell subsets in obese adipose tissue are also needed to determine whether obesity progression results in altered local IgM production.

As our findings in humans described in chapter 4 suggest that other $\operatorname{lgM}$ antibody clones besides those that recognize PC may be associated with insulin sensitivity, full analysis of immunoglobulin repertoires of omental B-1b B cells is needed. High-throughput sequencing can identify heavy and light chain variable regions ( $V_{H}$ and $V_{L}$, respectively) that make up the antigen-binding portion of the BCR. Since this technology is generally used to determine the frequency of 


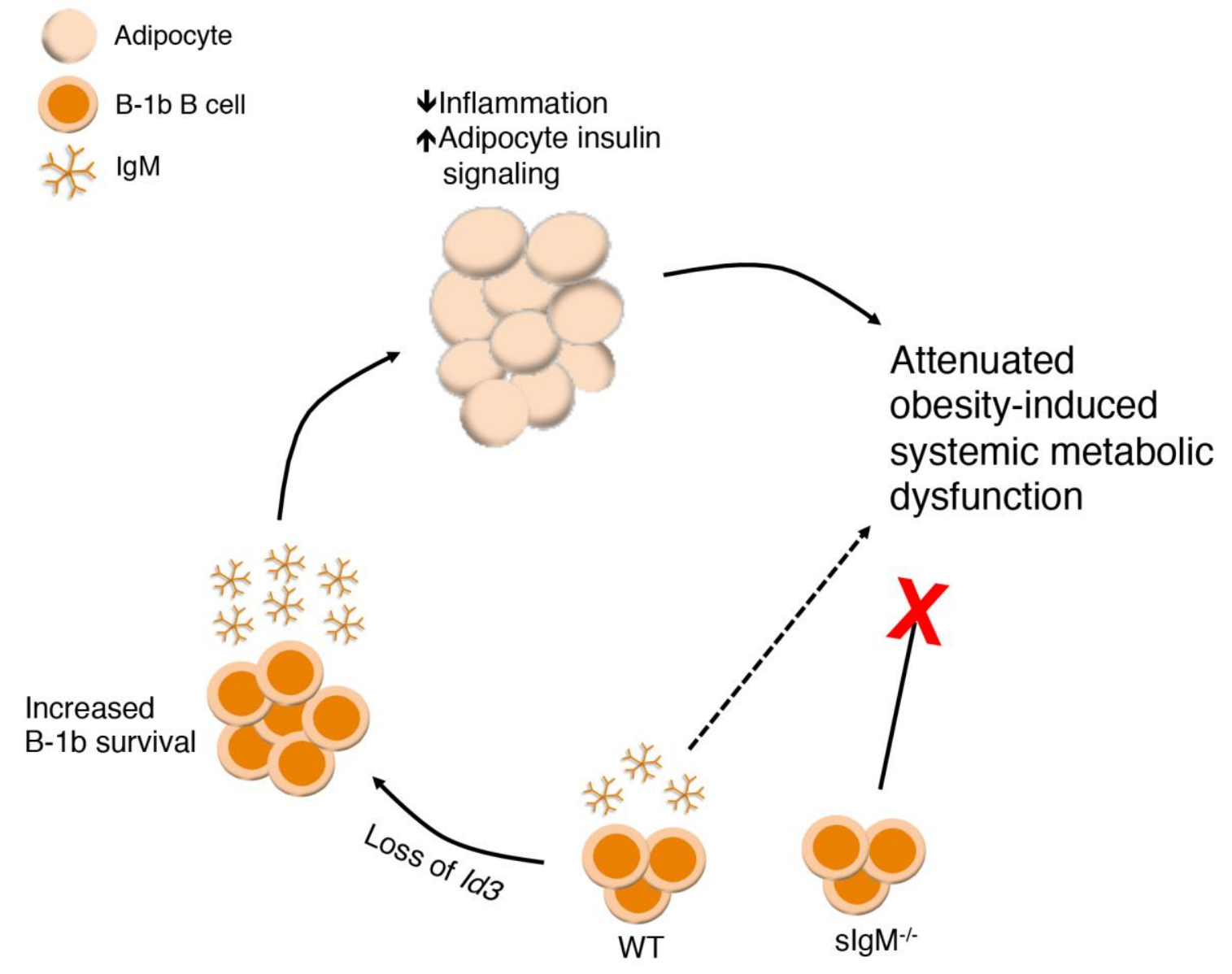


Figure 19. Model for how B-1b B cells may play a protective role in mediating obesity-induced metabolic dysfunction. In the absence of $I d 3$, B$1 \mathrm{~b} B$ cell numbers are elevated in adipose tissue. This correlates with reduced inflammation and improved insulin sensitivity in adipose tissue of mice fed a highfat diet, suggesting that boosting B-1b B cell number may improve adipose tissue function. Furthermore, B-1b B cells null for Id 3 were able to attenuate obesityinduced systemic metabolic dysfunction in Rag 1/ hosts, while WT B-1b B cells had a moderate effect. B-1b B cells from slgM ${ }^{-/-}$mice had no effect, suggesting that secreted IgM may a key regulator of metabolism. Future studies into how B$1 \mathrm{~b} B$ cells and IgM antibodies function in adipose tissue and whether increasing $B-1 b$ B cell number and antibody response via vaccination improves metabolic health are needed. 
specific $V_{H}$ and $V_{L}$ regions in pooled $B$ cell populations, antigen binding information that can be gleaned from specific $V_{H}$ and $V L$ combinations is often lost. However, recent advances in next-generation sequencing allow for the $V_{H}$ and $V_{L}$ combination of large quantities of single cells to be determined ${ }^{234}$. This approach to characterizing omental B-1b B cell antibody repertoires could provide an unbiased method for determining specific antigens that antibodies from this $B$ cell population may recognize. Studies that compare $V_{H}$ and $V_{L}$ combinations between B-1b B cells in lean and obese omental fat may help determine specific protective antibody clones that decrease with progressing obesity, and conversely, could potentially identify changes in B-1b B cell antibody repertoires that contribute to disease progression. Results from these studies could then be used to determine the therapeutic potential of targeted adipose tissue antibody delivery or neutralization on obesity-induced metabolic dysfunction.

Our results showing that adoptive transfer of B-1b B cells lacking Id 3 attenuated obesity-associated glucose intolerance in Rag $1 \%$ mice suggests that immunotherapy using these B cells could improve metabolic function. However, since recipients of WT B-1b B cells displayed a trend that approached significance for improved systemic glucose tolerance, more study is needed to determine whether this effect can also be induced by WT B-1b B cells. Despite the transfer of equivalent numbers of cells, Rag $1^{-}$hosts that received Id $3^{B}$ cell KO B-1b B cells had roughly two-fold more omental B-1b B cells three weeks posttransfer than those that received WT cells, suggesting that increased B-1b B cell 
number may lead to an improved metabolic phenotype. As our adoptive transfers consisted of a single injection of $8.0 \times 10^{4} \mathrm{~B}-1 \mathrm{~b} \mathrm{~B}$ cells, it is possible that simply increasing the number of cells transferred, or including additional booster injections, may confer a higher level of protection. Furthermore, since our studies were performed in mice lacking all B cells and T cells, studies are also needed to evaluate $B-1 b$ transfer into hosts with a more complete immune repertoire. While no complete B-1b-specific knockout model currently exists, $T L R 9^{-/-}$mice have a specific reduction in peritoneal B-1b B cells ${ }^{95}$. Obesity studies comparing these mice and those receiving WT B-1b adoptive transfers would help elucidate whether B-1b B cells have therapeutic potential in the presence of other immune cells known to play a role in mediating the effects of obesity. Due to their ability to self-maintain and self-expand, B-1b B cells have intriguing potential as an immunotherapy agent and additional studies evaluating them in this context may reveal exciting therapeutic roles for B-1b B cells in obesity and other inflammatory diseases.

Immunization is another potential method for enhancing any protective features B-1b B cells may have. B-1b B cells can produce antigen-specific antibodies to various $\mathrm{T}$-independent antigens ${ }^{223,226}$; a response that aids in the clearance of $B$. hermsii and $S$. pneumoniae ${ }^{92,94}$. Indeed, immunization of mice with heat-killed S. pneumoniae resulted in an IgM antibody response, and attenuated the development of atherosclerosis ${ }^{184}$. As this response is driven by $\mathrm{B}-1 \mathrm{~b} \mathrm{~B}$ cells ${ }^{94}$, these findings highlight the potential use of immunization to induce B-1b antibody responses that may protect against diet-induced 
inflammatory disease. Interestingly, although milky spots in omental adipose tissue lack follicular dendritic cells required for normal germinal center reactions ${ }^{82,235}$, they are able to trap bacteria and particulates suspended in the peritoneal fluid ${ }^{236-238}$ and can support a limited immune response in SLP mice lacking conventional secondary lymphoid organs ${ }^{82}$. These findings suggest that these unique clusters of B-1 B cells and macrophages may be important sites of adipose tissue antibody production. Studies are needed to analyze if immunization with S. pneumoniae leads to local B-1b antibody response in adipose tissue, and whether this can protect against glucose intolerance and insulin resistance in obesity.

\section{Id 3 is a regulator of $B-1 b B$ cells}

Id3 is a member of the HLH family of transcription factors that also includes basic-HLH (bHLH) proteins containing a basic DNA-binding domain. After bHLH members homo- or hetero-dimerize, they can bind DNA at E-box (CANNTG) motifs and directly activate or repress transcription ${ }^{144}$. Id 3 can also dimerize with bHLH proteins, but due to a lack of a DNA-binding domain, Id3 acts in a dominant-negative manner to prevent bHLH function ${ }^{146}$. Prior to our studies, no role for Id 3 in B-1b B cells had been identified, and understanding of Id3's function in B cells is limited to studies in B-2 B cells. In these cells, much of Id3's activity is thought to be through regulation of bHLH proteins E47 and E12 (two splice variants of the E2A gene) that play prominent roles in B-2 cell development and function ${ }^{153,161,239,240}$. Id 3 has been shown to regulate various 
aspects of B-2 B cell function such as proliferation after BCR crosslinking ${ }^{158}$ and class-switch recombination ${ }^{159,160}$. As both Ig class switching and clonal expansion are critical components of an antibody response, these findings may help explain the impaired T-dependent and T-independent IgG antibody responses in $I d 3^{-/}$mice ${ }^{158}$, although the contribution of loss of $I d 3$ in other cells must also be accounted for. In addition to a potential role in antibody response, Id3 over-expression induced apoptosis and growth arrest in B-2 progenitors ${ }^{155,}$ 156, and down-regulation of Id3 was required for E47-mediated B cell lineage specification ${ }^{157}$. Despite these findings, Id $3^{-/-}$mice have normal mature B-2 B cell numbers ${ }^{158,168}$, suggesting that loss of $I d 3$ has a limited impact on B-2 B cell development.

In contrast to B-2 B cells, results described in chapter 3 indicate that loss of $I d 3$ in B cells leads to a specific increase in peritoneal and adipose tissue B-1b B cells. Adoptive transfer studies indicated that this effect is, at least in part, due to loss of $I d 3$ in mature B-1b B cells. As LPS-injection studies in Id $3^{B}$ cell KO mice revealed reduced omental B-1b Annexin V staining but no differences in BrdU incorporation, we hypothesize that $I d 3$ regulates mature $\mathrm{B}-1 \mathrm{~b}$ B cell number by limiting survival. Furthermore, the trend for reduced B-1b Annexin V expression in untreated mice could explain the disparity of $B-1 b$ B cell numbers at baseline, as consistent small variations in B-1b apoptosis could lead to substantial differences in cell number over time. However, these findings do not rule out the possibility that $I d 3$ could also regulate B-1b B cell development. While understanding of B-1b B cell development is incomplete, flow cytometry analysis 
of fetal liver or bone marrow of $\mathrm{Id} 3^{\mathrm{B} \text { cell } \mathrm{KO}}$ mice could be performed to identify differences in progenitors known to be capable of producing B-1b B cells ${ }^{227,228}$. If Id3 plays a role in regulating B-1b B cell development, we might expect to see an increase in one of these populations. Two emerging technologies, including one that allows for quantitation of mRNA by flow cytometry, and mass cytometry ${ }^{241}$ that can evaluate up to 40 surface or intracellular markers at once, have the potential be instrumental in identifying gene expression and signaling patterns in minute progenitor populations. Utilization of these novel methods will allow for further evaluation of potential checkpoints that $I d 3$ and other factors may regulate during $\mathrm{B}-1 \mathrm{~b}$ development.

While B-1 B cells are able to self-maintain their population in the absence of specific stimulatory signals, the mechanisms that regulate B-1 B cell survival are unclear. Our findings suggest that $I d 3$ may be a key regulator of B-1b B cell survival, and additional study into how $I d 3$ functions in B-1b B cells may reveal important differences between these cells and other B subsets. One characteristic that distinguishes B-1 from B-2 B cells is the constitutive expression of various transcription factors in their activated form that are only found in B-2 B cells after stimulation. Two of these factors expressed in their activated, phosphorylated form in B-1 B cells, signal transducer and activator of transcription-3 (STAT3) ${ }^{242}$ and extracellular signal-regulated kinase 1/2 $(\text { ERK1/2 })^{243,244}$, are known inducers of survival ${ }^{245,246}$. As $/ d 3$ is activated by the Ras-ERK MAPK cascade in thymocytes ${ }^{247}$, it is possible that ERK $1 / 2$ signaling activates $I d 3$ to serve as a regulator against uncontrolled survival in $B-1 b$ B cells. 
In addition, E2A-mediated STAT6 activation of IgE class-switch recombination in Id2\% B cells was inhibited by Id2 overexpression ${ }^{248}$, suggesting a synergistic role for E2A in and STAT proteins. Future work is needed to determine whether E12 or E47 work with STAT3 to promote survival in B-1b B cells, and whether Id3 may serve as a negative regulator of this process. Another study demonstrated that TGF $\beta$ was able to induce apoptosis in B lymphocyte progenitor cells in a mechanism dependent on Id 3 expression ${ }^{155}$. Follow-up analysis showed that this effect was dependent on caspase 2 signaling ${ }^{156}$, and further studies are needed to test whether Id 3 regulates B-1b B cell survival in a similar manner.

In addition to targeted studies derived from known Id 3 function in other cell types, comparative microarray analysis of WT and $I d 3^{-\sim} \mathrm{B}-1 \mathrm{~b}$ B cells should also be performed. As $I d 3$ is known to function very differently depending on the cell type and available binding partners ${ }^{149,154}$, this could reveal important factors that are alternatively expressed in the absence of $I d 3$ in an unbiased manner. Furthermore, comparison array studies between WT and Id $3^{-/} \mathrm{B}-1 \mathrm{a}$ and B-1b B cells could be performed to identify factors differentially expressed only in $I d 3^{-/-B}$ $1 \mathrm{~b}$ B cells. This could identify factors crucial for distinguishing the two similar B cell subsets. Together, these studies have the potential to uncover novel pathways that are not only regulated by $I d 3$, but that may be critical for understanding the differences between $\mathrm{B}-1 \mathrm{a}$ and $\mathrm{B}-1 \mathrm{~b}$ B cells.

\section{Possible mechanisms for IgM regulation of adipose tissue biology}


The studies presented here show that when challenged with a HFD, a mouse model with elevated IgM antibodies displays reduced adipose tissue inflammation, improved adipose tissue insulin signaling, and attenuated systemic glucose intolerance. Adoptive transfer studies suggest that some of these effects may be dependent on IgM secretion by B-1b B cells, and additional studies in humans suggest that reduced levels of IgM may contribute to improved insulin sensitivity. While these findings are consistent with the previously defined role for $\operatorname{lgM}$ as a protector against inflammation and chronic disease ${ }^{121}$, more work is needed to uncover the mechanism(s) by which IgM functions in adipose tissue (Figure 20).

One possibility is that $\lg \mathrm{M}$ assists with dead cell clearance and maintaining local tissue homeostasis. In adult humans, billions of dead cells must be cleared every day - it is estimated that throughout the body, roughly one million cells undergo apoptosis per second ${ }^{249}$. Despite this remarkable amount of cell turnover, removal of dead cells occurs so quickly that uncleared apoptotic cells are rarely observed in healthy tissue ${ }^{249}$. However, defective removal of apoptotic cells results in elevated inflammation, and can lead to autoimmune 


\begin{tabular}{|l|l|}
\hline $\begin{array}{l}\text { Possible roles for IgM } \\
\text { in adipose tissue }\end{array}$ & Remaining questions \\
\hline Clear apoptotic cells & $\begin{array}{l}\text {-How are dead adipocytes } \\
\text { removed? } \\
\text {-Can IgM reduce dead cell } \\
\text { accumulation in adipose } \\
\text { tissue? }\end{array}$ \\
\hline & $\begin{array}{l}\text { Inhibit macrophage } \\
\text { activation }\end{array}$ \\
& $\begin{array}{l}\text {-Can lgM inhibit adipose } \\
\text { tissue macrophage- } \\
\text { derived inflammatory } \\
\text { cytokine production? } \\
\text {-Does IgM directly bind } \\
\text { M1 macrophages? To } \\
\text { what receptor? }\end{array}$ \\
& $\begin{array}{l}\text {-If binding occurs, does it } \\
\text { depend on antigen } \\
\text { specificity? }\end{array}$ \\
\hline & $\begin{array}{l}\text {-What receptor does lgM } \\
\text { bind? } \\
\text { Enhance adipocyte } \\
\text { function }\end{array}$ \\
& $\begin{array}{l}\text {-Can lgM rescue glucose } \\
\text { uptake and lipogenesis in } \\
\text { insulin-resistant } \\
\text { adipocytes? }\end{array}$ \\
&
\end{tabular}


Figure 20. Possible functions for $\lg M$ antibodies in adipose tissue. $\lg M$ is known to clear apoptotic cells, inhibit macrophage activation, and enhance adipocyte function. Studies are needed to further evaluate how $\operatorname{lgM}$ acts in adipose tissue in vivo. 
diseases including SLE ${ }^{126,127}$, which is associated with insulin resistance in mice 250,251 and humans ${ }^{252}$. In the same study described above by Winer and colleagues ${ }^{81}$, analysis of $\lg G$ autoantibodies in obese insulin-resistant and obese insulin-sensitive patients revealed that most autoantibodies enriched in the insulin-resistant cohort recognized intracellular proteins, suggestive of impaired dead cell clearance. Together, these findings suggest that in addition to being primary sites of inflammation, uncleared dead cells in obese adipose tissue might contribute to the pathogenic $\lg G$ response observed in obesity.

Secreted IgM is an important mediator of dead cell clearance and tissue homeostasis, and slgM $^{-/-}$mice also develop an SLE-like phenotype ${ }^{129,253}$. Cell surface expression patterns change during apoptosis, and IgM antibodies specific for moieties present on apoptotic, but not healthy, cells promote apoptotic cell clearance ${ }^{254}$. An example of such antibodies are members of the T15-IgM family that recognize the PC phospholipid that is expressed during the early stages of apoptosis. T15-IgM binds apoptotic cells and facilitates the binding of $\mathrm{C} 1 \mathrm{q}$ and mannose-binding lectin $(\mathrm{MBL})^{119,120,255}$ - two proteins that assist phagocyte-mediated apoptotic cell clearance $256-259.715-\operatorname{lgM}$ has been shown to promote apoptotic cell phagocytosis both in vitro ${ }^{120}$ and increase defective phagocytosis in vivo in $\mathrm{uMT}^{119}$ and $\mathrm{slgM}^{-/-123}$ mice, suggesting that IgMmediating apoptotic cell clearance is an important physiological process. In addition to PC-IgM antibodies, IgM specific for MDA has been shown to facilitate apoptotic cell clearance in Rag1\% mice ${ }^{109}$. Furthermore, IgM antibodies that preferentially bind apoptotic cells have been identified ${ }^{260-262}$, and there are known 
IgM clones specific for apoptotic cell surface markers such as cardiolipin, phosphatidylserine, and Annexin $\mathrm{V}^{263-266}$, suggesting that multiple natural antibodies may participate in the removal of dead cells and thereby prevent downstream inflammation and tissue destruction.

Likely due to a combination of the inflammatory and hypoxic microenvironment of obese adipose tissue, along with the physical demands of excess lipid storage, the progression of obesity strongly correlates with increased adipocyte death in mice and humans ${ }^{190,191,267}$. Interestingly, reduction in serum concentrations of MBL strongly correlates with indices of inflammation and reduced insulin sensitivity in mice and humans ${ }^{268}$, and genetic MBL polymorphisms associate with gestational diabetes ${ }^{269}$, suggesting that reduced concentration or function of apoptotic clearance machinery can impact glucose metabolism. CLS consisting of M1 macrophages surrounding uncleared dead adipocytes are a hallmark of obese adipose tissue, and contribute a major fraction of adipose-derived pro-inflammatory cytokines ${ }^{270}$. Several studies have shown that mice containing global ${ }^{267}$ and adipocyte-specific ${ }^{271}$ deletions of proapoptotic genes have reduced adipose tissue inflammation and display improved glucose homeostasis compared to controls, supporting the hypothesis that adipocyte death contributes to metabolic disease.

It is currently unknown whether IgM participates in removing apoptotic cells in adipose tissue. IgM antibodies have been reported to localize to $\mathrm{CLS}^{81}$, but these findings must be confirmed using $\mathrm{slg}^{-1}{ }^{-}$negative controls to avoid the possibility that this staining was detecting $\lg ^{\text {hi }}$ B-1 B cells within CLS. Additional 
studies that quantify CLS or measure apoptotic cells through TUNEL staining in adipose tissue of HFD slgM-^mice are also needed to determine if loss of secreted IgM leads to a noticeable reduction in apoptotic cell accumulation. If this were the case, follow-up experiments that transfer sorted B-1a or B-1b B cells

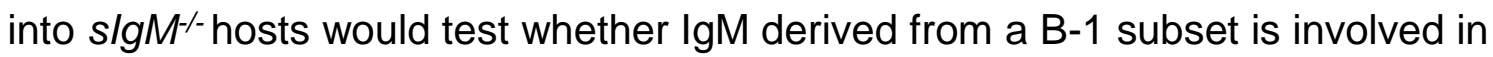
preventing apoptotic cell accumulation in adipose tissue. While infusion of IgM antibodies known to assist in dead cell clearance (such as T15-lgM or IgM against MDA-LDL) into $s / g M^{-/-}$recipients would allow for further delineation into whether these antibodies localize to sites of dead adipocytes and promote their clearance, such experiments are costly and require large quantities of antibody. While CLS identification and TUNEL staining can detect uncleared dead adipocytes, relatively little is known regarding the apoptotic process in adipocytes or the physical factors regulating the removal of dead cells from adipose tissue. Recent studies suggest that dying adipocytes share much of the known apoptotic machinery of other cells ${ }^{272}$, but gene overexpression and deletion studies are needed to confirm this. Furthermore, thorough microarray analysis is needed to identify any unique factors to adipocyte apoptosis that may have been missed by studies focusing on well-studied pathways. Understanding how programmed cell death works in adipocytes may allow for cell-specific antagonists of adipocyte apoptosis aimed at improving insulin sensitivity during periods of over-nutrition. In addition, the average adipocyte has a diameter of about $100 \mu \mathrm{m}$, and can double or triple in size during obesity. As most apoptosis studies focus on clearing $6 \mu \mathrm{m}$ apoptotic thymocytes, obvious physical hurdles must be overcome to remove 
these giant, lipid-laden cells. Co-culture studies could be performed to test if IgM promotes adipocyte clearance. In this experiment, labeled apoptotic adipocytes would be incubated with macrophages and treated with either T15-IgM or vehicle control. All studies would be performed in the presence of serum from $\mathrm{slgM}^{-/ \text {, }}$ Rag $1 \%$, or $\mu \mathrm{MT}$ mice to provide the complement factors, but not IgM antibodies, required for IgM-mediated phagocytosis ${ }^{119,}{ }^{120}$. After several hours, adipocyte phagocytosis could be quantified by flow cytometry or immunofluorescent microscopy. Results of these studies, along with others that test specific roles of M1 and M2 macrophages in adipocyte clearance, will enhance our understanding of how to improve adipose tissue homeostasis when local cell death increases during obesity.

In addition to promoting apoptotic cell clearance, IgM antibodies have reported direct anti-inflammatory properties. In a murine model of atherosclerosis - another disease characterized by chronic inflammation - B-1a B cells adoptively transferred into splenectomized hosts reduced aortic plaque size and macrophage content in a mechanism dependent on their ability to secrete $\lg ^{130}$. Interestingly, IgM antibodies have been identified in atherosclerotic lesions ${ }^{109}$ and EO6 - a specific IgM clone of the T15 family ${ }^{116}$ - was able to inhibit macrophage uptake of oxidized LDL and prevent foam cell formation ${ }^{185,273}$. In a separate study, T15/E06 IgM infusion attenuated the development of joint inflammation and cartilage damage in a mouse model of arthritis ${ }^{119}$. Interestingly, EO6 was also able to prevent OxPAPC-induced macrophage activation ${ }^{274}$ and TLRmediated dendritic cell and macrophage activation ${ }^{119}$, suggesting that IgM 
antibodies may directly reduce inflammatory cell activity. Consistent with these findings, preliminary studies in our laboratory suggest that treatment of omental adipose tissue with IgM or EO6 may reduce TNFa production by M1 macrophages (Figure 21). While no mechanism for this anti-inflammatory activity has been proposed, the previously designated Fas apoptotic inhibitory molecule 3 (TOSO) $)^{275}$ was recently shown to act as an IgM Fc receptor $(\mathrm{Fc} \mu \mathrm{R})^{276,277}$ and to be involved in pro-inflammatory TLR4 signaling ${ }^{278}$. It is possible that $\operatorname{lgM}$ can blunt inflammatory macrophage signaling through TOSO binding. Additional studies are needed to test if IgM antibodies can regulate adipose tissue macrophage inflammation, and whether any effect on activity is dependent on IgM binding to this novel Fc $\mu R$.

A third mechanism by which IgM may regulate adipose tissue function is through direct interaction with adipocytes. Studies in the 1980s showed that polyclonal human IgM was able induce glucose uptake and stimulate lipogenesis in rat adipocytes better than insulin ${ }^{192,279}$. Interestingly, competition assays showed that IgM did not compete with insulin binding, suggesting that it acts through a different receptor ${ }^{279}$. Additional work by the same group revealed that IgG antibodies have a similar metabolic effect on adipocytes ${ }^{280}$, suggesting that 
M1 macrophages

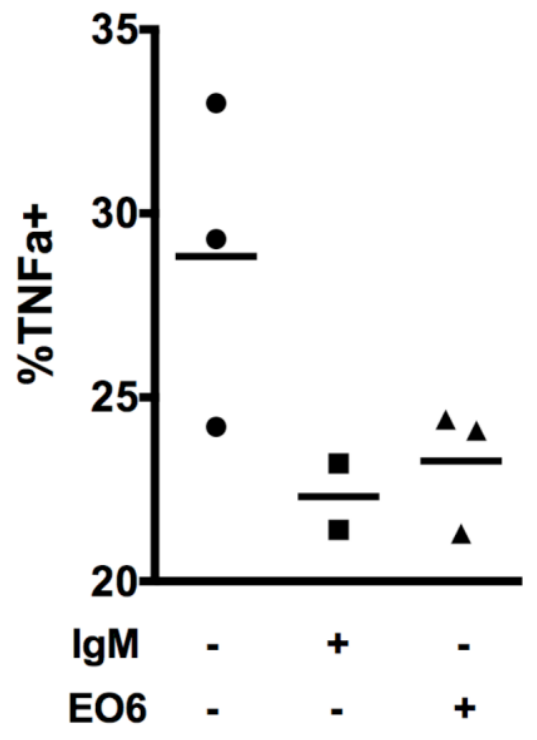

M2 macrophages

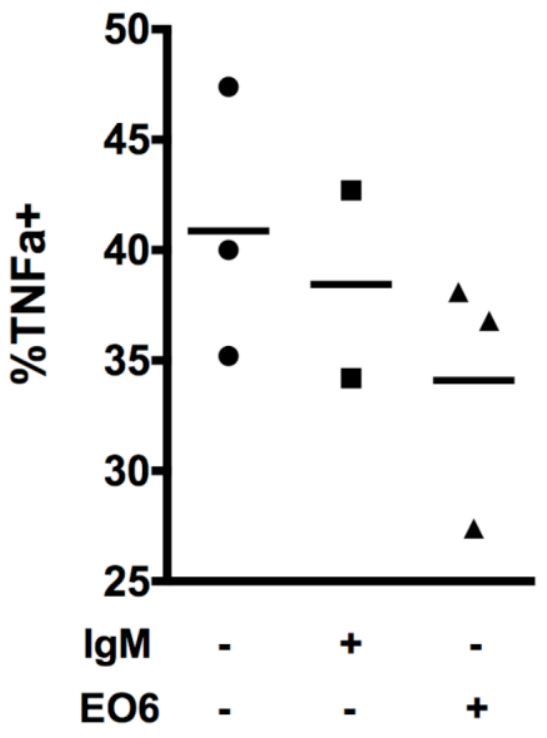


Figure 21. IgM antibodies may attenuate omental adipose tissue M1 macrophage TNFa secretion. Whole omental adipose tissue explants from C57BI/6 mice fed a HFD for three weeks treated overnight with either IgM isotype or EO6 (T15-lgM). Explants were then activated with PMA/lonomycin in the presence of Brefeldin A for five hours. F4/80 ${ }^{+} \mathrm{CD} 11 \mathrm{~b}^{+} \mathrm{CD} 11 \mathrm{c}^{+} \mathrm{M} 1$ (left) and F4/80+CD11 ${ }^{+}$CD11 $c^{-}$M2 (right) TNFa expression was quantified by flow cytometry. Each dot represents one mouse. 
regulation may not be limited to $\lg M$ antibodies. A more recent study identified IgG Fc receptors on the cell membranes of human adipocytes and showed that Fc fragments of IgG antibodies were sufficient to stimulate lipogenesis and reduce IL-1 $\beta$ and IL-6 expression in adipocytes ${ }^{76}$. Together, these findings suggest that antibodies may have important regulatory effects on adipocytes, and follow-up studies are needed to determine whether adipocytes express TOSO or other receptors that specifically bind IgM. In addition, determining whether IgM treatment can rescue insulin-mediated metabolic function of insulin resistant adipocytes will be of great interest and has the potential to uncover novel signaling pathways that could be exploited for future therapeutic treatment.

\section{Additional characterization of human $C D 20^{+} C D 27^{+} C D 43^{+} B$ cells is needed.}

While the existence of a human B-1 B cell equivalent has long been hypothesized, several factors have made its identification elusive. Unlike in mice, no single cell surface marker is known to identify human B-1 B cells. Murine B-1 B cells were first discovered as a unique $\mathrm{CD}^{+} \mathrm{B}$ cell that spontaneously secreted $\lg \mathrm{M}^{281}$. Using CD5 expression as a starting point, subsequent studies were able to identify characteristics and surface expression patterns specific for murine B-1 B cells. These studies led to the identification of a CD5- B-1 B cell 282 and the distinction between $\mathrm{CD}^{+} \mathrm{B}-1 \mathrm{a}$ and $\mathrm{CD} 5^{-} \mathrm{B}-1 \mathrm{~b}$ B cells in mice. In humans however, while CD5 is found on IgM-producing B cells ${ }^{283,284}$, it is also expressed by other B cell subsets ${ }^{285,286}$, and no other B-1 distinguishing marker has been proposed. In addition to complications arising from differences in murine and 
human B cell surface expression, much of our understanding of B-1 B cells in mice stems from unlimited access to bone marrow, peritoneal fluid, and lymphoid tissue. For obvious ethical and practical reasons, the majority of immune analysis in humans comes from studies of circulating cells. As few circulating B-1 B cells are found in mice, it is not surprising that our knowledge of B-1 B cells in humans has lagged behind.

While Griffin and colleagues' discovery of a novel human CD20 ${ }^{+} \mathrm{CD} 27^{+} \mathrm{CD} 43^{+} \mathrm{B}$ cell population ${ }^{90}$ is exciting, follow-up confirmatory studies by other groups will be important. Results from our studies described in chapter 4 indicate additional similarities between this B cell population and murine B-1 B cells, most notably their enrichment in omental adipose tissue and correlation with circulating natural IgM antibodies. Future studies to examine whether these B cells are a source of natural antibodies, if they have the capacity to self-renew, and where else they may be located will be instrumental in determining their true nature. Importantly, now that this cell has been identified, multi-color flow cytometry, microarray analysis, and the recently introduced mass cytometry technology ${ }^{241}$ can be used to further characterize its gene expression pattern, antibody repertoire, and surface marker phenotype.

The identification of $\mathrm{CD} 20^{+} \mathrm{CD} 27^{+} \mathrm{CD} 43^{+} \mathrm{B}$ cells in human omental adipose tissue highlights the need for additional analysis of these cells in the context of obesity and insulin resistance. Due to the relatively low numbers of patients that we have been able to analyze by flow cytometry, our study is incapable of delineating any correlations between $\mathrm{CD} 20^{+} \mathrm{CD} 27^{+} \mathrm{CD} 43^{+} \mathrm{B}$ cells 
and clinical outcomes. However, based on our murine findings, we would hypothesize that increased numbers and/or IgM production from these B cells would correlate with reduced adipose tissue inflammation and an improved metabolic phenotype. As recent evidence suggests that obesity and T2D alters B cell activity, further study is needed to evaluate how $\mathrm{CD} 20^{+} \mathrm{CD} 27^{+} \mathrm{CD} 43^{+} \mathrm{B}$ cells in omental adipose are altered in this context. B cells from T2D patients secrete higher levels of IL-8, attenuated amounts of IL-10, and are more equipped to induce IL-17 expression in T cells ${ }^{77,101}$, indicating a pro-inflammatory phenotype. Obese individuals also have significantly reduced circulating lgM compared to age-matched controls, suggesting a reduction in either number or function of IgM-producing B cells ${ }^{287}$. Since a significant fraction of our patient cohort were obese and either diabetic or non diabetic with metabolic syndrome, additional studies are needed to determine whether $\mathrm{CD} 20^{+} \mathrm{CD} 27^{+} \mathrm{CD} 43^{+} \mathrm{B}$ cell number or function is different in omental fat of healthy individuals. Results from these studies may uncover novel relationships between these B cells and metabolic disease, and allow for further insight into whether this newly discovered B cell population could be a potential immunotherapy agent. 
CHAPTER 6:

References 
1. Kahn BB, Flier JS. Obesity and insulin resistance. J Clin Invest. 2000;106:473481

2. Rocha VZ, Libby P. Obesity, inflammation, and atherosclerosis. Nat Rev Cardiol. 2009;6:399-409

3. Lee EB. Obesity, leptin, and alzheimer's disease. Ann N Y Acad Sci. 2011;1243:15-29

4. Mathieu P, Lemieux I, Despres JP. Obesity, inflammation, and cardiovascular risk. Clin Pharmacol Ther. 2010;87:407-416

5. Kershaw EE, Flier JS. Adipose tissue as an endocrine organ. J Clin Endocrinol Metab. 2004;89:2548-2556

6. Mohamed-Ali V, Pinkney JH, Coppack SW. Adipose tissue as an endocrine and paracrine organ. Int J Obes Relat Metab Disord. 1998;22:1145-1158

7. Bluher M. The inflammatory process of adipose tissue. Pediatric endocrinology reviews : PER. 2008;6:24-31

8. Bluher M. Adipose tissue dysfunction in obesity. Exp Clin Endocrinol Diabetes. 2009;117:241-250

9. Hosogai N, Fukuhara A, Oshima K, Miyata Y, Tanaka S, Segawa K, Furukawa S, Tochino Y, Komuro R, Matsuda M, Shimomura I. Adipose tissue hypoxia in obesity and its impact on adipocytokine dysregulation. Diabetes. 2007;56:901-911

10. Maury E, Brichard SM. Adipokine dysregulation, adipose tissue inflammation and metabolic syndrome. Mol Cell Endocrinol. 2010;314:1-16

11. Osborn 0, Olefsky JM. The cellular and signaling networks linking the immune system and metabolism in disease. Nat Med. 2012;18:363-374

12. Semenza GL. Hif-1 and human disease: One highly involved factor. Genes Dev. 2000;14:1983-1991

13. Skurk T, Alberti-Huber C, Herder C, Hauner H. Relationship between adipocyte size and adipokine expression and secretion.J Clin Endocrinol Metab. 2007;92:1023-1033

14. Wang B, Wood IS, Trayhurn P. Dysregulation of the expression and secretion of inflammation-related adipokines by hypoxia in human adipocytes. Pflugers Archiv : European journal of physiology. 2007;455:479-492 
15. Ye J, Gao Z, Yin J, He Q. Hypoxia is a potential risk factor for chronic inflammation and adiponectin reduction in adipose tissue of ob/ob and dietary obese mice. Am J Physiol Endocrinol Metab. 2007;293:E1118-1128

16. Qi L, Saberi M, Zmuda E, Wang Y, Altarejos J, Zhang X, Dentin R, Hedrick S, Bandyopadhyay G, Hai T, Olefsky J, Montminy M. Adipocyte creb promotes insulin resistance in obesity. Cell Metab. 2009;9:277-286

17. Sabio G, Das M, Mora A, Zhang Z, Jun JY, Ko HJ, Barrett T, Kim JK, Davis RJ. A stress signaling pathway in adipose tissue regulates hepatic insulin resistance. Science. 2008;322:1539-1543

18. Zhang X, Xu A, Chung SK, Cresser JH, Sweeney G, Wong RL, Lin A, Lam KS. Selective inactivation of c-jun nh2-terminal kinase in adipose tissue protects against diet-induced obesity and improves insulin sensitivity in both liver and skeletal muscle in mice. Diabetes. 2011;60:486-495

19. Abel ED, Peroni O, Kim JK, Kim YB, Boss O, Hadro E, Minnemann T, Shulman GI, Kahn BB. Adipose-selective targeting of the glut4 gene impairs insulin action in muscle and liver. Nature. 2001;409:729-733

20. Kamei N, Tobe K, Suzuki R, Ohsugi M, Watanabe T, Kubota N, OhtsukaKowatari N, Kumagai K, Sakamoto K, Kobayashi M, Yamauchi T, Ueki K, Oishi Y, Nishimura S, Manabe I, Hashimoto H, Ohnishi Y, Ogata H, Tokuyama K, Tsunoda M, Ide T, Murakami K, Nagai R, Kadowaki T. Overexpression of monocyte chemoattractant protein- 1 in adipose tissues causes macrophage recruitment and insulin resistance. J Biol Chem. 2006;281:26602-26614

21. Arkan MC, Hevener AL, Greten FR, Maeda S, Li ZW, Long JM, Wynshaw-Boris A, Poli G, Olefsky J, Karin M. Ikk-beta links inflammation to obesity-induced insulin resistance. Nat Med. 2005;11:191-198

22. Bruning JC, Michael MD, Winnay JN, Hayashi T, Horsch D, Accili D, Goodyear LJ, Kahn CR. A muscle-specific insulin receptor knockout exhibits features of the metabolic syndrome of niddm without altering glucose tolerance. Mol Cell. 1998;2:559-569

23. Matsusue K, Haluzik M, Lambert G, Yim SH, Gavrilova O, Ward JM, Brewer B, Jr., Reitman ML, Gonzalez FJ. Liver-specific disruption of ppargamma in leptin-deficient mice improves fatty liver but aggravates diabetic phenotypes. J Clin Invest. 2003;111:737-747

24. Sabio G, Kennedy NJ, Cavanagh-Kyros J, Jung DY, Ko HJ, Ong H, Barrett T, Kim JK, Davis RJ. Role of muscle c-jun nh2-terminal kinase 1 in obesity-induced insulin resistance. Mol Cell Biol. 2010;30:106-115 
25. Vague J. La différenciation sexuelle, facteur déterminant des formes de l'obésité. La Presse medicale. 1947;55:339

26. Vague J. The degree of masculine differentiation of obesities: A factor determining predisposition to diabetes, atherosclerosis, gout, and uric calculous disease. Am J Clin Nutr. 1956;4:20-34

27. Frayn KN. Visceral fat and insulin resistance--causative or correlative? The British journal of nutrition. 2000;83 Suppl 1:S71-77

28. Wajchenberg BL. Subcutaneous and visceral adipose tissue: Their relation to the metabolic syndrome. Endocrine reviews. 2000;21:697-738

29. Tchernof A, Despres JP. Pathophysiology of human visceral obesity: An update. Physiological reviews. 2013;93:359-404

30. Ohlson LO, Larsson B, Svardsudd K, Welin L, Eriksson H, Wilhelmsen L, Bjorntorp P, Tibblin G. The influence of body fat distribution on the incidence of diabetes mellitus. 13.5 years of follow-up of the participants in the study of men born in 1913. Diabetes. 1985;34:1055-1058

31. Coon PJ, Rogus EM, Drinkwater D, Muller DC, Goldberg AP. Role of body fat distribution in the decline in insulin sensitivity and glucose tolerance with age. J Clin Endocrinol Metab. 1992;75:1125-1132

32. Carey DG, Jenkins AB, Campbell LV, Freund J, Chisholm DJ. Abdominal fat and insulin resistance in normal and overweight women: Direct measurements reveal a strong relationship in subjects at both low and high risk of niddm. Diabetes. 1996;45:633-638

33. Gastaldelli A, Miyazaki Y, Pettiti M, Matsuda M, Mahankali S, Santini E, DeFronzo RA, Ferrannini E. Metabolic effects of visceral fat accumulation in type 2 diabetes. J Clin Endocrinol Metab. 2002;87:5098-5103

34. Gabriely I, Ma XH, Yang XM, Atzmon G, Rajala MW, Berg AH, Scherer P, Rossetti L, Barzilai N. Removal of visceral fat prevents insulin resistance and glucose intolerance of aging: An adipokine-mediated process? Diabetes. 2002;51:2951-2958

35. Barzilai N, She L, Liu BQ, Vuguin P, Cohen P, Wang J, Rossetti L. Surgical removal of visceral fat reverses hepatic insulin resistance. Diabetes. 1999;48:94-98

36. Kelley DE. Thermodynamics, liposuction, and metabolism. $N$ Engl J Med. 2004;350:2542-2544 
37. Klein S, Fontana L, Young VL, Coggan AR, Kilo C, Patterson BW, Mohammed BS. Absence of an effect of liposuction on insulin action and risk factors for coronary heart disease. $N$ Engl J Med. 2004;350:2549-2557

38. Williamson RT. On the treatment of glycosuria and diabetes mellitus with sodium salicylate. Br Med J. 1901;1:760-762

39. Baron SH. Salicylates as hypoglycemic agents. Diabetes Care. 1982;5:64-71

40. Raymond RM, Klein DM, Gibbons DA, Jacobs HK, Emerson TE, Jr. Skeletal muscle insulin unresponsiveness during chronic hyperdynamic sepsis in the dog. The Journal of trauma. 1985;25:845-855

41. Lang CH, Bagby GJ, Blakesley HL, Spitzer JJ. Inhibition of eicosanoid production by bw755c does not attenuate sepsis-induced alterations in glucose kinetics. Circulatory shock. 1987;22:105-113

42. Raymond RM, Harkema JM, Emerson TE, Jr. In vivo skeletal muscle insulin resistance during e coli endotoxin shock in the dog. Circulatory shock. $1981 ; 8: 425-433$

43. Black PR, Brooks DC, Bessey PQ, Wolfe RR, Wilmore DW. Mechanisms of insulin resistance following injury. Annals of surgery. 1982;196:420-435

44. Stephens JM, Pekala PH. Transcriptional repression of the glut4 and c/ebp genes in 3t3-11 adipocytes by tumor necrosis factor-alpha. J Biol Chem. $1991 ; 266: 21839-21845$

45. Hotamisligil GS, Shargill NS, Spiegelman BM. Adipose expression of tumor necrosis factor-alpha: Direct role in obesity-linked insulin resistance. Science. 1993;259:87-91

46. Feinstein R, Kanety H, Papa MZ, Lunenfeld B, Karasik A. Tumor necrosis factor-alpha suppresses insulin-induced tyrosine phosphorylation of insulin receptor and its substrates. J Biol Chem. 1993;268:26055-26058

47. Hotamisligil GS, Murray DL, Choy LN, Spiegelman BM. Tumor necrosis factor alpha inhibits signaling from the insulin receptor. Proc Natl Acad Sci U S A. 1994;91:4854-4858

48. Kanety H, Feinstein R, Papa MZ, Hemi R, Karasik A. Tumor necrosis factor alpha-induced phosphorylation of insulin receptor substrate-1 (irs-1). Possible mechanism for suppression of insulin-stimulated tyrosine phosphorylation of irs-1. J Biol Chem. 1995;270:23780-23784

49. Kroder G, Bossenmaier B, Kellerer M, Capp E, Stoyanov B, Muhlhofer A, Berti L, Horikoshi H, Ullrich A, Haring H. Tumor necrosis factor-alpha- and 
hyperglycemia-induced insulin resistance. Evidence for different mechanisms and different effects on insulin signaling. J Clin Invest. 1996;97:1471-1477

50. Uysal KT, Wiesbrock SM, Marino MW, Hotamisligil GS. Protection from obesity-induced insulin resistance in mice lacking tnf-alpha function. Nature. 1997;389:610-614

51. Ventre J, Doebber T, Wu M, MacNaul K, Stevens K, Pasparakis M, Kollias G, Moller DE. Targeted disruption of the tumor necrosis factor-alpha gene: Metabolic consequences in obese and nonobese mice. Diabetes. 1997;46:1526-1531

52. Dandona P, Weinstock R, Thusu K, Abdel-Rahman E, Aljada A, Wadden T. Tumor necrosis factor-alpha in sera of obese patients: Fall with weight loss. $J$ Clin Endocrinol Metab. 1998;83:2907-2910

53. Hak AE, Stehouwer CD, Bots ML, Polderman KH, Schalkwijk CG, Westendorp IC, Hofman A, Witteman JC. Associations of c-reactive protein with measures of obesity, insulin resistance, and subclinical atherosclerosis in healthy, middle-aged women. Arterioscler Thromb Vasc Biol. 1999;19:1986-1991

54. Festa A, D'Agostino R, Jr., Howard G, Mykkanen L, Tracy RP, Haffner SM. Chronic subclinical inflammation as part of the insulin resistance syndrome: The insulin resistance atherosclerosis study (iras). Circulation. 2000;102:4247

55. Barzilay JI, Abraham L, Heckbert SR, Cushman M, Kuller LH, Resnick HE, Tracy RP. The relation of markers of inflammation to the development of glucose disorders in the elderly: The cardiovascular health study. Diabetes. 2001;50:2384-2389

56. Kubaszek A, Pihlajamaki J, Komarovski V, Lindi V, Lindstrom J, Eriksson J, Valle TT, Hamalainen H, Ilanne-Parikka P, Keinanen-Kiukaanniemi S, Tuomilehto J, Uusitupa M, Laakso M. Promoter polymorphisms of the tnfalpha (g-308a) and il-6 (c-174g) genes predict the conversion from impaired glucose tolerance to type 2 diabetes: The finnish diabetes prevention study. Diabetes. 2003;52:1872-1876

57. Pradhan AD, Manson JE, Rifai N, Buring JE, Ridker PM. C-reactive protein, interleukin 6 , and risk of developing type 2 diabetes mellitus. JAMA. 2001;286:327-334

58. Duncan BB, Schmidt MI, Pankow JS, Ballantyne CM, Couper D, Vigo A, Hoogeveen R, Folsom AR, Heiss G. Low-grade systemic inflammation and the development of type 2 diabetes: The atherosclerosis risk in communities study. Diabetes. 2003;52:1799-1805 
59. Hamilton BS, Paglia D, Kwan AY, Deitel M. Increased obese mrna expression in omental fat cells from massively obese humans. Nat Med. 1995;1:953-956

60. Hotamisligil GS, Arner P, Caro JF, Atkinson RL, Spiegelman BM. Increased adipose tissue expression of tumor necrosis factor-alpha in human obesity and insulin resistance. J Clin Invest. 1995;95:2409-2415

61. Kern PA, Saghizadeh M, Ong JM, Bosch RJ, Deem R, Simsolo RB. The expression of tumor necrosis factor in human adipose tissue. Regulation by obesity, weight loss, and relationship to lipoprotein lipase. J Clin Invest. 1995;95:2111-2119

62. Shimomura I, Funahashi T, Takahashi M, Maeda K, Kotani K, Nakamura T, Yamashita S, Miura M, Fukuda Y, Takemura K, Tokunaga K, Matsuzawa Y. Enhanced expression of pai-1 in visceral fat: Possible contributor to vascular disease in obesity. Nat Med. 1996;2:800-803

63. Mohamed-Ali V, Goodrick S, Rawesh A, Katz DR, Miles JM, Yudkin JS, Klein S, Coppack SW. Subcutaneous adipose tissue releases interleukin-6, but not tumor necrosis factor-alpha, in vivo. J Clin Endocrinol Metab. 1997;82:41964200

64. Samad F, Yamamoto K, Pandey M, Loskutoff DJ. Elevated expression of transforming growth factor-beta in adipose tissue from obese mice. Mol Med. 1997;3:37-48

65. Fried SK, Bunkin DA, Greenberg AS. Omental and subcutaneous adipose tissues of obese subjects release interleukin-6: Depot difference and regulation by glucocorticoid. J Clin Endocrinol Metab. 1998;83:847-850

66. Cousin B, Andre M, Casteilla L, Penicaud L. Altered macrophage-like functions of preadipocytes in inflammation and genetic obesity. J Cell Physiol. 2001;186:380-386

67. Bornstein SR, Abu-Asab M, Glasow A, Path G, Hauner H, Tsokos M, Chrousos GP, Scherbaum WA. Immunohistochemical and ultrastructural localization of leptin and leptin receptor in human white adipose tissue and differentiating human adipose cells in primary culture. Diabetes. 2000;49:532-538

68. Weisberg SP, McCann D, Desai M, Rosenbaum M, Leibel RL, Ferrante AW, Jr. Obesity is associated with macrophage accumulation in adipose tissue. J Clin Invest. 2003;112:1796-1808

69. Xu H, Barnes GT, Yang Q, Tan G, Yang D, Chou CJ, Sole J, Nichols A, Ross JS, Tartaglia LA, Chen $\mathrm{H}$. Chronic inflammation in fat plays a crucial role in the development of obesity-related insulin resistance. J Clin Invest. 2003;112:1821-1830 
70. Chawla A, Nguyen KD, Goh YP. Macrophage-mediated inflammation in metabolic disease. Nat Rev Immunol. 2011;11:738-749

71. Dalmas E, Clement K, Guerre-Millo M. Defining macrophage phenotype and function in adipose tissue. Trends Immunol. 2011;32:307-314

72. Chatzigeorgiou A, Karalis KP, Bornstein SR, Chavakis T. Lymphocytes in obesity-related adipose tissue inflammation. Diabetologia. 2012

73. Schipper HS, Prakken B, Kalkhoven E, Boes M. Adipose tissue-resident immune cells: Key players in immunometabolism. Trends Endocrinol Metab. 2012;23:407-415

74. Nikolajczyk BS, Jagannathan-Bogdan M, Shin H, Gyurko R. State of the union between metabolism and the immune system in type 2 diabetes. Genes Immun. 2011;12:239-250

75. Nikolajczyk BS, Jagannathan-Bogdan M, Denis GV. The outliers become a stampede as immunometabolism reaches a tipping point. Immunol Rev. 2012;249:253-275

76. Palming J, Gabrielsson BG, Jennische E, Smith U, Carlsson B, Carlsson LM, Lonn M. Plasma cells and fc receptors in human adipose tissue--lipogenic and anti-inflammatory effects of immunoglobulins on adipocytes. Biochem Biophys Res Commun. 2006;343:43-48

77. Defuria J, Belkina AC, Jagannathan-Bogdan M, Snyder-Cappione J, Carr JD, Nersesova YR, Markham D, Strissel KJ, Watkins AA, Zhu M, Allen J, Bouchard J, Toraldo G, Jasuja R, Obin MS, McDonnell ME, Apovian C, Denis GV, Nikolajczyk BS. B cells promote inflammation in obesity and type 2 diabetes through regulation of t-cell function and an inflammatory cytokine profile. Proc Natl Acad Sci U S A. 2013;110:5133-5138

78. Duffaut C, Galitzky J, Lafontan M, Bouloumie A. Unexpected trafficking of immune cells within the adipose tissue during the onset of obesity. Biochem Biophys Res Commun. 2009;384:482-485

79. Gabrielsson BG, Johansson JM, Lonn M, Jernas M, Olbers T, Peltonen M, Larsson I, Lonn L, Sjostrom L, Carlsson B, Carlsson LM. High expression of complement components in omental adipose tissue in obese men. Obes Res. 2003;11:699-708

80. McDonnell ME, Ganley-Leal LM, Mehta A, Bigornia SJ, Mott M, Rehman Q, Farb MG, Hess DT, Joseph L, Gokce N, Apovian CM. B lymphocytes in human subcutaneous adipose crown-like structures. Obesity (Silver Spring). 2012;20:1372-1378 
81. Winer DA, Winer S, Shen L, Wadia PP, Yantha J, Paltser G, Tsui H, Wu P, Davidson MG, Alonso MN, Leong HX, Glassford A, Caimol M, Kenkel JA, Tedder TF, McLaughlin T, Miklos DB, Dosch HM, Engleman EG. B cells promote insulin resistance through modulation of $t$ cells and production of pathogenic igg antibodies. Nat Med. 2011;17:610-617

82. Rangel-Moreno J, Moyron-Quiroz JE, Carragher DM, Kusser K, Hartson L, Moquin A, Randall TD. Omental milky spots develop in the absence of lymphoid tissue-inducer cells and support $\mathrm{b}$ and $\mathrm{t}$ cell responses to peritoneal antigens. Immunity. 2009;30:731-743

83. McHeyzer-Williams M, Okitsu S, Wang N, McHeyzer-Williams L. Molecular programming of b cell memory. Nat Rev Immunol. 2012;12:24-34

84. McHeyzer-Williams LJ, McHeyzer-Williams MG. Antigen-specific memory b cell development. Annu Rev Immunol. 2005;23:487-513

85. Tangye SG, Tarlinton DM. Memory b cells: Effectors of long-lived immune responses. Eur J Immunol. 2009;39:2065-2075

86. Pillai S, Cariappa A, Moran ST. Marginal zone b cells. Annu Rev Immunol. 2005;23:161-196

87. Hayakawa K, Hardy RR, Herzenberg LA, Herzenberg LA. Progenitors for ly-1 $\mathrm{b}$ cells are distinct from progenitors for other b cells. J Exp Med.

1985;161:1554-1568

88. Godin IE, Garcia-Porrero JA, Coutinho A, Dieterlen-Lievre F, Marcos MA. Paraaortic splanchnopleura from early mouse embryos contains b1a cell progenitors. Nature. 1993;364:67-70

89. Herzenberg LA. B-1 cells: The lineage question revisited. Immunol Rev. 2000;175:9-22

90. Griffin DO, Holodick NE, Rothstein TL. Human b1 cells in umbilical cord and adult peripheral blood express the novel phenotype $\operatorname{cd} 20+\operatorname{cd} 27+\operatorname{cd} 43+$ cd70. J Exp Med. 2011;208:67-80

91. Deenen GJ, Kroese FG. Murine peritoneal ly-1 b cells do not turn over rapidly. Ann N Y Acad Sci. 1992;651:70-71

92. Alugupalli KR, Leong JM, Woodland RT, Muramatsu M, Honjo T, Gerstein RM. B1b lymphocytes confer t cell-independent long-lasting immunity. Immunity. 2004;21:379-390

93. Choi YS, Baumgarth N. Dual role for b-1a cells in immunity to influenza virus infection. J Exp Med. 2008;205:3053-3064 
94. Haas KM, Poe JC, Steeber DA, Tedder TF. B-1a and b-1b cells exhibit distinct developmental requirements and have unique functional roles in innate and adaptive immunity to s. Pneumoniae. Immunity. 2005;23:7-18

95. Stoehr AD, Schoen CT, Mertes MM, Eiglmeier S, Holecska V, Lorenz AK, Schommartz T, Schoen AL, Hess C, Winkler A, Wardemann H, Ehlers M. Tlr9 in peritoneal $b-1 b$ cells is essential for production of protective self-reactive igm to control th17 cells and severe autoimmunity. J Immunol. 2011;187:2953-2965

96. Baumgarth N. The double life of a b-1 cell: Self-reactivity selects for protective effector functions. Nat Rev Immunol. 2011;11:34-46

97. DiLillo DJ, Matsushita T, Tedder TF. B10 cells and regulatory b cells balance immune responses during inflammation, autoimmunity, and cancer. Ann NY Acad Sci. 2010;1183:38-57

98. Mauri C, Bosma A. Immune regulatory function of b cells. Annu Rev Immunol. 2012;30:221-241

99. Sasaki Y, Casola S, Kutok JL, Rajewsky K, Schmidt-Supprian M. Tnf family member b cell-activating factor (baff) receptor-dependent and -independent roles for baff in b cell physiology. J Immunol. 2004;173:2245-2252

100. Kawasaki K, Abe M, Tada F, Tokumoto Y, Chen S, Miyake T, Furukawa S, Matsuura B, Hiasa Y, Onji M. Blockade of b-cell-activating factor signaling enhances hepatic steatosis induced by a high-fat diet and improves insulin sensitivity. Lab Invest. 2013;93:311-321

101. Jagannathan M, McDonnell M, Liang Y, Hasturk H, Hetzel J, Rubin D, Kantarci A, Van Dyke TE, Ganley-Leal LM, Nikolajczyk BS. Toll-like receptors regulate b cell cytokine production in patients with diabetes. Diabetologia. 2010;53:1461-1471

102. Nishimura S, Manabe I, Takaki S, Nagasaki M, Otsu M, Yamashita H, Sugita J, Yoshimura K, Eto K, Komuro I, Kadowaki T, Nagai R. Adipose natural regulatory b cells negatively control adipose tissue inflammation. Cell Metab. 2013

103. Coutinho A, Kazatchkine MD, Avrameas S. Natural autoantibodies. Curr Opin Immunol. 1995;7:812-818

104. Herzenberg LA, Baumgarth N, Wilshire JA. B-1 cell origins and vh repertoire determination. Curr Top Microbiol Immunol. 2000;252:3-13 
105. Seidl KJ, MacKenzie JD, Wang D, Kantor AB, Kabat EA, Herzenberg LA, Herzenberg LA. Frequent occurrence of identical heavy and light chain ig rearrangements. Int Immunol. 1997;9:689-702

106. Vasconcellos R, Nobrega A, Haury M, Viale AC, Coutinho A. Genetic control of natural antibody repertoires: I. Igh, mhc and tcr beta loci. Eur J Immunol. 1998;28:1104-1115

107. Merbl Y, Zucker-Toledano M, Quintana FJ, Cohen IR. Newborn humans manifest autoantibodies to defined self molecules detected by antigen microarray informatics. J Clin Invest. 2007;117:712-718

108. Madi A, Hecht I, Bransburg-Zabary S, Merbl Y, Pick A, Zucker-Toledano M, Quintana FJ, Tauber AI, Cohen IR, Ben-Jacob E. Organization of the autoantibody repertoire in healthy newborns and adults revealed by system level informatics of antigen microarray data. Proc Natl Acad Sci U S A. 2009;106:14484-14489

109. Chou MY, Fogelstrand L, Hartvigsen K, Hansen LF, Woelkers D, Shaw PX, Choi J, Perkmann T, Backhed F, Miller YI, Horkko S, Corr M, Witztum JL, Binder CJ. Oxidation-specific epitopes are dominant targets of innate natural antibodies in mice and humans. J Clin Invest. 2009;119:1335-1349

110. Mouthon L, Nobrega A, Nicolas N, Kaveri SV, Barreau C, Coutinho A, Kazatchkine MD. Invariance and restriction toward a limited set of selfantigens characterize neonatal igm antibody repertoires and prevail in autoreactive repertoires of healthy adults. Proc Natl Acad Sci U S A. 1995;92:3839-3843

111. Hardy RR, Carmack CE, Shinton SA, Riblet RJ, Hayakawa K. A single vh gene is utilized predominantly in anti-brmrbc hybridomas derived from purified ly-1 b cells. Definition of the vh11 family. J Immunol. 1989;142:3643-3651

112. Mercolino TJ, Locke AL, Afshari A, Sasser D, Travis WW, Arnold LW, Haughton G. Restricted immunoglobulin variable region gene usage by normal ly-1 (cd5+) b cells that recognize phosphatidyl choline. J Exp Med. 1989;169:1869-1877

113. Wang H, Clarke SH. Positive selection focuses the vh12 b-cell repertoire towards a single b1 specificity with survival function. Immunol Rev. 2004;197:51-59

114. Rowley B, Tang L, Shinton S, Hayakawa K, Hardy RR. Autoreactive b-1 b cells: Constraints on natural autoantibody b cell antigen receptors. J Autoimmun. 2007;29:236-245 
115. Claflin JL, Cubberley M. Clonal nature of the immune response to phosphocholine. Vii. Evidence throughout inbred mice for molecular similarities among antibodies bearing the 15 idiotype. J Immunol. 1980;125:551-558

116. Shaw PX, Horkko S, Chang MK, Curtiss LK, Palinski W, Silverman GJ, Witztum JL. Natural antibodies with the $\mathrm{t} 15$ idiotype may act in atherosclerosis, apoptotic clearance, and protective immunity. J Clin Invest. 2000;105:17311740

117. Briles DE, Forman C, Hudak S, Claflin JL. Anti-phosphorylcholine antibodies of the 115 idiotype are optimally protective against streptococcus pneumoniae. J Exp Med. 1982;156:1177-1185

118. Mi QS, Zhou L, Schulze DH, Fischer RT, Lustig A, Rezanka LJ, Donovan DM, Longo DL, Kenny JJ. Highly reduced protection against streptococcus pneumoniae after deletion of a single heavy chain gene in mouse. Proc Natl Acad Sci U S A. 2000;97:6031-6036

119. Chen Y, Khanna S, Goodyear CS, Park YB, Raz E, Thiel S, Gronwall C, Vas J, Boyle DL, Corr M, Kono DH, Silverman GJ. Regulation of dendritic cells and macrophages by an anti-apoptotic cell natural antibody that suppresses tlr responses and inhibits inflammatory arthritis. J Immunol. 2009;183:13461359

120. Chen Y, Park YB, Patel E, Silverman GJ. Igm antibodies to apoptosisassociated determinants recruit c1q and enhance dendritic cell phagocytosis of apoptotic cells. J Immunol. 2009;182:6031-6043

121. Ehrenstein MR, Notley CA. The importance of natural igm: Scavenger, protector and regulator. Nat Rev Immunol. 2010;10:778-786

122. Gronwall C, Vas J, Silverman GJ. Protective roles of natural igm antibodies. Front Immunol. 2012;3:66

123. Ogden CA, Kowalewski R, Peng Y, Montenegro V, Elkon KB. Igm is required for efficient complement mediated phagocytosis of apoptotic cells in vivo. Autoimmunity. 2005;38:259-264

124. Quartier P, Potter PK, Ehrenstein MR, Walport MJ, Botto M. Predominant role of igm-dependent activation of the classical pathway in the clearance of dying cells by murine bone marrow-derived macrophages in vitro. Eur J Immunol. 2005;35:252-260

125. Silverman GJ. Regulatory natural autoantibodies to apoptotic cells: Pallbearers and protectors. Arthritis Rheum. 2011;63:597-602 
126. Munoz LE, Lauber K, Schiller M, Manfredi AA, Herrmann M. The role of defective clearance of apoptotic cells in systemic autoimmunity. Nat Rev Rheumatol. 2010;6:280-289

127. Nagata S, Hanayama R, Kawane K. Autoimmunity and the clearance of dead cells. Cell. 2010;140:619-630

128. Binder CJ, Chang MK, Shaw PX, Miller YI, Hartvigsen K, Dewan A, Witztum JL. Innate and acquired immunity in atherogenesis. Nat Med. 2002;8:1218-1226

129. Boes M, Schmidt T, Linkemann K, Beaudette BC, Marshak-Rothstein A, Chen J. Accelerated development of igg autoantibodies and autoimmune disease in the absence of secreted igm. Proc Natl Acad Sci U S A. 2000;97:1184-1189

130. Kyaw T, Tay C, Krishnamurthi S, Kanellakis P, Agrotis A, Tipping P, Bobik A, Toh BH. B1a b lymphocytes are atheroprotective by secreting natural igm that increases igm deposits and reduces necrotic cores in atherosclerotic lesions. Circ Res. 2011;109:830-840

131. Williams R, White $H$. The greater omentum: Its applicability to cancer surgery and cancer therapy. Curr Probl Surg. 1986;23:789-865

132. Platell C, Cooper D, Papadimitriou JM, Hall JC. The omentum. World J Gastroenterol. 2000;6:169-176

133. Shimotsuma M, Shields JW, Simpson-Morgan MW, Sakuyama A, Shirasu M, Hagiwara A, Takahashi T. Morpho-physiological function and role of omental milky spots as omentum-associated lymphoid tissue (oalt) in the peritoneal cavity. Lymphology. 1993;26:90-101

134. Harman-Boehm I, Bluher M, Redel H, Sion-Vardy N, Ovadia S, Avinoach E, Shai I, Kloting N, Stumvoll M, Bashan N, Rudich A. Macrophage infiltration into omental versus subcutaneous fat across different populations: Effect of regional adiposity and the comorbidities of obesity. J Clin Endocrinol Metab. 2007;92:2240-2247

135. Hardy OT, Perugini RA, Nicoloro SM, Gallagher-Dorval K, Puri V, Straubhaar J, Czech MP. Body mass index-independent inflammation in omental adipose tissue associated with insulin resistance in morbid obesity. Surg Obes Relat Dis. 2011;7:60-67

136. Kabir M, Catalano KJ, Ananthnarayan S, Kim SP, Van Citters GW, Dea MK, Bergman RN. Molecular evidence supporting the portal theory: A causative link between visceral adiposity and hepatic insulin resistance. Am J Physiol Endocrinol Metab. 2005;288:E454-461 
137. Catalano KJ, Stefanovski D, Bergman RN. Critical role of the mesenteric depot versus other intra-abdominal adipose depots in the development of insulin resistance in young rats. Diabetes. 2010;59:1416-1423

138. Rytka JM, Wueest S, Schoenle EJ, Konrad D. The portal theory supported by venous drainage-selective fat transplantation. Diabetes. 2011;60:56-63

139. Wilkosz S, Ireland G, Khwaja N, Walker M, Butt R, de Giorgio-Miller A, Herrick SE. A comparative study of the structure of human and murine greater omentum. Anat Embryol (Berl). 2005;209:251-261

140. von Recklinghausen F. Uber eiter-bindegewebskorperchen. Virchows Arch. Pathol. Anat. 1863;28:157-166

141. Krist LF, Eestermans IL, Steenbergen JJ, Hoefsmit EC, Cuesta MA, Meyer S, Beelen RH. Cellular composition of milky spots in the human greater omentum: An immunochemical and ultrastructural study. Anat Rec. 1995;241:163-174

142. Mebius RE. Lymphoid organs for peritoneal cavity immune response: Milky spots. Immunity. 2009;30:670-672

143. Moro K, Yamada T, Tanabe M, Takeuchi T, Ikawa T, Kawamoto H, Furusawa J, Ohtani M, Fujii H, Koyasu S. Innate production of $\mathrm{t}(\mathrm{h}) 2$ cytokines by adipose tissue-associated c-kit(+)sca-1(+) lymphoid cells. Nature. 2010;463:540-544

144. Massari ME, Murre C. Helix-loop-helix proteins: Regulators of transcription in eucaryotic organisms. Mol Cell Biol. 2000;20:429-440

145. Benezra R, Davis RL, Lockshon D, Turner DL, Weintraub H. The protein id: A negative regulator of helix-loop-helix DNA binding proteins. Cell. 1990;61:4959

146. Jen Y, Weintraub H, Benezra R. Overexpression of id protein inhibits the muscle differentiation program: In vivo association of id with e2a proteins. Genes Dev. 1992;6:1466-1479

147. Ruzinova MB, Benezra R. Id proteins in development, cell cycle and cancer. Trends Cell Biol. 2003;13:410-418

148. Norton JD, Deed RW, Craggs G, Sablitzky F. Id helix-loop-helix proteins in cell growth and differentiation. Trends Cell Biol. 1998;8:58-65

149. Lim RW, Wu JM. Molecular mechanisms regulating expression and function of transcription regulator inhibitor of differentiation 3. Acta Pharmacol Sin. 2005;26:1409-1420 
150. Christy BA, Sanders LK, Lau LF, Copeland NG, Jenkins NA, Nathans D. An idrelated helix-loop-helix protein encoded by a growth factor-inducible gene. Proc Natl Acad Sci U S A. 1991;88:1815-1819

151. Jen Y, Manova K, Benezra R. Expression patterns of id1, id2, and id3 are highly related but distinct from that of id4 during mouse embryogenesis. Dev Dyn. 1996;207:235-252

152. Ellmeier W, Weith A. Expression of the helix-loop-helix gene id3 during murine embryonic development. Dev Dyn. 1995;203:163-173

153. Engel I, Murre C. The function of e- and id proteins in lymphocyte development. Nat Rev Immunol. 2001;1:193-199

154. Sugai M, Gonda H, Nambu Y, Yokota Y, Shimizu A. Role of id proteins in b lymphocyte activation: New insights from knockout mouse studies. J Mol Med (Berl). 2004;82:592-599

155. Kee BL, Rivera RR, Murre C. Id3 inhibits b lymphocyte progenitor growth and survival in response to tgf-beta. Nat Immunol. 2001;2:242-247

156. Kee BL. Id3 induces growth arrest and caspase-2-dependent apoptosis in b lymphocyte progenitors. J Immunol. 2005;175:4518-4527

157. Thal MA, Carvalho TL, He T, Kim HG, Gao H, Hagman J, Klug CA. Ebf1mediated down-regulation of id2 and id3 is essential for specification of the $\mathrm{b}$ cell lineage. Proc Natl Acad Sci U S A. 2009;106:552-557

158. Pan L, Sato S, Frederick JP, Sun XH, Zhuang Y. Impaired immune responses and b-cell proliferation in mice lacking the id3 gene. Mol Cell Biol. 1999;19:5969-5980

159. Quong MW, Harris DP, Swain SL, Murre C. E2a activity is induced during bcell activation to promote immunoglobulin class switch recombination. EMBO J. 1999;18:6307-6318

160. Sayegh CE, Quong MW, Agata Y, Murre C. E-proteins directly regulate expression of activation-induced deaminase in mature b cells. Nat Immunol. 2003;4:586-593

161. Quong MW, Martensson A, Langerak AW, Rivera RR, Nemazee D, Murre C. Receptor editing and marginal zone $b$ cell development are regulated by the helix-loop-helix protein, e2a. J Exp Med. 2004;199:1101-1112

162. Doran AC, Lipinski MJ, Oldham SN, Garmey JC, Campbell KA, Skaflen MD, Cutchins A, Lee DJ, Glover DK, Kelly KA, Galkina EV, Ley K, Witztum JL, 
Tsimikas S, Bender TP, McNamara CA. B-cell aortic homing and atheroprotection depend on id3. Circ Res. 2012;110:e1-12

163. Hayakawa I, Tedder TF, Zhuang Y. B-lymphocyte depletion ameliorates sjogren's syndrome in id3 knockout mice. Immunology. 2007;122:73-79

164. Cutchins A, Harmon DB, Kirby JL, Doran AC, Oldham SN, Skaflen M, Klibanov AL, Meller N, Keller SR, Garmey J, McNamara CA. Inhibitor of differentiation-3 mediates high fat diet-induced visceral fat expansion. Arterioscler Thromb Vasc Biol. 2011

165. Li H, Dai M, Zhuang Y. A t cell intrinsic role of id3 in a mouse model for primary sjogren's syndrome. Immunity. 2004;21:551-560

166. Maruyama T, Li J, Vaque JP, Konkel JE, Wang W, Zhang B, Zhang P, Zamarron $\mathrm{BF}, \mathrm{Yu}$ D, Wu Y, Zhuang Y, Gutkind JS, Chen W. Control of the differentiation of regulatory t cells and $t(h) 17$ cells by the DNA-binding inhibitor id3. Nat Immunol. 2011;12:86-95

167. Miyazaki M, Rivera RR, Miyazaki K, Lin YC, Agata Y, Murre C. The opposing roles of the transcription factor e2a and its antagonist id3 that orchestrate and enforce the naive fate of $t$ cells. Nat Immunol. 2011;12:992-1001

168. Rivera RR, Johns CP, Quan J, Johnson RS, Murre C. Thymocyte selection is regulated by the helix-loop-helix inhibitor protein, id3. Immunity. 2000;12:17-26

169. Yang CY, Best JA, Knell J, Yang E, Sheridan AD, Jesionek AK, Li HS, Rivera RR, Lind KC, D'Cruz LM, Watowich SS, Murre C, Goldrath AW. The transcriptional regulators id 2 and id 3 control the formation of distinct memory cd8 $+t$ cell subsets. Nat Immunol. 2011;12:1221-1229

170. Guo Z, Li H, Han M, Xu T, Wu X, Zhuang Y. Modeling sjogren's syndrome with id3 conditional knockout mice. Immunol Lett. 2011;135:34-42

171. Perry HM, Oldham SN, Fahl SP, Que X, Gonen A, Harmon DB, Tsimikas S, Witztum JL, Bender TP, McNamara CA. Helix-loop-helix factor inhibitor of differentiation 3 regulates interleukin-5 expression and b-1a b cell proliferation. Arterioscler Thromb Vasc Biol. 2013;33:2771-2779

172. Carlow DA, Gold MR, Ziltener HJ. Lymphocytes in the peritoneum home to the omentum and are activated by resident dendritic cells. J Immunol. 2009;183:1155-1165

173. Zimmerlin L, Donnenberg VS, Donnenberg AD. Rare event detection and analysis in flow cytometry: Bone marrow mesenchymal stem cells, breast 
cancer stem/progenitor cells in malignant effusions, and pericytes in disaggregated adipose tissue. Methods Mol Biol. 2011;699:251-273

174. Fujisaka S, Usui I, Bukhari A, Ikutani M, Oya T, Kanatani Y, Tsuneyama K, Nagai Y, Takatsu K, Urakaze M, Kobayashi M, Tobe K. Regulatory mechanisms for adipose tissue $\mathrm{m} 1$ and $\mathrm{m} 2$ macrophages in diet-induced obese mice. Diabetes. 2009;58:2574-2582

175. Boes M, Esau C, Fischer MB, Schmidt T, Carroll M, Chen J. Enhanced b-1 cell development, but impaired igg antibody responses in mice deficient in secreted igm. J Immunol. 1998;160:4776-4787

176. Hansell CA, Schiering C, Kinstrie R, Ford L, Bordon Y, McInnes IB, Goodyear CS, Nibbs RJ. Universal expression and dual function of the atypical chemokine receptor d6 on innate-like b cells in mice. Blood. 2011;117:54135424

177. Ohdan H, Swenson KG, Kruger Gray HS, Yang YG, Xu Y, Thall AD, Sykes M. Mac-1-negative $b-1 b$ phenotype of natural antibody-producing cells, including those responding to gal alpha 1,3gal epitopes in alpha 1,3galactosyltransferase-deficient mice. J Immunol. 2000;165:5518-5529

178. Tsimikas S, Witztum JL, Miller ER, Sasiela WJ, Szarek M, Olsson AG, Schwartz GG. High-dose atorvastatin reduces total plasma levels of oxidized phospholipids and immune complexes present on apolipoprotein b-100 in patients with acute coronary syndromes in the miracl trial. Circulation. 2004;110:1406-1412

179. Ansel KM, Harris RB, Cyster JG. Cxcl13 is required for b1 cell homing, natural antibody production, and body cavity immunity. Immunity. 2002;16:67-76

180. Tarlinton D. B-cell memory: Are subsets necessary? Nat Rev Immunol. 2006;6:785-790

181. Rajewsky K. Clonal selection and learning in the antibody system. Nature. 1996;381:751-758

182. Baumgarth N, Tung JW, Herzenberg LA. Inherent specificities in natural antibodies: A key to immune defense against pathogen invasion. Springer Semin Immunopathol. 2005;26:347-362

183. Binder CJ. Natural igm antibodies against oxidation-specific epitopes. J Clin Immunol. 2010;30 Suppl 1:S56-60

184. Binder CJ, Horkko S, Dewan A, Chang MK, Kieu EP, Goodyear CS, Shaw PX, Palinski W, Witztum JL, Silverman GJ. Pneumococcal vaccination decreases 
atherosclerotic lesion formation: Molecular mimicry between streptococcus pneumoniae and oxidized ldl. Nat Med. 2003;9:736-743

185. Horkko S, Bird DA, Miller E, Itabe H, Leitinger N, Subbanagounder G, Berliner JA, Friedman P, Dennis EA, Curtiss LK, Palinski W, Witztum JL. Monoclonal autoantibodies specific for oxidized phospholipids or oxidized phospholipidprotein adducts inhibit macrophage uptake of oxidized low-density lipoproteins. J Clin Invest. 1999;103:117-128

186. Lipinski MJ, Campbell KA, Duong SQ, Welch TJ, Garmey JC, Doran AC, Skaflen MD, Oldham SN, Kelly KA, McNamara CA. Loss of id3 increases vcam-1 expression, macrophage accumulation, and atherogenesis in ldlr-/- mice. Arterioscler Thromb Vasc Biol. 2012;32:2855-2861

187. Kitamura D, Roes J, Kuhn R, Rajewsky K. A b cell-deficient mouse by targeted disruption of the membrane exon of the immunoglobulin mu chain gene. Nature. 1991;350:423-426

188. Baumgarth N, Jager GC, Herman OC, Herzenberg LA. Cd4+ t cells derived from b cell-deficient mice inhibit the establishment of peripheral b cell pools. Proc Natl Acad Sci U S A. 2000;97:4766-4771

189. Genestier L, Taillardet M, Mondiere P, Gheit H, Bella C, Defrance T. Tlr agonists selectively promote terminal plasma cell differentiation of $\mathrm{b}$ cell subsets specialized in thymus-independent responses. J Immunol. 2007;178:7779-7786

190. Murano I, Barbatelli G, Parisani V, Latini C, Muzzonigro G, Castellucci M, Cinti $\mathrm{S}$. Dead adipocytes, detected as crown-like structures, are prevalent in visceral fat depots of genetically obese mice. J Lipid Res. 2008;49:1562-1568

191. Cinti S, Mitchell G, Barbatelli G, Murano I, Ceresi E, Faloia E, Wang S, Fortier M, Greenberg AS, Obin MS. Adipocyte death defines macrophage localization and function in adipose tissue of obese mice and humans. J Lipid Res. 2005;46:2347-2355

192. Khokher MA, Woods RJ, Dandona P. Human immunoglobulin m stimulates adipocyte lipogenesis. Metabolism. 1984;33:208-211

193. Khokher MA, Dandona P, Janah S, Coulston GL. Insulin-like stimulatory effect of human immunoglobulin g on adipocyte lipogenesis. Diabetes. 1981;30:1068-1071

194. Dux K, Rouse RV, Kyewski B. Composition of the lymphoid cell populations from omental milky spots during the immune response in c57bl/ka mice. Eur J Immunol. 1986;16:1029-1032 
195. Ibrahim MM. Subcutaneous and visceral adipose tissue: Structural and functional differences. Obes Rev. 2010;11:11-18

196. Fontana L, Eagon JC, Trujillo ME, Scherer PE, Klein S. Visceral fat adipokine secretion is associated with systemic inflammation in obese humans. Diabetes. 2007;56:1010-1013

197. Haley PJ. Species differences in the structure and function of the immune system. Toxicology. 2003;188:49-71

198. Kaminski DA, Wei C, Qian Y, Rosenberg AF, Sanz I. Advances in human b cell phenotypic profiling. Front Immunol. 2012;3:302

199. Mestas J, Hughes CC. Of mice and not men: Differences between mouse and human immunology. J Immunol. 2004;172:2731-2738

200. Tsimikas S, Brilakis ES, Lennon RJ, Miller ER, Witztum JL, McConnell JP, Kornman KS, Berger PB. Relationship of igg and igm autoantibodies to oxidized low density lipoprotein with coronary artery disease and cardiovascular events. J Lipid Res. 2007;48:425-433

201. Sjoberg BG, Su J, Dahlbom I, Gronlund H, Wikstrom M, Hedblad B, Berglund G, de Faire U, Frostegard J. Low levels of igm antibodies against phosphorylcholine-a potential risk marker for ischemic stroke in men. Atherosclerosis. 2009;203:528-532

202. Su J, Georgiades A, Wu R, Thulin T, de Faire U, Frostegard J. Antibodies of igm subclass to phosphorylcholine and oxidized ldl are protective factors for atherosclerosis in patients with hypertension. Atherosclerosis. 2006;188:160166

203. Gronwall C, Akhter E, Oh C, Burlingame RW, Petri M, Silverman GJ. Igm autoantibodies to distinct apoptosis-associated antigens correlate with protection from cardiovascular events and renal disease in patients with sle. Clin Immunol. 2012;142:390-398

204. Senaldi G, Ireland R, Bellingham AJ, Vergani D, Veerapan K, Wang F. Igm reduction in systemic lupus erythematosus. Arthritis Rheum. 1988;31:1213

205. Tsimikas S, Willeit P, Willeit J, Santer P, Mayr M, Xu Q, Mayr A, Witztum JL, Kiechl S. Oxidation-specific biomarkers, prospective 15-year cardiovascular and stroke outcomes, and net reclassification of cardiovascular events. J Am Coll Cardiol. 2012;60:2218-2229

206. Mehrani T, Petri M. Igm anti-beta2 glycoprotein i is protective against lupus nephritis and renal damage in systemic lupus erythematosus. The Journal of rheumatology. 2011;38:450-453 
207. Witte T, Hartung K, Sachse C, Matthias T, Fricke M, Deicher H, Kalden JR, Lakomek HJ, Peter HH, Schmidt RE. Igm anti-dsdna antibodies in systemic lupus erythematosus: Negative association with nephritis. Sle study group. Rheumatol Int. 1998;18:85-91

208. Lutz HU, Binder CJ, Kaveri S. Naturally occurring auto-antibodies in homeostasis and disease. Trends Immunol. 2009;30:43-51

209. Matthews DR, Hosker JP, Rudenski AS, Naylor BA, Treacher DF, Turner RC. Homeostasis model assessment: Insulin resistance and beta-cell function from fasting plasma glucose and insulin concentrations in man. Diabetologia. $1985 ; 28: 412-419$

210. Goff DC, Jr., D'Agostino RB, Jr., Haffner SM, Otvos JD. Insulin resistance and adiposity influence lipoprotein size and subclass concentrations. Results from the insulin resistance atherosclerosis study. Metabolism. 2005;54:264270

211. Garvey WT, Kwon S, Zheng D, Shaughnessy S, Wallace P, Hutto A, Pugh K, Jenkins AJ, Klein RL, Liao Y. Effects of insulin resistance and type 2 diabetes on lipoprotein subclass particle size and concentration determined by nuclear magnetic resonance. Diabetes. 2003;52:453-462

212. Mora S, Otvos JD, Rosenson RS, Pradhan A, Buring JE, Ridker PM. Lipoprotein particle size and concentration by nuclear magnetic resonance and incident type 2 diabetes in women. Diabetes. 2010;59:1153-1160

213. Rivellese AA, Patti L, Kaufman D, Zhu J, Annuzzi G, Vaccaro O, Ebbesson SO, Howard WJ, Riccardi G, Howard BV. Lipoprotein particle distribution and size, insulin resistance, and metabolic syndrome in alaska eskimos: The gocadan study. Atherosclerosis. 2008;200:350-358

214. Li W, Batliwalla F, Rothstein TL. Human b-1 cells are not preplasmablasts: Analysis of microarray data and other issues. Blood. 2013;122:3691-3693

215. Covens K, Verbinnen B, Jacquemin M, Bossuyt X. Response: Extended analysis of microarray data does not contradict preplasmablast phenotype of human cd20+cd27+cd43+ cells. Blood. 2013;122:3693-3694

216. Covens K, Verbinnen B, Geukens N, Meyts I, Schuit F, Van Lommel L, Jacquemin M, Bossuyt X. Characterization of proposed human b-1 cells reveals pre-plasmablast phenotype. Blood. 2013;121:5176-5183

217. Barber CL, Montecino-Rodriguez E, Dorshkind K. Reduced production of b-1specified common lymphoid progenitors results in diminished potential of adult marrow to generate b-1 cells. Proc Natl Acad Sci U S A.

2011;108:13700-13704 
218. Simeoni E, Hoffmann MM, Winkelmann BR, Ruiz J, Fleury S, Boehm BO, Marz $\mathrm{W}$, Vassalli G. Association between the a-2518g polymorphism in the monocyte chemoattractant protein-1 gene and insulin resistance and type 2 diabetes mellitus. Diabetologia. 2004;47:1574-1580

219. Kanda H, Tateya S, Tamori Y, Kotani K, Hiasa K, Kitazawa R, Kitazawa S, Miyachi H, Maeda S, Egashira K, Kasuga M. Mcp-1 contributes to macrophage infiltration into adipose tissue, insulin resistance, and hepatic steatosis in obesity. J Clin Invest. 2006;116:1494-1505

220. Perry HM, Bender TP, McNamara CA. B cell subsets in atherosclerosis. Front Immunol. 2012;3:373

221. Yang H, Youm YH, Vandanmagsar B, Ravussin A, Gimble JM, Greenway F, Stephens JM, Mynatt RL, Dixit VD. Obesity increases the production of proinflammatory mediators from adipose tissue $t$ cells and compromises tcr repertoire diversity: Implications for systemic inflammation and insulin resistance. J Immunol. 2010;185:1836-1845

222. Morris DL, Cho KW, Delproposto JL, Oatmen KE, Geletka LM, MartinezSantibanez G, Singer K, Lumeng CN. Adipose tissue macrophages function as antigen-presenting cells and regulate adipose tissue cd4+ $t$ cells in mice. Diabetes. 2013;62:2762-2772

223. Alugupalli KR. A distinct role for b1b lymphocytes in t cell-independent immunity. Curr Top Microbiol Immunol. 2008;319:105-130

224. Park-Min KH, Antoniv TT, Ivashkiv LB. Regulation of macrophage phenotype by long-term exposure to il-10. Immunobiology. 2005;210:77-86

225. Lumeng CN, Bodzin JL, Saltiel AR. Obesity induces a phenotypic switch in adipose tissue macrophage polarization. J Clin Invest. 2007;117:175-184

226. Hsu MC, Toellner KM, Vinuesa CG, Maclennan IC. B cell clones that sustain long-term plasmablast growth in t-independent extrafollicular antibody responses. Proc Natl Acad Sci U S A. 2006;103:5905-5910

227. Ghosn EE, Yamamoto R, Hamanaka S, Yang Y, Herzenberg LA, Nakauchi H. Distinct b-cell lineage commitment distinguishes adult bone marrow hematopoietic stem cells. Proc Natl Acad Sci U S A. 2012;109:5394-5398

228. Montecino-Rodriguez E, Leathers H, Dorshkind K. Identification of a b-1 b cell-specified progenitor. Nat Immunol. 2006;7:293-301

229. Martin F, Kearney JF. B1 cells: Similarities and differences with other b cell subsets. Curr Opin Immunol. 2001;13:195-201 
230. Alugupalli KR, Gerstein RM, Chen J, Szomolanyi-Tsuda E, Woodland RT, Leong JM. The resolution of relapsing fever borreliosis requires igm and is concurrent with expansion of b1b lymphocytes. J Immunol. 2003;170:38193827

231. Kantor AB, Merrill CE, Herzenberg LA, Hillson JL. An unbiased analysis of $\mathrm{v}(\mathrm{h})$-d-j(h) sequences from b-1a, b-1b, and conventional b cells. J Immunol. 1997;158:1175-1186

232. Tornberg UC, Holmberg D. B-1a, b-1b and b-2 b cells display unique vhdjh repertoires formed at different stages of ontogeny and under different selection pressures. EMBO J. 1995;14:1680-1689

233. Toellner KM, Jenkinson WE, Taylor DR, Khan M, Sze DM, Sansom DM, Vinuesa CG, MacLennan IC. Low-level hypermutation in $t$ cell-independent germinal centers compared with high mutation rates associated with t cell-dependent germinal centers. J Exp Med. 2002;195:383-389

234. DeKosky BJ, Ippolito GC, Deschner RP, Lavinder JJ, Wine Y, Rawlings BM, Varadarajan N, Giesecke C, Dorner T, Andrews SF, Wilson PC, Hunicke-Smith SP, Willson CG, Ellington AD, Georgiou G. High-throughput sequencing of the paired human immunoglobulin heavy and light chain repertoire. Nature biotechnology. 2013;31:166-169

235. Van Vugt E, Van Rijthoven EA, Kamperdijk EW, Beelen RH. Omental milky spots in the local immune response in the peritoneal cavity of rats. Anat Rec. 1996;244:235-245

236. Cui L, Johkura K, Liang Y, Teng R, Ogiwara N, Okouchi Y, Asanuma K, Sasaki K. Biodefense function of omental milky spots through cell adhesion molecules and leukocyte proliferation. Cell Tissue Res. 2002;310:321-330

237. Gerber SA, Rybalko VY, Bigelow CE, Lugade AA, Foster TH, Frelinger JG, Lord EM. Preferential attachment of peritoneal tumor metastases to omental immune aggregates and possible role of a unique vascular microenvironment in metastatic survival and growth. Am J Pathol. 2006;169:1739-1752

238. Hodel C. Ultrastructural studies on the absorption of protein markers by the greater omentum. European surgical research. Europaische chirurgische Forschung. Recherches chirurgicales europeennes. 1970;2:435-449

239. Beck K, Peak MM, Ota T, Nemazee D, Murre C. Distinct roles for e12 and e47 in $\mathrm{b}$ cell specification and the sequential rearrangement of immunoglobulin light chain loci. J Exp Med. 2009;206:2271-2284 
240. Hauser J, Verma-Gaur J, Wallenius A, Grundstrom T. Initiation of antigen receptor-dependent differentiation into plasma cells by calmodulin inhibition of e2a. J Immunol. 2009;183:1179-1187

241. Bandura DR, Baranov VI, Ornatsky OI, Antonov A, Kinach R, Lou X, Pavlov S, Vorobiev S, Dick JE, Tanner SD. Mass cytometry: Technique for real time single cell multitarget immunoassay based on inductively coupled plasma time-of-flight mass spectrometry. Anal Chem. 2009;81:6813-6822

242. Karras JG, Wang Z, Huo L, Howard RG, Frank DA, Rothstein TL. Signal transducer and activator of transcription-3 (stat3) is constitutively activated in normal, self-renewing b-1 cells but only inducibly expressed in conventional b lymphocytes. J Exp Med. 1997;185:1035-1042

243. Holodick NE, Tumang JR, Rothstein TL. Continual signaling is responsible for constitutive erk phosphorylation in b-1a cells. Mol Immunol. 2009;46:30293036

244. Wong SC, Chew WK, Tan JE, Melendez AJ, Francis F, Lam KP. Peritoneal cd5+ b-1 cells have signaling properties similar to tolerant b cells. J Biol Chem. 2002;277:30707-30715

245. O'Shea JJ, Gadina M, Schreiber RD. Cytokine signaling in 2002: New surprises in the jak/stat pathway. Cell. 2002;109 Suppl:S121-131

246. Lu Z, Xu S. Erk1/2 map kinases in cell survival and apoptosis. IUBMB life. 2006;58:621-631

247. Bain G, Cravatt CB, Loomans C, Alberola-Ila J, Hedrick SM, Murre C. Regulation of the helix-loop-helix proteins, e2a and id3, by the ras-erk mapk cascade. Nat Immunol. 2001;2:165-171

248. Sugai M, Gonda H, Kusunoki T, Katakai T, Yokota Y, Shimizu A. Essential role of id2 in negative regulation of ige class switching. Nat Immunol. 2003;4:2530

249. Ravichandran KS. Find-me and eat-me signals in apoptotic cell clearance: Progress and conundrums. J Exp Med. 2010;207:1807-1817

250. Gabriel CL, Smith PB, Mendez-Fernandez YV, Wilhelm AJ, Ye AM, Major AS. Autoimmune-mediated glucose intolerance in a mouse model of systemic lupus erythematosus. Am J Physiol Endocrinol Metab. 2012;303:E1313-1324

251. Ryan MJ, McLemore GR, Jr., Hendrix ST. Insulin resistance and obesity in a mouse model of systemic lupus erythematosus. Hypertension. 2006;48:988993 
252. El Magadmi M, Ahmad Y, Turkie W, Yates AP, Sheikh N, Bernstein RM, Durrington PN, Laing I, Bruce IN. Hyperinsulinemia, insulin resistance, and circulating oxidized low density lipoprotein in women with systemic lupus erythematosus. The Journal of rheumatology. 2006;33:50-56

253. Ehrenstein MR, Cook HT, Neuberger MS. Deficiency in serum immunoglobulin (ig)m predisposes to development of igg autoantibodies. $J$ Exp Med. 2000;191:1253-1258

254. Peng Y, Kowalewski R, Kim S, Elkon KB. The role of igm antibodies in the recognition and clearance of apoptotic cells. Mol Immunol. 2005;42:781-787

255. Chang MK, Bergmark C, Laurila A, Horkko S, Han KH, Friedman P, Dennis EA, Witztum JL. Monoclonal antibodies against oxidized low-density lipoprotein bind to apoptotic cells and inhibit their phagocytosis by elicited macrophages: Evidence that oxidation-specific epitopes mediate macrophage recognition. Proc Natl Acad Sci U S A. 1999;96:6353-6358

256. Korb LC, Ahearn JM. C1q binds directly and specifically to surface blebs of apoptotic human keratinocytes: Complement deficiency and systemic lupus erythematosus revisited. J Immunol. 1997;158:4525-4528

257. Botto M, Dell'Agnola C, Bygrave AE, Thompson EM, Cook HT, Petry F, Loos M, Pandolfi PP, Walport MJ. Homozygous c1q deficiency causes glomerulonephritis associated with multiple apoptotic bodies. Nature genetics. 1998;19:56-59

258. Ogden CA, deCathelineau A, Hoffmann PR, Bratton D, Ghebrehiwet B, Fadok VA, Henson PM. C1q and mannose binding lectin engagement of cell surface calreticulin and cd91 initiates macropinocytosis and uptake of apoptotic cells. J Exp Med. 2001;194:781-795

259. Stuart LM, Takahashi K, Shi L, Savill J, Ezekowitz RA. Mannose-binding lectindeficient mice display defective apoptotic cell clearance but no autoimmune phenotype. J Immunol. 2005;174:3220-3226

260. Cocca BA, Seal SN, D'Agnillo P, Mueller YM, Katsikis PD, Rauch J, Weigert M, Radic MZ. Structural basis for autoantibody recognition of phosphatidylserine-beta 2 glycoprotein i and apoptotic cells. Proc Natl Acad Sci U S A. 2001;98:13826-13831

261. Wellmann U, Letz M, Herrmann M, Angermuller S, Kalden JR, Winkler TH. The evolution of human anti-double-stranded DNA autoantibodies. Proc Natl Acad Sci U S A. 2005;102:9258-9263

262. Sorice M, Pittoni V, Griggi T, Losardo A, Leri O, Magno MS, Misasi R, Valesini G. Specificity of anti-phospholipid antibodies in infectious mononucleosis: A 
role for anti-cofactor protein antibodies. Clin Exp Immunol. 2000;120:301306

263. Tuominen A, Miller YI, Hansen LF, Kesaniemi YA, Witztum JL, Horkko S. A natural antibody to oxidized cardiolipin binds to oxidized low-density lipoprotein, apoptotic cells, and atherosclerotic lesions. Arterioscler Thromb Vasc Biol. 2006;26:2096-2102

264. Fu M, Fan PS, Li W, Li CX, Xing Y, An JG, Wang G, Fan XL, Gao TW, Liu YF, Ikeda $S$. Identification of poly-reactive natural igm antibody that recognizes late apoptotic cells and promotes phagocytosis of the cells. Apoptosis : an international journal on programmed cell death. 2007;12:355-362

265. Kulik L, Fleming SD, Moratz C, Reuter JW, Novikov A, Chen K, Andrews KA, Markaryan A, Quigg RJ, Silverman GJ, Tsokos GC, Holers VM. Pathogenic natural antibodies recognizing annexin iv are required to develop intestinal ischemia-reperfusion injury. J Immunol. 2009;182:5363-5373

266. Kim J. Identification of a human monoclonal natural igm antibody that recognizes early apoptotic cells and promotes phagocytosis. Hybridoma (Larchmt). 2010;29:275-281

267. Alkhouri N, Gornicka A, Berk MP, Thapaliya S, Dixon LJ, Kashyap S, Schauer PR, Feldstein AE. Adipocyte apoptosis, a link between obesity, insulin resistance, and hepatic steatosis. J Biol Chem. 2010;285:3428-3438

268. Fernandez-Real JM, Straczkowski M, Vendrell J, Soriguer F, Perez Del Pulgar S, Gallart L, Lopez-Bermejo A, Kowalska I, Manco M, Cardona F, Garcia-Gil MM, Mingrone G, Richart C, Ricart W, Zorzano A. Protection from inflammatory disease in insulin resistance: The role of mannan-binding lectin. Diabetologia. 2006;49:2402-2411

269. Megia A, Gallart L, Fernandez-Real JM, Vendrell J, Simon I, Gutierrez C, Richart C. Mannose-binding lectin gene polymorphisms are associated with gestational diabetes mellitus. J Clin Endocrinol Metab. 2004;89:5081-5087

270. Strissel KJ, Stancheva Z, Miyoshi H, Perfield JW, 2nd, DeFuria J, Jick Z, Greenberg AS, Obin MS. Adipocyte death, adipose tissue remodeling, and obesity complications. Diabetes. 2007;56:2910-2918

271. Wueest S, Rapold RA, Schumann DM, Rytka JM, Schildknecht A, Nov O, Chervonsky AV, Rudich A, Schoenle EJ, Donath MY, Konrad D. Deletion of fas in adipocytes relieves adipose tissue inflammation and hepatic manifestations of obesity in mice. J Clin Invest. 2010;120:191-202 
272. Herold C, Rennekampff HO, Engeli S. Apoptotic pathways in adipose tissue. Apoptosis : an international journal on programmed cell death. 2013;18:911916

273. Bird DA, Gillotte KL, Horkko S, Friedman P, Dennis EA, Witztum JL, Steinberg D. Receptors for oxidized low-density lipoprotein on elicited mouse peritoneal macrophages can recognize both the modified lipid moieties and the modified protein moieties: Implications with respect to macrophage recognition of apoptotic cells. Proc Natl Acad Sci U S A. 1999;96:6347-6352

274. Imai Y, Kuba K, Neely GG, Yaghubian-Malhami R, Perkmann T, van Loo G, Ermolaeva M, Veldhuizen R, Leung YH, Wang H, Liu H, Sun Y, Pasparakis M, Kopf M, Mech C, Bavari S, Peiris JS, Slutsky AS, Akira S, Hultqvist M, Holmdahl $\mathrm{R}$, Nicholls J, Jiang C, Binder CJ, Penninger JM. Identification of oxidative stress and toll-like receptor 4 signaling as a key pathway of acute lung injury. Cell. 2008;133:235-249

275. Hitoshi Y, Lorens J, Kitada SI, Fisher J, LaBarge M, Ring HZ, Francke U, Reed JC, Kinoshita S, Nolan GP. Toso, a cell surface, specific regulator of fas-induced apoptosis in t cells. Immunity. 1998;8:461-471

276. Kubagawa H, Oka S, Kubagawa Y, Torii I, Takayama E, Kang DW, Gartland GL, Bertoli LF, Mori H, Takatsu H, Kitamura T, Ohno H, Wang JY. Identity of the elusive igm fc receptor (fcmur) in humans. J Exp Med. 2009;206:2779-2793

277. Shima H, Takatsu H, Fukuda S, Ohmae M, Hase K, Kubagawa H, Wang JY, Ohno $\mathrm{H}$. Identification of toso/faim3 as an fc receptor for igm. Int Immunol. 2010;22:149-156

278. Lang KS, Lang PA, Meryk A, Pandyra AA, Boucher LM, Pozdeev VI, Tusche MW, Gothert JR, Haight J, Wakeham A, You-Ten AJ, Mcllwain DR, Merches K, Khairnar V, Recher M, Nolan GP, Hitoshi Y, Funkner P, Navarini AA, Verschoor A, Shaabani N, Honke N, Penn LZ, Ohashi PS, Haussinger D, Lee KH, Mak TW. Involvement of toso in activation of monocytes, macrophages, and granulocytes. Proc Natl Acad Sci U S A. 2013;110:2593-2598

279. Khokher MA, Dandona P. Stimulatory effect of immunoglobulins and fc fragments on glucose oxidation and glucose transport by adipocytes. British journal of experimental pathology. 1985;66:129-135

280. Khokher MA, Dandona P. Insulin-like stimulatory effect of fc fragments of human immunoglobulin g on rat adipocyte lipogenesis: Indirect evidence for fc receptor on adipocytes. J Clin Endocrinol Metab. 1983;56:393-396

281. Hayakawa K, Hardy RR, Parks DR, Herzenberg LA. The "ly-1 b" cell subpopulation in normal immunodefective, and autoimmune mice.J Exp Med. 1983;157:202-218 
282. Kantor AB, Herzenberg LA. Origin of murine b cell lineages. Annu Rev Immunol. 1993;11:501-538

283. Casali P, Notkins AL. Probing the human b-cell repertoire with ebv: Polyreactive antibodies and cd5+ b lymphocytes. Annu Rev Immunol. 1989;7:513-535

284. Kasaian MT, Ikematsu H, Casali P. Identification and analysis of a novel human surface cd5- b lymphocyte subset producing natural antibodies. $J$ Immunol. 1992;148:2690-2702

285. Sims GP, Ettinger R, Shirota Y, Yarboro CH, Illei GG, Lipsky PE. Identification and characterization of circulating human transitional b cells. Blood. $2005 ; 105: 4390-4398$

286. Cuss AK, Avery DT, Cannons JL, Yu LJ, Nichols KE, Shaw PJ, Tangye SG. Expansion of functionally immature transitional $\mathrm{b}$ cells is associated with human-immunodeficient states characterized by impaired humoral immunity. J Immunol. 2006;176:1506-1516

287. Marzullo P, Minocci A, Giarda P, Marconi C, Tagliaferri A, Walker GE, Scacchi M, Aimaretti G, Liuzzi A. Lymphocytes and immunoglobulin patterns across the threshold of severe obesity. Endocrine. 2014;45:392-400 